Portland State University

PDXScholar

$1-1-1975$

\title{
Marx on population: a critical review including a comparison to Malthus and a new perspective on
} Marx

David Orval Jermain

Portland State University

Follow this and additional works at: https://pdxscholar.library.pdx.edu/open_access_etds Let us know how access to this document benefits you.

\section{Recommended Citation}

Jermain, David Orval, "Marx on population: a critical review including a comparison to Malthus and a new perspective on Marx" (1975). Dissertations and Theses. Paper 823.

https://doi.org/10.15760/etd.823

This Thesis is brought to you for free and open access. It has been accepted for inclusion in Dissertations and Theses by an authorized administrator of PDXScholar. Please contact us if we can make this document more accessible: pdxscholar@pdx.edu. 


\title{
MARX ON POPULATION: A CRITICAL REVIEW \\ INCLUDING A COMPARISON TO MALTHUS \\ AND A NEW PERSPECTTVE ON MARX
}

\author{
by \\ DAVID ORVAI JERMAIN
}
A thesis submitted in partial fulfillment of the requirements for the degree of

\author{
MASTER OF SCIENCE \\ in \\ SOCIOLOGY
}

\author{
Portland State University \\ 1975 \\ (c) David Orval Jermain 1975
}


TO THE OFFICE OF GRADUATE STUDIES AND RESPARCH:

The members of the Committee approre the thesis of

David Orval Jermain presented July 21, 1975.
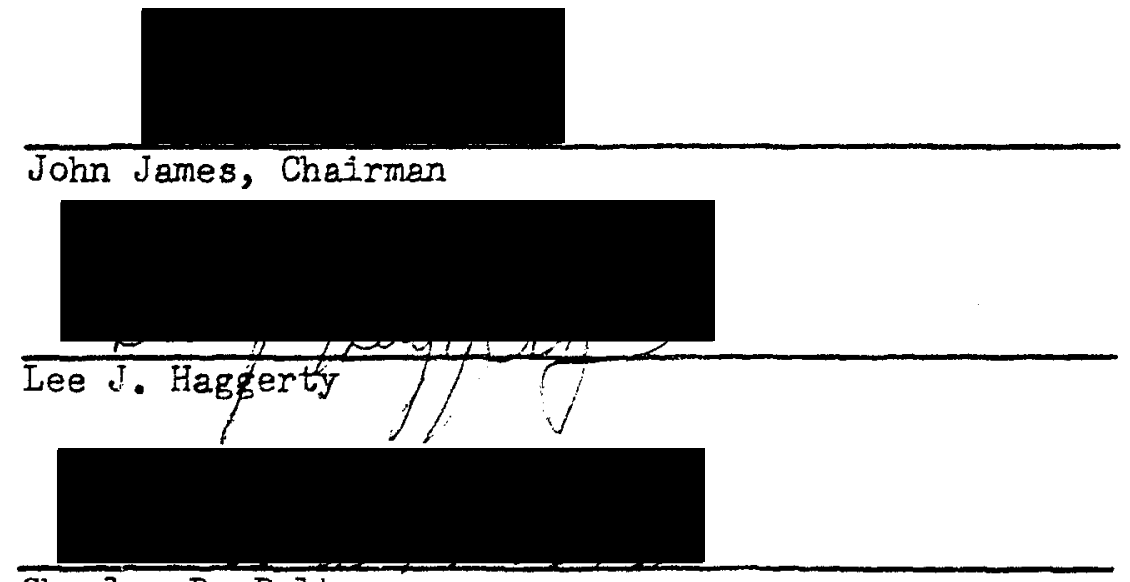

Charles D. Bolton

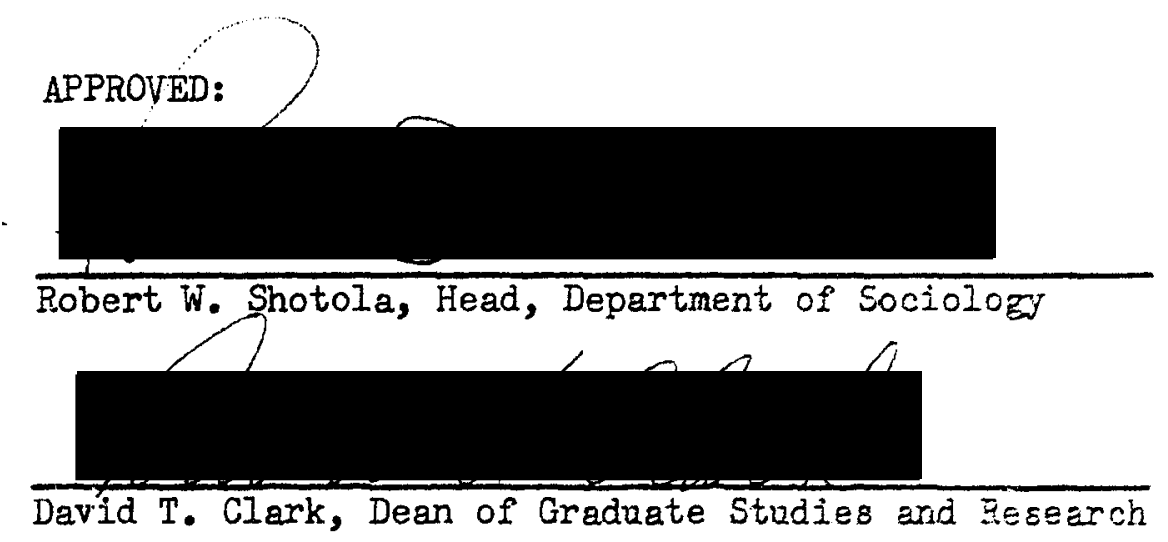

August 13, 1975 
AN ABSTRACT OF THE THESIS OF David Orval Jermain for the Master of Science in Sociology presented. July 21, 1975.

Title: Marx on Population: A Critical Review Including a Comparison to Malthus and a New Perspective on Marx.

A critical review of Marx on population is made to determine if the modern Marxist population theory can validly claim to follow from Marx. An historical review of population thought from the Greeks to Malthus is made and a dominant trendline is identified. Marx's population thought is presented and it is compared to Malthus. Anomalies in Marx are discovered. A new perspective on Marx using the history of demography is advanced in which Malthus is found deviating from the dominant trendline and Marx's criticism of Malthus as focusing on these specific points of deviation. Marx is found defending the dominant trendline against Malthus and not as advancing an original theory of population. Remaining problems with Marx are noted. The conclusion rejects the modern Marxist claim. 


\section{ACKNOWLEDGEMENTS}

The importance of making acknowledgements is especially great when the written document is a thesis. First, it is usually the initial experience at writing requiring an extended time period and great concentrated study of a single subject for the writer. Second, it is a document developed under the watchful eyes of many individuals. The result is a long struggle for the writer that is quite intensive work. While for this writer the experience was thrilling and enjoyed greatly, it nevertheless was an experience whose greatest joy is having it a thing of the past. Indeed, the euphoria that comes with completion of the work is tremendous; a quite unique feeling. In the wake of this euphoria comes the inclination to overdo on the acknowledgements and thank everyone in sight, including the maker of the typewriter, even the paper used for accepting the print made by the typewriter. After realizing this euphoria has stretched the bounds of rational necessity well beyond realism, a control is developed and the important effort at identifying those who were really important aides and comrades begins. For me, this task has led to the realization that there are some who are so important that a satisfactory acknowledgement seems impossible to write. There seems a small challenge to creativity to find a way to convey adequately appreciation for them without lapsing into euphoria that is pretentious and boring. Giving this matter lengthy thought, the following expressions of appreciation have been distilled from the effort. Any writer knows that writing is more than just assembling words 
into sentences. Beneath the actual creative effort rests a social

foundation of great significance. For me, this foundation was composed of individuals who helped me sustain my momentum over the 14 months it took to write this thesis. My momentum was sustained through inspiration, encouragement, interest, and confidence provided by others. Several individuals must be thanked.

Charles Horton Cooley wrote in Human Nature and the Social Order, (New York: Schocken Books, 1964), pp. 312-14, that hero-worship was the striving to imitate some admired character, "in a spirit not of rivalry or opposition, but of loyal enthusiasm." Cooley says further of heroworship,

It is higher than rivalry, the sense that it involves a superior grade of mental activity-though, of course, there is no sharp line of separation between them. While the other is a rather gross and simple impulse, common to all men and to the higher animals, the hero-worshipper is an idealist, imaginative; the object that arouses his enthusiasm and his endeavor does so because it bears a certain relation to his aspirations, to his constructive thought. Hero-worship is thus selective, more significant of the special character and tendencies of the individual, in every way more highly organized than rivalry.

It has a great place in all active, aspiring lives, espe= cially in the plastic period of youth. We feed our characters, while they are forming, upon the vision of admired models; an ardent sympathy dwells upon the traits through which their personality is communicated to us-facial expression, voice, significant movements, and so on. In this way, those tendencies in us that are toward them are literally fed; are stimulated, organized, made habitual and familiar. As already pointed out, sympathy appears to be an act of growth; and this is especially true of the sort of sympathy we call hero-worship. All autobiographies which deal with youth show that the early development of character is through a series of admirations and enthusiasms, which pass away, to be sure, but leave character the richer for their existence....

For me, Cooley admirably expresses my appreciation for Dr. John James. This expression of my appreciation is important to make because 
of the extraordinary influence (and importance) Dr. James has played for the last seven years in my intellectual development as an undergraduate and graduate student. Dr. James had confidence in me where others did not. He has always inspired me, encouraged me, maintained a serious interest in my work as a student and my character development as a person. He is a great thinker in my view, and I consider him an excelient role-model for my academic pursuits. In short, he is a real academic hero for me. I feel it would be entirely insufficient to just thank him for his help and guidance in writing this thesis for this thesis is really the culmination of a long working association with him as student-to-teacher. Thus, to acknowledge his help requires acknowledgement of his importance in the academic development of this stadent up to the present. I believe I have had the rare fortune of studying under a great creative thinker who is ahead of his time. His influence shall affect my study throughout my life. I think I have had a rare study opportunity in my academic relation to $\mathrm{Dr}$. James which deserves this recognition and expression of appreciation.

However, the great importance Dr. James has played in my development is not the only influence on me. I consider Dr. Lee J. Haggerty to be a great influence on me as well. Lee Haggerty has played an important and influential role in the development of this study by acting as a resource person. However, this is not all he did. He has been a source of encouragement and stimulation simply by being available to discuss ideas, share insights, provide critical comments which helped guide me as I was trying to shape this study into a format, an argument, a structure. In many ways, Lee Haggerty is an academic hero 
of mine as well. Cooley's words can be applied here as well. Lee Haggerty is an intellectually exciting person to be around. I thank him for his help.

Dr. Charles Bolton merits special thanks. First, he was willing to be a member of my committee when a heavy work schedule made such a role difficult. Second, his editorial comments, suggestions, and critical observations were very helpful in the formulation of the final draft. I enjoyed the experience of his critical eye; I thank him for his insight.

A long time friend and intellectual sparring partner needs to be acknowledged. Robert $R$. Schmaling helped in many ways. He was available most all the time to provide instant feedback for small and large problems. His criticism, and suggestions, saved me many times from throwing in the towel over what appeared an insurmountable roadblock here and there. If every student had such an aide and commrade thesis writing would be easy for everyone.

The library staff occupying the chairs at the information desk were most helpful. In particular, I thank Iibrarian Majel Michel Warren who was especially helpful.

Finally, for emotional and financial support, thanks to my mother and father. Also, the supreme confidence they hold in me is no small boost. 
TABLE OF CONTENTS

PAGE

ACKNOWLEDGEMENTS. . . . . . . . . . . . . . . . .

CHAPTER

I INTRODUCTION. . . . . . . . . . . . .

II THE DEVELOPMENT OF DEMOGRAPHIC THOUGHT. . . . . . . 12

Earliest Thought. . . . . . . . . . 14

Mercantilist Period . . . . . . . . 17

England

France

Germany

Summary

Post-Mercantilist Period. . . . . . . . .

England

France

Germany

Two Additional Predecessors of Malthus

Surmary of Chapter. . . . . . . . . 56

II MALTHUS . . . . . . . . . . . . . 59

Biographical and Historical Background. .... 60

What Malthus Said . . . . . . . . 65

The First Essay

The Second Essay

Spengler's Study of Malthus

Malthus and the Development of Demography .... 
viii

CHAPTER

PAGE

IV MARX. . . . . . . . . . . . . 101

Marx's Reasoning Gystem............ 104

Capitalist Accumiation and Population. . . . . 121

The Increassd Deaand for Labour-power that Accompantes kccuralation, the Composition of Capital Remaining the Same."

Relative Dirinution of Variable Capital Simltanecueiy with Progress of Accumulation and Concentration That Accompanies It

"Progreasire Proruction of a Relative Surpluspopui ation or Industrial Reserve Army."

Forme of the Eeietive Surplus-population

Summary . . . . . . . . . . . . . .

V A NEW PERSPECTITE GA HEYM S EOPULATION THOUGHT. . .

Comparison of karr and Walthus. . . . . . .

Philosophical Sisilerities and Differences

Economic Siriiarities and Difierences

Economic and Demographic Questions of Crerpoptiation

Similarities and Differences on Demographic Questions

Anomalies in Mamx..............

Anomalies leted in Comperison of Marx and Malthus

Further tromaities

A New Perspectire On Warr's Population Thought. .

Historical Dereloptrent of Population Thought

Malthus

Marx

Re-Bramining knomaizes In Marx

Remaining Problems wizin Warz. . . . . . .

202

VI

CONCLUSION. . . . . . . . . . . . . . .

208 
REFERENCES. . . . . . . . . . . . . . . . 210 APPENDIX. ............................... 215 
CHAPTER I

\section{INTRODUCTION}

Present estimates place the size of the world's population at four billion. Another billion increase in population size is expected in about 10 years, and by the year 2000 population size is expected to be 6.5-7 billion. Many knowledgeable scholars think population growth cannot continue much longer without dire consequences, i.e. sudden significant increases in death rates conditioned by famine, epidemics, or wars or combinations of these and other factors. Already, in 1975, over 700 million of the world's population (close to 25 percent of the total) are suffering from famine. ${ }^{1}$

Thus, population is an immediate problem and an impending problem so long as growth continues. What are govermments of the world doing about it? Most countries do have population policies; although by no

1 The basic division of the world is set in terms of socio-economic development; i.e. developed (or more developed) and developing (or less developed). This division serves to separate variations in rates of population growth for the world. The developed countries are presently at replacement, or zero population growth, although persistence indefinitely at zero growth is no certainty (also remember zero growth still. means increase in population size for about 25-35 years); the developing countries are growing very fast. The differences between the two regions of the world in terms of socio-economic status and status of population growth rates is not coincidental. It is widely believed that high population growth impedes development in developing regions. See Ronald Freedman and Bernard Berelson, "The Human Population," Scientific American, (September, 1974), 30-31. See also, Joseph Spengler, Population Change, Modernization, and Welfare, (Englewood Cliffs: Prentice-Hall, Inc., 1974), for general background information on population; the same applies to Georg Borgstrom, The Hungry Planet, (New York: Collier Books, 1972). 
means are they all the same. Some countries have policies which amount to having no policy at all. Most developing countries, though, seek to reduce growth rates (though none appear eager to see an end to all growth or to a planned reduction in their population size). Most developed countries maintain pro-natalist policies; some even seek increased population growth rates with vigor; e.g. Romania, and, to a lesser degree, most Eastern European socialist regimes and the Union of Soviet Socialist Republics (USSR).

Thus, the governments of the world have not taken a unified approach to the world's population problem. While policies appear to exist, implying efforts to manipulate population processes one or another way, governments of the world seem more interested in talking about the problem than in making unified efforts to treat it. What the governments are talking about are the causes and solutions to the problem; for in the world there exists two diametrically opposed views concerning the causes and solutions of population increase. The essentially Malthusian Western view regards the principal causes of population increase to be technological tampering with the balance between birth and death rates. The development of death control (1) increased average life-span, (2) increased the probability of each individual born living longer, and (3) reduced infant mortality rates resulting in persistence of high birth rates and low death rates. The Western view considers some sort of "demographic transition" involving the reduction of birth rates to re-balance population as having occurred in most developed countries. ${ }^{2}$ However, the transition has not occurred in the developing countries; the developing countries appear least 
capable of handling rapid population increase beceuse of their technological, industrial, and agricultural "backiarjess," coupled with culture traits and traditions which reinforce large iamilies and rapid increase. Thus, the world population problem appears to be largely a problem for the developing countries. ${ }^{3}$ The iestern rite advocates birth control and family planning programs to control iertility as primary instruments of population control which propide relatirely quick, efficient, and successful modes of reducing population growin rates. 4

2 It remains unclear exactly what factors ard conditions are involved in the creation of a demographic iransition iron high birth and death rates to low birth and death rates; indtsirial derelopment, increased standards of living, culture change, change in romen's rights and roles are all suggested as necessary but the unclear, i.e. should greater stress be placed on indusirial development or culture change? Since the post-world war II daby boom in the developed countries many demographers have been less incitined to embrace the notion that a demographic transition is a necessary consequence of development, or that it is necessarily persistent crer the long-run.

3 Although the principal problen lies wit ine dereloping countries, it is the whole world's problem. Tre demend for increasingly inadequate food supplies drives prices up (moch ine same paitern applies to all resources for even renewable resorices have limits such that indefinite increases in population cannot de supplied). Population pressed nations are driven to economic, socia, snd political instability which makes their participation in rorid economic and political systems troublesome. Their efforts to secure ineis needs leads to world inflation, disruption of markets, and invites anstable political situations which make the possibility of war men seater (and with the proliferation of nuclear energy and weaponry threats of iar become especially grave). Clearly, then, the world, as an integrated system, cannot ignore problems in some sectors which do not directly affect other sectors. An excellent assessment of worid economic problems which derive from population increase (as one factor) is Kenneth E.F. Watt, The Titanic Effect, (Stamford, Conn.: Sinaner Lssociates, Inc., 1974); Chapter 3 on "The Rising Price of Food," is especielly pertinent here.

${ }^{4}$ Davis has convincingly refuted views sugęsitie population control is achieved by merely "family planning." Deris argues other things are needed; socio-economic change, and changes in cultural 
The other view, often called the "socialist view," is (in fact) the modern Marxist view, whose chief advocates and most powerful representatives are the USSR and the People's Republic of China (PRC). 5 The modern Marxist view looks at the world population problem from quite a different angle than the West. Modern Marxists see no problem with world population increase per se. Under a proper system of production, supposedly the world's population could be fed, and the standard of living universally raised indefinitely into the future. The real problem of population facing the world is not purely demographic, but predominantly political-economic. While it is admitted that developing countries actually do have excessive numbers, the problem is not the excessive numbers per se but the inability to economically meet their needs, with the blame for this condition cited as capitalist imperialism and exploitation. The sector of the world with the population problem, developing countries or the Third World, has been severely inhibited from developing because of the consequences of exploitation (in both colonial and neo-colonial forms); those being the taking of Third World resources, the keeping of industrial development and productivity low, the stifling of cultural development, and the perpetuation of government dependence for food supplies, aid, and expertise of capitalists. Thus, the real solution to the problem lies in

attitudes affecting reproduction, e.g. family size desired, religious significance of children, economic utility of children, women's rights and roles must change to successfully control population. See Kingsley Davis, "Population Policy: Will Current Programs Succeed?" Science, 10 November 1967, pp. 730-39.

5 modern Marxist(s)" refers to both the USSR and the PRC. 
revolutionary change. Down with capitalism. Up with socialism. Up with the development of industrial capabilities of individual nations; and with such development, production will increase and exceed the pace of population growth, thus eliminating the apparent problem of population. Finally, the modern Marxist view claims the Western view as being unable to solve population problems. The West proposes family planning and birth control to solve the problem but (1) birth control and family planning do not compel socio-economic change thus perpetuating the exploitation which caused the problem to begin with and (2) by controlling population growth thus, the West keeps the competition from the developing Third World for resources insubstantial compared to what it would be like if vigorous socio-economic development was occurring in the Third World. Accordingly, the modern Marxists claim that the Western position consequently reveals its invalidity to their view. The Western view amounts to nothing more than a theory which rationalizes the continued exploitation of populations of the world, and justifies neglect of problems caused for the populations of exploited countries by arguing that population growth and consequences of overpopulation derive from inexorable natural laws, i.e. that the problem is demographic and not socio-economic. Because of this, and the above focus on perpetuating the status quo, the Western position is considered the invalid Malthusian view. 6

6

Enhanced appreciation of the modern Marxist view is obtained by augmenting the above with the following points. First, the above is a composite of Soviet and Chinese statements concerning the world population problem and more or less reflects their mutual view. A significant point of difference lies in the Soviet emphasis on the need for aid to the Third World from the socialist world while the Chinese 
An examination of textbooks and journals of demography and population studies of the West reveals that the modern Marxist view, as well as Marx's thought itself, has never been considered in any substantial

stress, in contrast, self-reliance, i.e. the development of Third World countries based upon availab?e resources within their own boundaries and without dependence from other nations, especially superpowers. The Soviet view is criticized by the Chinese as being social-imperialist because the USSR seeks world hegemonism using aid as a tool for gaining entry into and influence over Third World nations to further its imperialist goals.

Second, regarding the matter of Malthusianism, it is entirely unclear whether modern Marxists consider all who do not embrace the Marxist perspective as Malthusian or just some. This writer's inquiry into this question could not uncover indications which would clarify this question. It is this writer's estimation that the term "Malthusian" is used in a far more propagandistic manner than one that is scholarly.

Third, several points concerning origins to the modern Marxist view can be made. The population theorizing of modern Marxists is almost entirely derived from Marx's and Engels' thought. The only contribution modern Marxists cite from Lenin is the attempt to rationalize fertility control as a fact of women's rights and not as a NeoMalthusian anti-natalist policy. See V.I. Lenin, "The Working Class and Neo-Malthusianism," Collected Works, (Moscow: Progress Publishers, 1968), XXVI, 127-28. Writers in the USSR do not turn to Lenin, or Stalin, for original thought on population, but to Marx and Engels mostly implicitly; usually, reference to Engels is made when rationalizing the possibility of population problems in the future communist society. This strong implicit rooting of modern thought in Marx appears throughout modern writings in the USSR; a conspicuous example being O.V. Lamin, "On General and Specific Laws of Population," Vestnik moskovskogo universiteta, seriia VII, Ekonomika, 1971, No. 5 , trans. in Problems of Economics, XV, (June 1972), 3-23. In Larmin's article, he argues that the socialist position is superior to the capitalist because the former stresses benefiting the whole of society, the latter stresses exploitation of society. Furthermore, Marx showed that the true forces affecting population were socio-economic, the true method of analysis was dialectical materialism and historical materialism, and population analysis not based on the above was reactionary, and designed to apologize for the exploitation of capitalism. Based on Marx, Iarm argues that there are no general laws of population; population is a dependent variable which is affected by changes in social production. Thus, the task of modern Marxists is to elaborate and articulate the theory Marx initiated by (1) explicating the socialist law of population Marx implied as existing, (2) elaborating in detail the socio-economic relations affecting population, (3) repudiating Malthusian thought through succeeding at (1) and (2), and 
detail. This neglect appears in need of remedy becanse (i) the woridts concern over population problems has brought the debate oper cares solutions to the problem to the attention of the whole vorld, ati on

(4) attempting to insure theoretic continuity and consigtency wit $18=2$ as modern elaborations of Marx are advanced. Thus, it appeas ite $140 \mathrm{i}-$ ern Marxists regard Marx as having advanced a theory of popul is superior to the Malthusian theory with the modern Merxist sesporsibility being articulating it, building up details not present it the initial articulation by Marx. The thrust of Larmin's arganems eas be seen in the following articles as well: D. Valentei, "Carrert Zopzietion Froblems in the USSR," Nauchnye doklady Vysshei shkolyekonomicheskie nauki, 1969, No. 1, trans. in Problems of Econoutes, III, (November 1969), 49-66; R. Galetshaia, "Socioeconomic Probient of Population," Voprosy ekonomiki, 1972, No. 3, trans. In Prodieng of. Economics, XV, (September 1972), 43-50. Note that the abore Sorts writers are all members of the USSR Academy of Sciences.

In contrast, the PRC seems less concermed with articolatide $1 \mathrm{ard}$ and more concerned with applying him to the organization $02000=6$. The Chinese clearly identify their theoretical base for organizinge gociety in their constitution as "Marxism-Ieninism-Mao Tsetung Taoses." See, "The Constitution of the People's Republic of China, "azogsed the PRC January 17, 1975, China Reconstructs, XXIV, (March 1975;, is. Leninism is often considered revolutionary Marxism; the applicatict of Marxism to the scale of world revolution and concern 1 th ineriais which Lenin considered the last stage of capitalism. Thas, bot $0.5 E$ and PRC concerns with population in the Third World can be essa 50 beer the influence of Leninism. Mao's contribution is a strons efpicetion of Lenin's and Stalin's emphasis on practice to the Chinese soctetr; the result being less inclination to publish articulatione of acoilist population theory" as the Soviets struggle to do. Nerertialess, a look at PRC practices reveals strong adherence to Warx; the serie ean be said for official statements of the regime; e.g. see "Chine anjeine Her Views on the Population Questions," Peking Revies, 274021373 , pp. 16-17. Thus, as with the USSR, the population question iz ireates with recognition, both explicit and implicit, of roots in Mez. Accordingly, to appreciate the modern Marxist position, 这 important to understand Marx's thought on population. Furthermere, even to be able to read and understand modern Marxist expreszions of population theory, a solid understanding of marx is reguirsed. Tor example, Larmin argues that key points of the socialiat theor 02 population needing articulation include (1) laws governing popiation reproduction of every formation, (2) the law of full exploysate were socialism, the law of relative overpopulation under capitelian, $\equiv x$ ic $(3)$ demographic patterns associated with the biological structars of popraletion. Now, the first point stems directly from Marx's iainare to discuss population in other historical periods (past or intare) wit different modes of production other than capitalism; the seconi 
one of the premiere forums for world debate, the United Nations, the opposing views have recently been advanced vigorously and extensively, and given serious attention by the Third World in particular, (2) the modern Marxist position is attractive to suffering Third World countries, especially those that were former colonies of capitalist powers, and thus, (3) the West can no longer neglect the postion. Accordingly, the modern Marxist position needs to be studied critically. The question which shall primarily concern this study will be whether the modern Marxists have correctly located the theoretical roots of their views in Marx, i.e. was Marx writing a theory of population? To probe this question, inquiry into Marx, and Marx's place in the historical development of demographic thought, is necessary.

To treat the questions of this primary focus, this study is organized into six chapters. After this introduction, Chapter II will provide background on the history of demography. This will be important in Chapter V. Chapter III will state the theory of population of Malthus, the principal antagonist toward whom Marx directed criticism as he advanced his thought on population. Chapter IV will carefully

question stems directly from Marx implying a socialist law of population in his articulation of the law of relative overpopulation under capitalism (which was advanced with some troublesome anomalies in it, implied as needing resolution in Larmin's statement); the third point deals with hard demographic principles like age, sex, birth and death rates which Marx did not concern himself with explicitly in his discussion of population. The fact that it is considered insignificant relative to (1) and (2) reveals again Marx's influence.

This writer has taken pains to stress the importance of considering Marx because Western neglect of modern Marxist thought might elicit questions of the importance of this study. It should be more clear that to appreciate claims that there is a socialist law of population, originating in Marx and superior to Western views on population, Marx himself must be examined carefully. 
articulate Marx's thought on population. Chapter V will bring together the preceding three chapters to look critically at Marx. Marx will be compared with Malthus. Some anomalies in Marx's thought emerging from comparison and analysis of Marx will lead to the conclusion that a new perspective on Marx is needed. The reconsideration of Marx will take shape through placing Marx into the historical context of the development of demography. This will lead to conclusions which suggest that anomalies can be resolved by the new perspective. Nevertheless, critical problems with Marx will remain which suggest that. in addition to Marx not writing a theory of population, he cannot be regarded as a fruitful root in which to anchor modern Marxist thought if the claim to significant difference from Western thought is to be maintained. Chapter VI will summarize the argument via concluding that modern Marxists may be claiming a position that, based on its origins, is not justified, correct, or viable.

Some critiçs may suggest that this study is built upon insubstantial foundations whose relevance to modern concerns of population are questionable. This writer, of course, rejects this view for several reasons. First, the Western view regards Marx as not having written much on population. This is witnessed by the lack of concern for Marx in textbooks and journals. A careful look reveals more to Marx's thought on population than has been previously thought. Furthermore, there is practically no careful examination of Marx's thought in print, so there is contemporary relevance and importance to this study if for no other reason than that it looks deeper and more critically into Marx on population than has been done before. ${ }^{7}$ An effort such as this 
is especially timely considering the zrs-exinence of the population debate on the world forun.

Second, this study makes a controtion to increased appreciation of modern Marxists. Without a thorowzi appzeciation of Merx and Engels (and to a much lesser degree Ienin, Jiein, and Wo) the language and reasoning structure of modern Wardet emicnlatione can be more confusing and difficult to understene then tes otberwise would be. 8 Furthermore, an essential element of arijeiden of modern Harxists is found in analysis of Marx's thougt, is place in the development of demography, and in a new perapectipe wich resulte from a critical examination of Marx. Finaliy, thete is reierance to this study because it reveals a dimension to Marx wibis des not been observed before. Third, this study makes a contrication to the development of

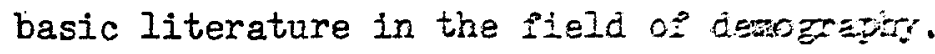

The question may arise on the zesiz op this last point, if the literature needs developing, how ta to posiole to make a "thorough study?" The question reveale ons proviem izth espects of this study. Chapter II and IV found difpionities in tie pancity of bodies of literature from which to build. Thes yelncipel works were used in

7 There appear to be oniy two reietent eseays of any detail on Marx. Samuel M. Ievin in Malthaz and ias Conguet of Iife, (New York: Astra Books, 1967), pp. 90-105 discases vers in part of a chapter in his study of Melthus. It is rot tos rerseizine becange Levin was not directly concerned with Marz. Wiliten Fetereen in his Marx versus Malthus: The Men and the Symbola, in Zenueti C.i'. Kamneyer (ed.), Population Studies: Selected Esaera end Eesearch, (Chicago: Rand McNally and Company, 1969), pp. 76-90 : 150 not thorough enough. Usually, studies of Malthas inclade critusane of Halthus in which Marx is noted in a superficial, and dezílitely incomplete way.

${ }^{8}$ See footnote $6,0.6$, for en exemigie. 
Chapter II because these were the only major studies in the field. ${ }^{9}$ Chapter IV found this writer compelled to do basic research into Marx's writings, reading from most of Marx's and Engels' works because no studies of Marx's population thought were considered satisfactory in terms of extensiveness, detail, quality, or sophistication. Furthermore, there was only one edited work on Marx's population thought in print; while thorough, this work was remiss in providing adequate background on Marx's general reasoning, purpose, and larger economic focus in which thought on population occurs. 10

In contrast, studies of Malthus were profuse. Chapter III, therefore, posed no research problem; only one of attempting to communicate Malthus' population thought with adequate detail, concisely, and without the taint of contemporary interpretations which add more confusion than clarity to Malthus.

${ }^{9}$ Charles Emil Stangeland, Pre-Malthusian Doctrines of Population, (New York: The Columbia University Press, 1904); Joseph J. Spengler, French Predecessors of Malthus, (New York: Octagon Books, 1965); James Bonar, Theories of Population from Raleigh to Arthur Young, (New York: Augustus M. Kelly, Bookseller, 1966). Note: While more substantive studies like these would have helped, the reputations for scholarship of these writers make this literature acceptable for this study.

${ }^{10}$ Ronald I. Meek, ed., Marx and Engels on the Population Bomb, (Berkeley: The Ramparts Press, 1971). 
CHAPTER II

THE DEVELOPMENT OF DEMOGRAPHIC THOUGHT

Whether the subject is modern expressions of Marx's and En: 'Is' thought, or Marx and Engels themselves, Malthus is, one or another way, considered. However, rarely is any mention of population thought prior to Malthus, which bears on Marx and Engels, or Marx versus Malthus, considered. Such Iimitations seem inappropriate. A broad look at the development of demographic thought with an eye on putting Marx in the context of the wider flow of history reveals heretofore unnoticed insights. In this chapter, the central purpose will be to develop the history of demographic thought to provide the basis for putting Marx in the wider flow of demographic history. The chapter begins with thought of ancient, early Christian, and late medieval times followed by consideration of the mercantilist position. Following this, post-mercantilist $^{1}$ thought is presented. Mercantilist, neo-mercantilist, ${ }^{2}$

${ }^{1}$ A term was needed as a rubric for the period following the decline from doininance of mercantilist views on population. It was not the case that Malthusianism rose to dominance immediately after the decline of mercantilism. A period where many schools of thought flourished existed before Malthusianism became comparatively dominant (although no thought has dominated with the power that mercantilism once did). This period shall be called "post-mercantilist" for purposes of this study. It bears emphasizing that post-mercantilist thought on population covers most of the 18th century, but should not be construed as implying the termination of the influence of mercantilist thought. Mercantilist thought persisted in the post-mercantilist period, but, in contrast to prior time, was no longer dominant.

For purposes of this study, neo-mercantilism shall mean 
pre-Malthusian, ${ }^{3}$ and pre-Marxist ${ }^{4}$ schools of thought fit under the rubric "post-mercantilist." Primary concern will be with 17 th and 18 th century Western European developments. A table picturing principal

essentially mercantilist views concerning the merits of populousness, but variations in thought concerning aspects of the classical mercantilist argument, e.g. some rejected the mercantilist assumption that states were natural enemies, that the reason for population increase had to be military, or some rejected the mercantilist emphasis on manufacturing for trade considering agriculture and self-sufficiency as the keys to stimulating population increase.

3In the course of this writer's research it became clear that no historical examination consulted by this writer ever specifically stated a criterion for categorizing a writer as pre-Malthusian. Indeed it became apparent that ambiguity on whether a writer should be so classified existed. For example, Aristotle is generally considered pre-Malthusian because he recognized that population was checked by food supply, and other natural conditions like disease, epidemics, and disasters. However, Aristotle is considered a weak pre-Malthusian because other than recognition of a food check on population, his views were vaguely stated, with one exception. Aristotle thought homosexual behavior should be permitted as a check to population. This is clearly a positive check in the Malthusian sense but Aristotle is not cited by scholars as a pre-Malthusien for making this point. Aristotle is one of many examples which could be cited. He is sufficient to make the poirt. This writer felt compelled to note difficulties in the existing literature categorizing writers as pre-Malthusians. The critical reader may ask, as this writer has, at what point do observations made by a writer become sufficient to be classified as pre-Malthusian? This matter is not easily resolved and needs considering to make historical studies more precise (something beyond the purview of this study). Since there appears a strong tacit agreement in historical literature concerning categorizing a writer as pre-Malthusian, for this study, the precedents of the literature will be followed.

4 The same sort of question noted in footnote 3 can be asked of the category "pre-Marxist." However, unlike the pre-Malthusian category, strong precedents in literature cannot be employed as a basis for making judgements as to whether a writer is a pre-Marxist. In the case of French writers, this writer will follow Spengler's categorizations. For this study as a whole, writers shall be considered pre-Marxists if their thought anticipates one or more major components of Marx's theoretical system which bears on the question of population as Marx developed it. Largely, this confines the category to some population-wage relationships discussed, the partial anticipation of the notion of surplus-value and its dynamics, and a few 
writers and subject areas or factors related to population they noted in the development of demographic thought prior to Malthus can be found in the Appendix. It is intended to aid the reader in visualizing the developments discussed in the following sections.

\section{EARLIEST THOUGHT}

Concern with population has persisted from the earliest cultures of man. The earliest religious teaching, Zorastrianism, Hebrew teachings, and early Greek mythologies, include concerns for population in the form of pro-natalist canons which served to protect population size from decline and stimulate growth in population size. 5

Beyond early religious teachings, concern with population appears in both Greece and Rome. In Greece, two thrusts appear; one involves policies and practices in city-states to encourage population increase. Sparta is representative of such efforts. The other thrust involves philosophic thought of Plato and Aristotle. The Greek city-state of Sparta, perhaps more than others, had a strong view of the positive value of population reproduction and growth. Considering Sparta's warring nature, strong pro-natalism persisted; laws encouraging marriage, punishing celibacy, and legally and politically penalizing bachelors prevailed.

writers who are not specifically anticipators of Marx on population but whom Marx read, studied, and clearly was influenced by in his work which does affect his population thought. For the most part, anticipations of Marx are found in 18 th century French literature and some English writing of the same time period. 
Plato and Aristotle struggled with the idea of optimum population. Both identified factors which encouraged and discouraged population increase; factors which vaguely anticipated Malthus. Both attempted to suggest policies which would balance positive and negative factors to realize their goal of optimum population size. Apart from typical means of encouraging and discouraging births (i.e. manipulations to encourage marriage, status changes penalizing bachelors and celibates, changes in marriage age to either encourage or discourage growth) Plato thought the most prolific reproducers in society should be restrained to control growth, and Aristotle added the idea of permitting homosexuality.

Both city-states and Plato and Aristotle recognized the possibility of overpopulation. All thought it a remote possibility, citing colonization and emigration as the solutions to the problem. 6

There were no major changes from Greek thought or practices by Rome. Rome merely extended and intensified modes to encourage population increase employed by the Greeks.

The early Christian period which followed the decline of Rome saw a period when concern for population suffered an ambivalent stagnation; on the one hand elements of the religious teachings were pro-natalist, e.g. the masses were encouraged to marry, and divorce, infanticide, and abortion were condemned; on the other hand anti-natalism infested the teachings also, e.g. stress on asceticism and self-denial were

6"The Determinants and Consequences of Population Trends, A Summary of the Findings of Studies on the Relationship between Population Changes and Economic and Social Relations," Population Studies, No. 17, (New York: United Nations, 1953), pp. 18- $\overline{26}$. 
strong influences in the early Christian theology.?

In contrast to the ambivalence of the early Christian period, the medieval period just prior to the Renaissance found a strong re-emphasis on pro-natalism. The re-emphasis had great momentum by the time of Martin Luther (1483-1546). ${ }^{8}$ Celibacy was condemned, controls on marriage were loosened, sexual behavior was freed relative to earlier periods, and remarriage appeared. 9

The period of the Reformation was a period of general social system change in the development of Western civilization; namely, from the feudal manor based system of production to handicraft and to the initiation of factory type manufacturing. This was also the period of the germination of capitalism, the urban commercial revolution, and the beginnings of modern nationalism. So in fact re-emphasis on population and changes in controls on reproductive behavior can be viewed as elements in a general social system change.

This transition period saw the rediscovery of Greek thought and practices and this plays heavily in mercantilist attempts to stimulate the greatest increases in population possible.

${ }^{7}$ Stangeland, pp. 61-87.

${ }^{8}$ The usual historical marker symbolizing the initiation of the Reformation is Martin Luther's posting of his Ninety Five Theses in 1517.

9 Population Studies, No. 17, p. 23 n. 


\section{MERCANTILIST PERIOD}

Mercantilism a political and economic system which grew up with the building of nations. State governments, from the middle of the 16 th century to the middle of the 18 th century, were becoming increasingly powerfuI and expensive. Such governments required both people and money for maintenance of large and often permanent armies, and for support of a conspicuously consuming Iuxurious ruling class. Each nation worked for its own welfare, often at cross-purposes with the individual epforts of other nations doing the same thing. Accordingly, military strength a necessity and economic pre-eminence became essential for jolitical supremacy. Further characteristics of this period involved centralization of manufacturing and commerce in urban areas conditioning the basis for denser populations, shifting of local and personal economies to national economic policy and regulations. Indeed, the mercantilist period was primarily a period which focused on growth of political, economic, and national strength. Not surprisingly, there existed a preoccupation with increasing population size during mercantilist domination of society.

Population was regarded as important to mercantilists because of economic beliefs in how to increase national strength. The major source of increasing national strength was thought to be the amount of precious metals in possession of a nation; this determined economic power. Thns, the ain of the state was acquisition of gold and silver, and a farorable balance of trade, 1.e. greater exportation than importation, was regarded as a major means of achieving that goal. 
Accordingly, emphasis was placed on production of exportable commodities. This required skilled manufacturing trades and large numbers of workers to produce great quantities of goods. Indeed, it was felt the greater the population the more production could occur, and the more the production, the greater the exportation of goods. Consideration of population, therefore, was integrated into larger economic, political and nationalistic concerns for national wealth and strength. Accordingly, no population theory per se developed during the mercantilist period; instead, a tacit theory evolved as increasing attention was given to population as an element crucial to increasing national wealth and strength.

Economic well-being was felt to rest on production, and balance of trade. But it was also believed that government regulation of production and trade was important to insuring realization of economic goals. Since population was regarded as an important factor in economic progress, much of the concern over population in the mercantilist period involved both government regulations of population processes (e.g. marriage age, and most other controls the Greeks devised) and proposals for new regulations of population. All attention was devoted to regulations which would increase population. There was no fear of overpopulation or negative consequences of any type occurring from population growth; ceteris paribus its consequences were considered positive. Thüs, penalties were imposed on celibates and bacheiors, marriage was encouraged, especially early marriage, special privileges were provided for marriages and early marriages, including tax breaks, which increased as family size increased, and fertility was encouraged 
via reducing or eliminating punishments for illegitimate births, and rewards and immunities from taxes to fathers with numerous offspring, pro-immigration laws, and laws against emigration were developed. 10 During the mercantilist period virtually all Euorpean nations operated with similar economic and political aims. Hence, the same types of regulations to stimulate population growth can be seen in virtually all European countries of the time (though some variations in stress occurred because of different development conditions in different nations, e.g. England's long belief that the country was overpopulated found the effort to stimalate growth subdued for some time while France early on struggled to increase its population size). While govermments struggled to implement policies to increase population size, and many advanced proposals to be made into new policy, England, France, and Germany produced individual scholars or clusters of scholars that may be identified as marking significant innovations in population studies. These individuals or groups merit presentation for they play an important role in Chapter V.

England

While at base there was general acceptance of the positive merits of pro-natalism, foundations for consideration of population find three foci on population in England: (1) mathematical considerations of

${ }^{10}$ Stangeland, Ch. IV. It bears reiterating: note the similarity of regulations to those used by Greeks and Romens. Also, to advance such regulations, some thought into population questions, e.g. what makes population grow, had to occur. Judging from the type of writing of the period (with the exception of a few individual writers or clusters of writers, like Graunt or Petty) it seems clear that at best a tacit theory of population was followed. 
population problems, with Captain John Graunt (1620-1674), Sir William Petty (1623-1687), and Sir Matthew Hale (1609-1676), (2) concerns with comerce and population, i.e. the more purely mercantilistic writers, and (3) some uncategorizable individuals with divergent interests. Neither the second or the third category offer significant writers who add dimension to previously summarized perspectives of mercantilist population thought. The first category does offer some important innovation, and thus merits further notation.

Up to about 1650 most English writers believed their country to be overpopulated and in need of colonies to draw-off excess numbers. ${ }^{11}$ To a large degree, then, the English inquiry into population asked the guestion, is population excessive and is it persistently so? The effort to find out brought the development of statistical tools, the gathering of census data, and hence the development of a quantitative approach to demographic inquiry. Graunt, Petty, and Hale were responsible for this development. Indeed, Graunt is often regarded as the father of demography.

Graunt's work occurred at a time when plague persisted in Ingland. Graunt studied mortality rates and compared them to estimated birth rates. He concluded that the population was not rumerically wiped out by plague; that replacement of the dead occurred in about two years. Graunt's efforts led to the first detailing of types of deaths. Overall Graunt's efforts were originai because his were the first attempts to speak of population in terms of numbers.

${ }^{11} \mathrm{Sir}$ Walter Raleigh $(1552 ?-1618)$ is an exception. He is a true pre-kalthusian. He will be considered in the post-mercantilist section. 
Graunt struggled to identify processes which affected changes in (1) popolation size, e.g. diseaze and regeneration, (2) composition of population, e.g. relation o: cinconic disease to rate of mortality, common accident to rate of mortality, excess of male over female births, high death rates in eariest periods of life, and (3) distribution of population, e.z. excess of death rates in the city over those in the country, and that country-io-city migration was a major source of replenishment of city popuiations. Graunt's work, therefore, encompassed studies of size, compsition, and distribution of population in terms of mortality, fertility, and migration trends. ${ }^{12}$ His observations were based on quantitative information (though inaccurate and incomplete) and he tried to explain observed processes in terms of natural law. Graunt reached the conclusion that monogamy was the natural law for reproduction becanse it was the best way to facilitate greatest possible growth. ${ }^{13}$ Zinally, Graunt regarded population growth as tending to be geometrical; gecaetricel growth was natural, as were checks on such potential in the Porm of plagues and wars. For moking these last observations, Grant may be considered anticipatory of Malthus. 14

Petty's work on popalation applied the statistical tools advanced by Graunt in a broader economic perspective. By tying

${ }^{12}$ Bonar, Op.Cit., po. 67-82.

13 Stangeland, pp. $149-43$.

14 While correct to consicer Grant pre-Malthusian for these observations, it must be stresed that Graunt was a strong mercantilist as well. He believe in the imortance of and merits to populousness. 
population to economics, Petty concluded that population growth would be no problem. This conclusion was reached in the following way. Petty saw "economics of concentration" as keys to making small nations with small populations equivalent or superior in power and wealth to larger nations; through concentrations greater growth could occur. What Petty meant by concentrations was improvement in methods of trading, in trade policies, and in increased intensiveness of agricultural production which would result in increased value of the product. By accomplishing the above, population increase would be encouraged; the result of which would be increased national strength. Petty favored a large population because he thought it a clear indicator of prosperity. However, pure growth of population was not regarded as necessarily beneficial. By tying growth of population to economic development, Petty thought he could make growth always beneficial. Through quantitative analysis, Petty made conclusions about changes in population size which led him to believe that population growth was geometrical in character. Petty recognized checks to population, as Graunt noted, and felt no fear of overpopulation because, having tied population to economic growth and development, he felt growth of population would always be in a beneficial form. 15

Hale carried forward Graunt's work; he accepted the conclusions of Petty as well. More than Graunt or Petty, Hale emphasized the

${ }^{15}$ Bonar, pp. 83-100; Stangeland, pp. 143-46. Note, since Petty was a close follower and associate of Graunt, it is appropriate to see Petty as anticipatory of Malthus as well. Petty's lack of fear of overpopulation because of his connection of population to economic growth and development is essentially anticipatory of Marx's position on the question of orerpopulation. 
potential for rapid growth of population in a short time; estimating the doubling time for population to be every 35 years, he saw it checked by natural conditions, Iike famine, earthquakes, floods, wars. ${ }^{16}$

\section{France}

While original work by Graunt, Petty, and Hale was occurring in England, France found vigorous mercantilism the rule. The mercantilist position reached its highest development with the reign of the Finance Minister of France under Louis XIV, Jean Baptiste Colbert (1619-1683). Colbert sought to accelerate population growth by all means the Greeks and Romans employed plus some innovations of his own. Because he thought population increase occurred with increased employment, or demand for labor, he tried to stimulate business activity by surpressing idleness, by reducing the number of holy days, encouraging employment of children, and by making laws against vagabondage and mendicancy. For all his efforts, Colbert's programs proved ineffective. By the close of Colbert's reign, mercantilism in France had lost its position of dominance and many different views, or schools, on population and economic matters flourished. The impetus to such proliferation of schools can be found in the utter failure of Colbert's programs which left France in a state of political and economic shambles. 17

${ }^{16}$ Stangeland, pp. 148-49.

${ }^{17}$ Spengler, Op.Cit., pp. 13-27. 
Germany

Germany, like France, was dominated by mercantilism during the period Graunt and his associates in England worked. In Germany, some notable indiriduals made important contributions to subjects which afiected popalation thought particularly in post-mercantilist writers. These indiriduals include Pufendorf (1623-1694) for his idea of "natural Iaw," and Conring (1606-1681) and Leibnitz (1646-1716) for ineir contributions to statistical theory.

Sarmel Freiherr von Pufendorf is credited with significantly oringing into prominence the concept of "natural law." While it cannot oe said that Fufendorf "coined the term," his extensive use of it in discussion of population growth is original. Pufendorf's treatment of population is considered by stangeland to be quite objective relative to cther mercantilist writings, although based upon a moralistic, or theological, position. While regarding populousness as generally beneficiai, he did not regard coercive stimulation of population Erowth as valuable or acceptable. Marriage should not be stimulated by positive penalties on the unmarried, or non-reproductive. He rejected vice and promiscuity but similarly rejected curbs on freedom of movezent, 亡.e. restrictions on imnigration and emigration. Thus, for Fupendort, freedom was considered a key to a "good" society, and apparently such societies "naturally" provided the best conditions for positive population growth. 18

Eermann Conring was the last of the significant German scholars ${ }^{18}$ Stangeland, pp. 185-88. 
who studied population processes. Conring was an ardent mercantilist and his notions concerning population are typical of the mercantilist thrust. The element which makes him important is his founding efforts in advancement of modern statistics. He must be ranked as one of the fathers of statistical theory along with Graunt and Petty. Conring used quantitative tools in mach the manner of Graunt. Conring's contribution in this vein served to renforce the emerging practice of increasingly systematic study of population. 19

Gottfried Wilhelm von Leibnitz is not important because of his population views, for they were typical mercantilist views, but because his work in mathematics advanced the course of statistics as applied to population studies which comes to a place of importance with the work of the great German, Sussmilch, who will be considered later in this chapter. 20

Summary

The mercantilist period saw a concem for maximizing increases of population. Doctrines, theorizing, and policies generally focused on identifying relationships between population and other factors, e.g. food supply, employment, trade, industrial production, moral climate, marriage, migration, and mortality, to help in contriving policies which would further stimulate population increase. Deviating from

${ }^{19}$ Conring is a link to Sussmilch via Leibnitz and provides the quantitative tradition of population study Sussmilch used in developing his theory; this is the same tradition which is carried forward to later influence Malthus.

20 A broad discussion of German writers of this period can be found in Stangelend, pp. 185-211. 
this main drift were a few scholars who focused more objectively on the study of factors which affected population growth and decline. Even with more objective efforts the focus of some writers, there did not appear to be any deviation in the general belief in the merits of populousness. Because a few thinkers in England and Germany were less politically and economically dogmatic than most mercantilists, a quantitative groundwork and tradition of systematic study of population was established. In France, the failures of Colbert proved fruitful ground for the development of many competing schools of thought on population which followed the demise of Colbert's reign.

\section{POST-MERCANTIIIST PERIOD}

In England, mercantilism declined through the first part of the 18 th century as new views emerged so that by mid-century, mercantilism was clearly no longer dominant. In its place, a proliferation of schools developed including (1) mercantilists and neo-mercantilists, (2) pre-Malthusians, (3) pre-Marxists, and (4) a noncategorizable group debating the populousness of antiquity. In contrast to England, French mercantilism declined from dominance quite early in the 17 th century, leaving nearly two centuries before Malthus in which complex, interconnected, competing schools of thought on population emerged. Because of the complexity of France, it will be useful to briefly note the many schools, categorized by Spengler as (1) neo-mercantilists and agrarians, (2) repopulationists, (3) Cantilion and the theory of Iuxury, (4) Quesnay and the physiocrats, (5) the Philosophes, (6) the nonphysiocratic economists, and (7) the extreme antiphysicarats. 
After noting these schools, pre-Malthusian and pre-Marxist strains running through the network will be noted. Relative to England and France, not much happened in Germany with the exception of Sussmilch's development of a population theory.

England

Four categories of thought appear in the post-mercantilist period. Mercantilists and neo-mercantilists need no consideration as the views of these writers are close reflections of preceding writers. One individual writer of this group merits a note, however, for he is anticipatory of the view expressed by MaIthus concerning poverty. The Reverend Thomas Alcock (1709-1798), while considering populousness to have positive value, saw increase of population as possibly leading to increased poverty. Alcock rejected the merits of the English poor laws, which were designed by Queen Elizabeth to render assistance to the poor who could not support themselves, as tending to injure industry and frugality. Fear of the consequences of coming to want was viewed as a prime motivation to productivity and the burden of supporting the increasing numbers seeking restitution worked to discourage population increase. Poverty had always existed in human society and always would exist, caused by "sloth, extravagance, sickness, misfortunes of fire, of storm or innundation, lameness, blindness, the weakness of infancy and old age." For Alcock, the solution was to reduce idleness, drinking, gambling, and vice which in turn would act to stimulate growth, both economic and population. 21 
A subgroup of scholars debating the size of population in antiquity, often called the Hume-Wallace Controversy, and pre-Malthusians merit consideration. A fourth group can be abstracted from the other groups; being the pre-Marxists, an, of course, they too need noting. The Hume-Wallace Controversy. The great philosopher David Hume (1711-1776) provides demography students with one of the most thorough and systematic examinations on the problem of population from the historical perspective, according to Stangeland. 22 Hume sought to disprove the accepted belief that ancient nations were highly populous. In the course of his analysis, Hume noted the potential for geometrical growth of population and suggested checks on growth were operating to prevent the potential from becoming actuality; the checks included slavery, vice, disorder in society, and large cities.

Doctor Robert Wallace (1694-1771) challenged Hume's conclusions. Wallace saw limits of food supply checking population increase. Wallace thought modern nations were less populous than ancient nations because modem commercial life and society had detrimental effects on reproduction; including war, poverty, civil and religious corruption, debauchery, idleness and luxury, and whatever weakened marriage. Such checks operated in addition to physical checks such as temperature, climate, soil quality, plagues, earthquakes, and limits of food supply. The potential of a doubling of population every 33 years was prevented from occurring because of such limits caused by checks.

The Hume-Hallace Controversy is important because it is a

$$
{ }^{22} \text { Ibid., p. } 275 .
$$


question which Malthus considers and integrates into his theory of population on the one hand, and on the other hand, finds both Hume and Wallace noting checks which Malthus also noted. Thus, their concerns may be said to have led them to pre-Malthusian conclusions. ${ }^{23}$

Pre-Malthusians. English pre-Malthusians may be separated into three time periods; early, mid-18th century, and late 18th century. The early predecessors include Raleigh, Bacon, and Hobbes with Raleigh the most significant. Raleigh thought population would rapidly orerburden the earth with numbers, being checked from continued growth by hunger, pestilence, crime, and war, and abstinence and artificial sterility. Raleigh thought control of population was essential and should occur before population exceeded food supply.

Mid-18th century predecessors included Franklin, Fergoson, and Steuart. Benjamin Franklin (1706-1790) studied factors stimulating and discouraging population increase. He is one of the few witers to whom Malthus acknowledges a debt of influence. Franklin regarded population increase to be proportional to the number and fertility of marriages compared to number of deaths. Discouraging economic conditions served to dampen sbility to support families, and early marriages. Other checks to population included food supply limits, heavy taxation, and crowding. ${ }^{24}$ In comparison to Franklin, Doctor Adam Ferguson (1723-1818) was a modest predecessor to Malthus. Beyond noting the usual checks to population, Ferguson observed that population tended to persistently increase up to the linits of the means of

$$
{ }^{23} \text { Ibid., pp. 277-80. } \quad{ }^{24} \text { Tbid., pp. 269-73. }
$$


subsistence. ${ }^{25}$ Sir James Steuart (1712-1780) focused on the natural and rational causes of population increase. He thought the difference between man and other animals was man's ability to cultivate the land; without this advantage, man would be limited in numbers just as other animals. Steuart thought the amount of cultivatable subsistence to be quite variable, and hence, the ultimate size of the population was uncertain. He did regard population to be limited to the availability of food supply; in this regard, Steuart connected population growth proportionally to increase in food supply. Also, Steuart saw population increase related to price of labor, suggesting that the need for labor affected its price, and scarcity of it increased labor's price which in turn stimulated population growth whose consequence was increased labor supply and decrease in price of labor. Thus, Steuart argued population size should be balanced to available food supply and to full employment. 26

Late 18th century predecessors (virtual contemporaries of Malthus really) included Adam Smith; Young, Tounsend, Paley, Price, and Chalmers. Because of importance in Chapter V, Adam Smith will be considered more extensively than the others of this group. While Adam Smith (1723-1790) did not advance any extensive discussion of population anywhere in his works, he must be considered an important predecessor of Malthus because of what he did discuss. Smith saw relations between population growth and poverty. He thought fertility to be inversely related to poverty; i.e. women who were the poorest

$$
{ }^{25} \text { Ibid., pp. 284-87. } \quad{ }^{26} \text { Ibid., pp. 287-90. }
$$


appeared the most fertile. However, reproductivity was one thing, and ability to raise children successfully was quite another. Smith found it common to see poor women bearing twenty children to have two survive. Smith thought high infant mortality among the poor counterbalanced high fertility. Furthermore, in every species of animal, it was natural to see increases in population up to limits of food supply but never beyond available subsistence. In human society, social stratification was the limiting factor of subsistence working only among the "inferior ranks of people;" whose principal agent of regulation of population increase was high infant mortality.

Adam Smith observed a direct relationship between increase of wages and increases of population; because it encouraged more marriages, enabled parents to support and raise offspring, thus, as a result, .. reducing infant mortality rates. So long as wages increased, population increased; but reaching stationary or decreasing rates of wages conditioned stabilization or reduction of population size. Furthermore, Smith connected wage-population relations to fluctuations in production and consumption. An "increase of stock" gave cause for raising wages (to stimulate consumption) while it lowered profits. Since raising wages benefited the masses, and wage-population rate increases were a direct relationship, increased population resulted. On occasion of increased consumption, wealth increased which also stimulated populaincrease, but these increases in population worked to reduce wage levels (presumably because increased numbers compete for relatively the same number of jobs), which in turn discouraged population increase. Adam Smith's observations are pre-Malthusian because (1) there 


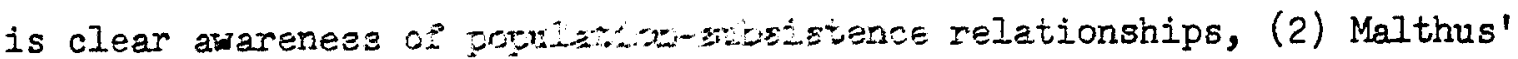
discussion of "internettate wrs" bear strong resemblance to Smith, and (3) Smith's discrazkor $\therefore$ vas-population relationships appears to take for granted Jartove pos: $x=$ wro preventive checks of Malthus, including the idea of preckes as: rational means of regulating population growtin. 2 ?

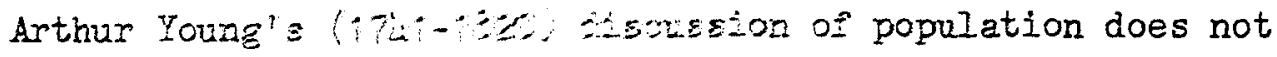

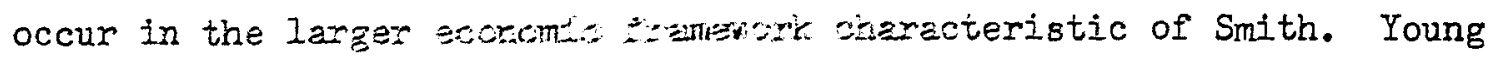

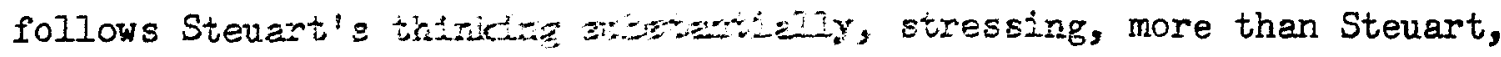
the idea that population torer to soresee faster than society's ability to meet demande $=2$, sor ari employment. 28

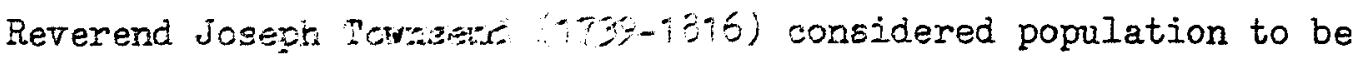

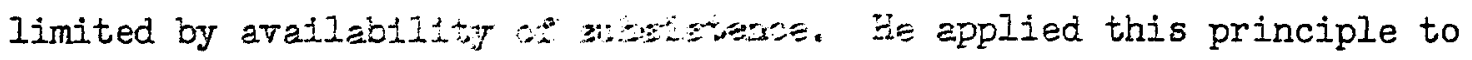
an examination of the poce lary wainding that procreative powers

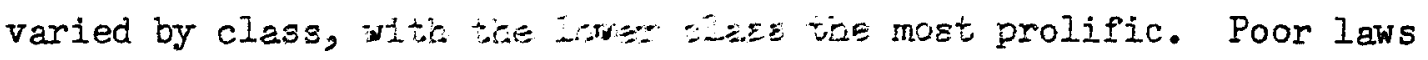

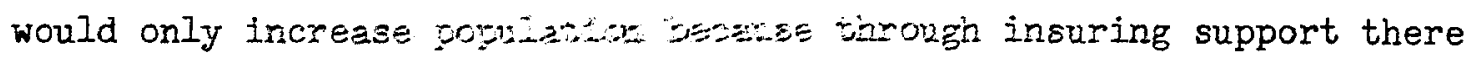
was no discourazemert to

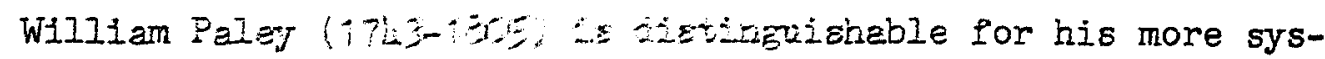
tematic treatment of the $30.0 \%$ poplation but fits into the

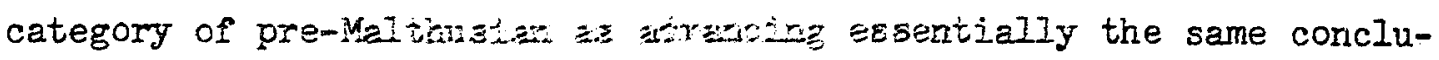
sions as others. The potentiv syorese in numbers was viewed as

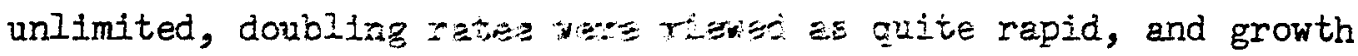
checked by famine or ceatiane wes picily replaced. The ultimate

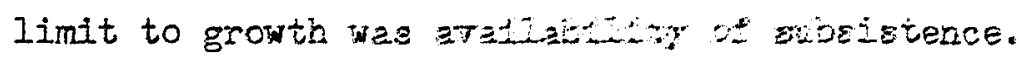

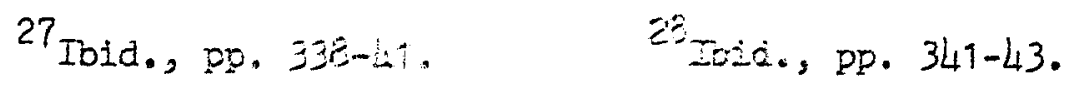


Doctor Richard Price (1723-1799) may be distinguished for his efforts to carry forward the mathematical tradition established by Graunt. Price thought population would naturally increase until physical or moral checks halted it. Price's views followed the pattern of others in this category except for his insistence on the importance of resting conclusions on quantitative grounds. 29

Pre-Marxists. In England, it appears that no clear-cut school of pre-Marxists can be identified, as in France. Instead, what appears are individual writers, mostly predecessors of Malthus, who offer ideas regarding population and economic processes which appear to some degree appropriated and synthesized by Marx. In this context, this writer considers Wallace, Steuart, Adam Smith, and Young overlapping kelthus and Marx. Wallace may be considered a modest predecessor of Harx because in Wallace is found an early advancement of the view that technological changes in society affect the ability of a nation to meet needs of increasing population. Steuart's anticipation of Mark lies in his connection of fluctuations in population growth to the price of labor. Adam Smith carries forward this perspective, becoming the most significant precursor of Marx (1) through his extensive elaboration of the impact on population growth of economic changes such as productivity of labor, and (2) especially by connecting the laborer's subsistence to wages. Smith's view of inverse relations of fertility and wealth is also important in Marx's formulation of population thought. Ioung's anticipation of Marx Iies, as in the case of Steuart and Smith, in his ${ }^{29}$ Ibid., pp. 343-47. 
recognition of the impact of the price of labor on population growth.

\section{France}

As noted earlier, several schools of thought prevailed in postmercantilist France. It will be useful to provide overviews of these schools and conclude by noting Malthusian and Marxist strains which mun through the network of schools.

Neo-mercantilists and agrarians. Neo-mercantilists and agrarians accept the mercantilist belief in the merit of populousness; they differ over the question of the proper focus of economic organization. Neomercantilists in France rejected the mercantilist emphasis on nations being natural enemies and statecraft being focused on war preparation but did maintain that industrial processes were essential foundations for a growing, strong, and wealthy nation. The agrarians in contrast, while agreeing about the inappropriateness of focus on war, felt the strength of society rested in agriculture, and not industrial development. John Law (1671-1729) represented the former, J.F. Melon (16751738) represented the latter. Law tied population processes to fluctuations in production and circulation of money. Melow saw population tied to food supply such that population could only increase so far as food supply increased. Melon thought there was always an upper limit to numbers supportable by a nation. Misery, poverty, malnutrition, lack of food, pestilence, war, conquest, earthquakes, and faulty distribution systems acted as checks to population growth. Melon apparently saw a relation between standard of living and population such that increases in the former checked growth of population. 30 
naseratizatic with the variation from classic mercantilism being belief thez prance was depopulated, continuing to depopulate, and hence in need Q2 zepopiation. Two variations on perspectives appear within this actosi; ne eaw apparent demographic decadence of France as a concern MrE $2 y$ becane of its implications for national strength, the other rentertan a humitarian concern regarding depopulation as a symptom of netcare sickness of both the social structure and the spirit of the pepie of zance. For both views the general remedy was thought to be $z=20$ suction of the society; principally the government. 31

amililon and the Theory of Luxury. Richard Cantillon (1685173 dekes important contributions to inquiries on population as he derelope hite theory of Iuxury. Many schools following Cantillon take Fron 21 work either for support or as a view to criticize. Cantillon Iz areziered one of the influential writers of the time; his populatak tarnght derives from his economic theory which was largely neorierosetilist in neture.

Centilion saw land as the ultimate source of all wealth for sosetr. Labor's role in creation of wealth was in giving "the form $2 z$ velitin to products of land and water. Cantilion regarded man's 2 aty to obtain subsistence as conditioned by the degree of access, both diaset and indirect, to land. Land was unequally distributed Escangs fer could own land; not because some dominated others per se, bri Jeczese the natural tendency was to see distributions move to concertretion in a few hands; even if equal distribution were the

$$
\text { 30 Epengler, pp. 53-56. } \quad{ }^{31} \text { Tbid., Ch. III. }
$$


original starting point, unequal distributions would eventually appear (by nature). Accordingly, society was separated into classes. The landless and propertyless were dependent for employment and subsistence upon the owning class, with the minority owning class therefore controlling actual and potential demand for the labor of the landless. As a result, (1) the land owning minority constituted the major primemover of the economy, and (2) population growth was regulated by the above conditions. More specifically, population growth was conditioned by (a) volume of population, (b) distribution of population, and (c) standard of living of the classes of the population. The potential supply of subsistence depended upon the extensiveness of agricultural productivity, the type of crops raised, and the efficiency of cultivation. Thus, the potential supply vis-a-vis the actual supply was governed ultimately by the will of the minority to produce subsistence, and to release produce for consumption by the landless majority. Thus, if concern was for population growth, agricultural output would be maximized. However, with concerns for other things, namely luxuries, land was diverted from agricultural production for such "conspicuous consumptions" as game preserves, gardens or other like expressions; and population growth would be discouraged because actual quantity of subsistence was therefore reduced, or at least not increased, and because prices subsequently rose. Thus, Cantillon recognized that population growth was affected by availability of means of subsistence in a more systematic and theoretical manner than most others of his time. Also, some indications exist which suggest that Cantillon regarded the potential for population increase to be geometrical in 
nature, but checked by the level of subsistence.

From the above, it appears clear that Cantilion was anticipatory

of Malthus. Cantillon did not consider population-food supply relationships as principal factors regulating population. He thought the natural and constant stimulation to population increase rested primarily in employment. As a result, in addition to seeing Cantilion as a preMalthusian, he should be considered a pre-Marxist as well.

In addition to the above, Cantillon considered the impact of international trade on population growth and the impact of wages on same. His views on the former do not bear significantly on matters of this study. Some points concerning the latter do hold some importance. While noting that wages fluctuated inversely to number of population in the laboring class, he also noted some indirect interactions between population and wages. First, migration played an important role in distributing the population over the land to places of need, where wages were higher in places of need stimalating movement; although need for marriage age persons also stimulated migration. Second, low wage levels acted to check population increase by (1) discouraging formation of families until they could be supported, and (2) encouraging migration until financial reserves had been saved to permit formation of family. These points are important because they anticipate Malthus' discussion of "intermediate checks" and because they partially anticipate Marx's emphasis on the fluctuation of wages and its impact on population. 32

$$
{ }^{32} \text { Ibid., pp. 113-28. }
$$


Honoré Gabriel Victor de Riqueti, Comte de Mirabeau (1715-1789), Etienne Bennot de Condillac (1715-1780), and Germain Garnier (17541821) were all strong followers of Cantillon. Mirabeau is interesting because he shifts loyalties later in life to follow Quesnay and may be viewed as another who overlaps Malthus and Marx because of this shift. Condillac was a strong follower of Cantillon, thus another who overlaps Malthus and Marx. Garnier is a late 18th century disciple of Cantillon whose impact comes from tying together ideas advanced by Cantillon, the physiocrats, and Adyin Smith (Garnier translated Adam Smith's Wealth of Nations into French and he attempted to show that Smith embodied many of the ideas of the physiocrats in his work). Again, Garnier is another who overlaps Malthus and Marx as a result.

To briefly summarize, the school arising from Cantillon provides a series of thinkers who combine the natural law perspective, largely implicitly, in articulation of the Malthusian relationships between population and subsistence, but considering population-wage relations, and population-standard of living relations as more influential in affecting population growth than availability of food supply. As a result, this school uniquely combines some ideas which anticipate both Malthus and Marx.

Physiocrats. The principal theorist of the physiocrats was Francois Quesnay (1694-1774) whose influence was perhaps greater than Cantilion's on population thought of his time.

Quesnay stressed agriculture as the primary industry of France and the sole industry on which the economy should be founded. Quesnay differs from agrarians on this point in that agrarians did not question 
the merits of contimiz popolation increase; Quesnay and the physiocrats rejected the jdea suggesting population increase was not always healthy, i.e. apter a point the commanity suffers because of continued population increase. Inplied in his thought is the view that limits to food apply ari other factors wight lead to this suffering.

Quesney pot Porkerd Pour propositions which he tried to prove: (1) natural power flowed from other sources than mere numbers of people, (2) growth of nationa? wealth depender upon expansion of agricultural pome of wealtin, (3) population growth conditioned growth of wealth 2 ese then growith of wealth conditioned population growth, and (4) whaterer increased the income of agricultural production tended to augment both $8 i z e$ and $z \in I l-b e i n g$ of the entire population.

The pirst poopzition rested on Quesnay's belief that numbers did not cause wers; revemie, ieing the source of state power, was the principal cazas of war. (Coesnay advanced this position when mercenaries were a pretaient phenomenon and "buying an army" was easy, making revenue of greater importance to ability to wage war than actual nationel popalation eize.)

The remeining three propositions were supported as follows. Population not Gily was riewed as increasing in consequence of progress in wealth, bat at tiases ae tending to outstrip wealth and subsistence. Quesnay was exere that maibere had a bearing on the creation of wealth, but even when auch abjesione were made, Quesnay considered population growth to be a regult of, not a cause of, wealth; i.e. wealth conditioned growih of popalation, men perpetuated wealth, but wealth came first, then ton increased it. Ouesnay said, "everywhere population 
surpasses opulence; it is wealth that maltiplies wealin and aen; but the propagation of men always extends beyond that of wealtin. nj3 Tre creation and growth of wealth and the growth of population jepresded upon progress in agriculture, "not so much because agriculture edpplied subsistence to men and materials to nonagricultural traies, bat rather because agriculture alone yielded a net product." Foretes, tre explanation of how or why agriculture yielded a net product is not articulated. Labor in nonagricultural trades did not yield a net prodact because the monetary value of its product could not gquai ite monetery costs. Labor in agriculture, by contrast, produced a net prodict, "a monetary sum, or 'value' in excess of the monetary experaes entailed in the creation of agricultural products." 34 conseguentiy, popiation growth (and the basis for making wealth) depended upon tie progrese in agriculture. Hence, population was not merely dependent apen the progress in agriculture. Hence, population as not merelj dependent upon the creation of subsistence but upon the degres of prosperity in agriculture. Finally, population growth did not alweys and everyraere increase in proportion to the creation of wealth. Cascks on poplation could affect population size either by making population too large or too small. Wages could hover at the subsistence letei or at a confort level; if at the former level population would be checked. Drpenditures could be either agricultural or nonagricultaral; is tise latter, population would be checked.

Some additional points on checks to population increase, optinrom

$$
{ }^{33} \text { Tbid., p. } 177 .
$$


population, and population-wage relationships may be noted. Quesnay and the physiocrats saw four categories of checks to population: (1) ultimate checks, including 2 ll conditions which prejudiced progress in agriculture and the augmentation of net product, (2) intermediate checks, including policies which were unfavorable to agriculture, e.g. urganization, manufacturing, and/or luxury consumptions, (3) miscellaneous checks, including factors which favored emigration and not immigration, and (4) immediate checks, including conditions conducive to mortality or prejudicial to natality, e.g. disease, pestilence, and most all other Malthusian preventive checks. The first of the four categories was heavily emphasized while the fourth category was given almost no discussion. Thus, it would be pushing things to say physiocrats were strong predecessors of Malthus.

Quesnay foresaw possible upper limits to population increase; a point might be reached where further growth would be detrimental. Hence, he thought optimum population size should be established; such a state would permit comfortable standards of living instead of mere subsistence. 35

Physiocratic wage theory follows from demographic thought. The physiocrats posited a "normal" level of wages based on pecuniary costs of living at which wages tended naturally to hover. This normal level turned out to be about the lowest possible level. Lowness of wages was produced by great competition for work. When wages rose above this normal level it was due to scarc "y of workers in a particular

$$
{ }^{35} \text { Tbid., pp. 173-90. }
$$


occupation. Physiocrats regarded the tendency to keep wages low to be desirable although no explication of reasons for this view were advanced. The physiocrats did rule out pressure from either an external or intemal industrial reserve army as a basis for wages remaining low because (1) technological progress did not augment the ranks of the unemployed, and (2) state or municipal support of the able-bodied idle cause many to aroid work, thus diminishing the effectiveness of competitive processes. The best analysis of the physiocratic thought on why they regarded wages as remaining low cites the reason to be found in physiocratic population thought; i.e. the procreative potential of man kept downward pressure on wages.

Relative to their advancement of thought on population, the physiocratic thought on relations of population to wages is not extensire. Neglect of the causes of unemployment and failure to make a broad articulation of how the procreative potential of man served to press wages down are two points the physiocrats failed to consider rigorously. The view is offered by Joseph J. Spengler that such failare stems from the definition of their purpose which governed their efforts; namely, to repopulate France, reorganize the French economy to maximize agriculture, and to identify key relations which affect national strength, and not to advance theory on population and wages per se. 36

The Philosophes. Spengler notes that the Philosophes as a school were giving expression to the aspirations of the 18 th century ${ }^{36}$ Ibid., pp. 202-11. 
bourgeois class as it emerged. The Philosophes were unlike the physiocrats, or Cantillon and his disciples, in that much diversity of focus appears in the school. Three subgroups appear in this school; the first concerned itself with population couched in a political focus and included Charles Louis de Secondat, Baron de Montesquieu (1689-1755), Francois Marie Arouet, or Arouet de Voltaire as he called himself, (1694-1778), and Abbé Raynal (1713-1796); the second group focused on biological versus cultural determinants affecting population, with Georges Louis Leclerc, Comte de Buffon (1707-1788) and his followers adrancing this position; the third group included the utopian theorists of progress, Abbé de Saint-Pierre (1658-1743), Claude Adrien Helvétius (1715-1771), Le Marquis de Chastellux (1734-1788), and Marie Jean Antoine Nicolas Caritat, Marquis de Condorcet (1743-1794).

Montesquieu stressed cultural factors affecting population; polygamy, spread of Christianity and its emphasis on asceticism, particularly in marriage, and prohibition of divorce, celibacy, modern slavery checked growth; standard of living affected by the nature of government, liberty promoting fecundity, could either stimulate or depress population growth. Economic factors also checked population growth; e.g. trade and commerce, modes of agriculture requiring many workers transformed by technology to reduce labor needs, unequal division of land, inefficient use of resources. Ultimately, availability of subsistence governed increases in population. Voltaire and Raynal saw population checked by food supply; Voltaire going so far as to regard the relationship a general law. Raynal also thought the concentration of property ownership into the hards of a few led to 
mass poverty.

While Malthusian anticipations can be noted in the above group, Buffon and his followers, John Brückner (1726-1804), Baron F.M. von Grimm (1733-1807), and Abbé Theodore A. Mann (1735-1809), appear to be more significant predecessors of Malthus. Buffon thought population to be relatively constant over the long-run; fluctuations in size were a short-run phenomenon. This long-run constancy Buffon thought due to the tendency for the conditions of support to remain constant. Put more systematically, Buffon thought (1) man's sexual drive was instinctive and not subject to rational control, (2) preventive checks were without long-term influence on numbers, or the standard of living tended to remain constant (implied is the notion of living standard being the lowest possible), and (3) because of (1) and (2), numbers adjusted to available food supply (implied to grow slower than the potential for increase in the population). Brïckner, Grimm, and Mann all agreed that population growth tended to be faster than growth of food supply. Brïckner expressed it thusly: that the "Iaw of multiplication" balanced numbers to available subsistence, and terrain occupied; Grimm emphasized the tenacity of man's procreative capacity; Mann noted population increased in an indefinite progression while food supply was limited by the productivity of the soil. In addition to this strong Malthusian emphasis, Grimm added the view that misery was not, as thought, a check to population increase. Looking at classes in France, Grimm pointed out that the most numerous class was the most miserable class; namely, the laboring class; which contrasted with a small minority who were either very wealthy or endowed with a small 
fortune. As a result, Grimm saw only a minority who had cause to regulate growth, i.e. the wealthy, out of fear of burdening themselves with children and family cares, while the majority of people, living miserably, had nothing to lose by increases in misery from increases in numbers. Net increases in the numbers of the laboring class were the result of (1) mortality rates not keeping pace with fertility rates, and (2) the abandon, or unconstrained yielding, to natural sexual impulses caused by the apparent hopelessness of their miserable lives. Saint-Pierre was one of the first to develop the concept of progress in knowledge as an element of human progress toward social perfection. Saint-Pierre saw progress as indefinitely extensible; thus population was not to be feared. Helvétius was concerned with the impact of population growth on the realization of the greatest happiness for the greatest numbers. Apparently indefinite increases in population did not serve utilitarian ends; wages were depressed because increased numbers meant increased competition in the labor market. From a demographic angle, Helvétius did not regard economic inequality and the resulting exploitation of labor to be more significant regulators of population than physical limits to increase, such as lack of food. Spengler notes that Helvétius appeared to recognize Marx's principle of the industrial reserve army in his discussion of the tendency for population to function as a depressant to wages. 37 In contrast to Helvétius, Chastellux thought population growth was an index of human happiness. Chastellux focused upon the merits of progress, considering

$$
37 \text { Ibid., p. } 246 .
$$


it to be indefinitely continuing because reason had triumphed over old ideas, knowledge had accumulated, and man was nearing perfection. Accordingly, Chastellux thought mass misery was not a perpetual condition born of population growth pressing against limits to subsistence. The limitation on population of food supply could be overcome by continued progress. ${ }^{38}$ Condorcet amounts to the logical extreme concerning belief in progress. His views were severely utopian. His advocacy of his utopia was equally extreme. He thought human society would progress to a state where pure equality existed and all problems were erased. Accordingly, Condorcet rejected views which considered population a problem. 39

The Nonphysiocratic Economists. A number of thinkers were Iumped together under this mbric, all having one or another disagreement with physiocrats in common. Two are of importance for this study. Anne Robert Jacque Turgot, Baron de I'Aulone (1727-1781) is important because he considered charity as a hindrance to the poor, essentially for the same reasons as Malthus thought. The only responsibility the state had to the poor was to see that employment was available. Jean

38 The Marxist flavor of Chastellux's writings appears in his belief in the movement of man to perfection, with reason functioning as the tool for relief of population pressures from limits to subsistence. Spengler ( $p .257 \mathrm{n}$ ) cites $\mathrm{W}$. Stack as considering Chastellux a forerunner of Marxism because he anticipated Marx's concept of historical development, his materialistic interpretation, and "his whole theory of surplus value."

${ }^{39}$ Condorcet's philosophy is summarized by Howard Becker and Harry Elmer Barnes, Social Thought From Lore to Science, (New York: Dover, 1961 ), pp. 473-77. See also, J.B. Bury, The Idea of Progress, (New York, Dover, 1955), pp. 202-16. Discussion of the Philosophes was from Spengler, pp. 212-57. 
Herrenschwand (1728-1811) more than most of his time was truely a forerunner of Malthus. Herrenschwand saw no inherent limit to man's procreative power, and considered growth regulated by availability of food supply. Herrenschwand saw three main stages of human economic evolution: hunting, pastoral, and agricultural. In each stage, population was limited by food supply; with a key difference between each stage being the ability to produce food supply. Each stage was a progressive improvement over the former, with complexity increasing from stage to stage. By the agriculturel stage three forms of society were existent: (1) absolute agriculture, where the economy was divided into self-sufficient units where maltipication of population to limits of each unit could occur; (2) slave agriculture, where slaves produced for bare subsistence and the free popalation could turn to manufacturing and hence create luxuries for itgelf; the size of the slave population was fixed by subsistence supply while the size of the free population was determined by the volume made arailable to it by work of the slaves combined with what net gain was garnered from trade of manufactured products abroad; in both cases, Iimits were attached to population growth-slaves limited by subsistence, free population limited by net product; (3) free agriculture and manufacturing, where the total population was fixed by total supply of subsistence.

Apparently, Herrenschwand considered population problems to persist in each society, regardless of its production base. Concerning the relation of population to wages and employment, Herrenschwand noted a staged process relationship. Stage one found moderately progressive prosperity, when "capital" exceeded "labor" and wages exceeded 
subsistence: Stage two found arrested prosperity, when capital and labor were equal and wages were at a subsistence level. Stage three found retrograde prosperity, when the opposite of stage one existed, namely, labor exceeded capital, and wages were below subsistence. Population growth occurred only under the first condition; growth was rapid and in need of no stimulation, i.e. encouragements for population growth in the form of immigration, inducements to marry were not necessary. Such encouragements were necessary in the second and third stages, but even with such inducements, growth in these stages was temporary. 40

The Extreme Antiphysiocrats. This group of writers have extreme opposition to one or more of the physiocratic principles in common; from pre-Marxians to those who advocated primitive social structure as the most desireable social form, to anti-capitalists who did not antic1pate Marx are found in this group. The writers of concern to this study include only two who significantly anticipate Marx as well as Malthus; specifically, M. Necker (?-?), and S.N.H. Linguet (1735-1794).

For Necker, happiness was as important a pillar to sirengthening the state as wealth and population. When he looked at population, it was with happiness in mind as a criterion for determining merits of continual growth. Necker concluded that too much population growth would run counter to happiness, and hence thought it should be limited to the realm where it contributed to happiness. However, he did not see much trouble with continual population growth because he thought 40 Spengler, pp. 290-96. 
wealth would accumulate at least as rapidly as population, preventing any decrease in happiness. Apparently by the close of his life, Necker had some misgivings about the above for he noted that population had increased in his lifetime despite the persistence of widespread misery. Necker considered the relation of population to food supply. Says Spengler, "in his treatment of the capacity of man to multiply up tö and even beyond the limits of subsistence, Necker out-Malthused Malthus, thereby contradicting the view that population growth was evidence of felicity. " 41 Spengler quotes Necker as saying,

The Impetuous attractions that nature has put between the sexes, the love that she inspired in them for the fruits of their union, are the cause of the multiplication of men upon the earth; these sentiments dominate the poor like the rich; no law can be opposed thereto, and if it were possible, it would be barbarous. Every sensible being likes better to share bread with his helpmate and his children than to live alone upon more varied foods; it is thus that population spreads itself, and in spreading itself, it increases in an inevitable manner the number of miserable. 42

The compulsion to procreate, thought Necker, was so great that even poor people did so; against pressures checking growth (war, iniquity, heary taxes, propensity to celibacy, enfeeblement of the human organism, poverty, infant mortality, and depravity of customs) population inevitably grew. Necker thought populations of countries could only multiply to the limits of subsistence produced by the countries. Necker noted that there were other forces operating which checked population growth before it reached ultimate upper limits of lack of food supply. He identified both preventive and positive checks

$$
41 \text { Ibid., p. } 325 .
$$


which cut growth before it surpassed the sum of subsistence. His preventive and positive checks were roughly equivalent to those noted by Halthus.

Hecker pas pesimistic about the future of population growth. He thought the sexual urge would triumph over positive and preventive checks so long as agriculture and industry did not retrogress; hence depopulation would not occur if agriculture and industry were maintained; hence the trend toward increasing misery.

In discussion of population-wage relations, Necker more specificalIy anticipated Marx. Furthermore, his discussion of wages introduced the role of exploitation as an influence over wages for the first time among writers of the 18 th century. The amount of exploitation permitted by 1 aws and institutions affected the process of wages adjusting to popalation supply. Necker emphasized class struggle as an important factor apfecting the condition of population; advocating government intervention on behalf of the working masses to reduce the degree of exploitation (and, implicitly, to upgrade the level of happiness in society).

ilages, Hecker thought, varied according to class and to talent of workers, where wages were highest in industry and lowest in agriculture. Hages for common labor varied according to degree of exploitation of the proprietor from a sum sufficient for individual subsistence to a gum sulficient to support a family. Furthermore, factors (biological, physical, and institutional) combined to weaken the bargaining power of the common worker. Population growth increased the number of workers relative to the number of proprietors thereby intensifying 
competition for employment, thereby reducing the level of wages. Effects of population growth in different cIaszez also iniensified by laws and institutions the concentration of land omerabip; namely, the working class was always too poor to buy lard on tas one hand, and too numerous to raise wages enough to improve their ierei of living on the other hand, while the proprietary class did not fare a popolation problem, and, through keeping wages low, covid accomiate profit and thereby buy more land. Necker concluded that tre power of the property owning class was so great, and the condition of the working class so weak that workers were virtually slaves. 43

Iinguet essentially is a disciple of Necks: $3 n$ id consideration of him would largely be a reiteration of Necker.

Pre-Malthusian and Pre-Marxist French iriters. Fron the preceding discussion, it should be evident that within the diveres population thought of France appeared strong strains of predecesgors of Malthus and Marx. The pre-Malthusians for the most part anticipated most of the preventive and positive checks; the geometricei rate of population increase versus less than geometrical growth of 8000 supply. Warx was anticipated more modestly, or inextensively, then lestivu but important elements were foreshadowed; namely, "surpluz-ralue" and the role of class struggle and exploitation in population matier.

Predecessors of Malthus Included Cantilion, Gamier, Quesnay, and the physiocrats, Montesquieu, Voltaire, Rayal, Especially the second group of Philosophes, including Buffon and his Eoilowere; all of the ${ }^{43}$ Ibid., pp. $324-33$. 
above recognized limits to population growth born of food supply. In addition to anticipating the population-food supply relation, Turgot anticipated the Malthusian view on charity. Likewise, Herrenschwand ranks as especially significant for recognizing positive and preventive checks plus the view that misery was born of the poor not regulating their reproduction. Necker holds the auspicious position of significantly anticipating both Malthus' preventive and positive checks, and Marx's emphasis on class struggle and exploitation affecting population.

On the Marxian side, most anticipations of Marx were vague. Law saw relations between population and employment; Cantilion partially anticipated Marx's thought on population and wages, as well as the importance of class structure in the question of overpopulation (making Cantillon, Iike Necker, a precursor of both Marx and Malthus); Condillac noted population as dependent upon production instead of the typical focus on subsistence per se; Garnier treated population-wage relations similar to Marx; Grimm noted that misery did not check, but stimulated population growth; Quesnay made some vague anticipations of Marx in the physiocratic wage theory; Helvétius saw wage-population connections somewhat as did Marx, but, more importantly, saw the outline of the industrial reserve army before Marx; Chastellux anticipated the principle of surplus-value; Turgot saw the fluctuation of wages related to population growth as well as capital accumulation's impact on wages and population; Herrenschwand saw population-wage relations, as well as the importance of a historical view of development; and Necker anticipated the principles of overpopulation as a function of exploitation, saw wage manipulations and their impact on population, stressed 
the importance of class struggle, and implied an industrial reserve army in his reasoning. Linguet deserves inclusion as anticipating Marx also because he was a disciple of Necker.

\section{Germany}

Mercantilism lasted longer, and remained more influential, in Germany than elsewhere in Europe virtually through the first three quarters of the 18 th century. The last quarter of the 18 th century found a sudden shift in emphasis to a Malthusian perspective. There was no slow shift from mercantilism, no period of post-mercantilist multiple schools. The exception to the patter is Sussmilch, who, while a mercantilist, emphasizing populousness, anticipated Malthus and utilized statistical tools in the formulation of his thought, considered the first comparatively well-developed theory of population. Thus, in noting Germany for the post-mercantilist period, it boils down to Sussmilch and predecessors of Malthus.

Sussmilch. Johann Peter Sussmilch (1707-1767) wrote his theory of population in 1741. He tied together statistical work on population with principles of natural law in his theory. The objectivity of his theory is colored by his overt theological moralism which dominated his perspective; despite his studies of population, he favored maximizing populousness for religious reasons.

Sussmilch used the mortality and birth tables of Graunt and Petty, as well as tables by obscure Dutch scholars, Struyck and Kersseboom, and an obscure Swede, Wargentin. 44 Sussmilch thought the

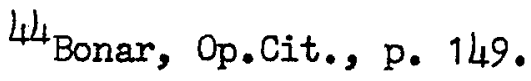


birth rate was always normally greater than the death rate; the difference between birth and death rates was the cause of population growth. The only foreseeable limit to continual increase was fixed by the size of the inhabitable parts of the earth; although population growth was checked by other factors more immediately influential; namely, such preventive checks as observed by most students of population of the 18th century, e.g. war, famine, pestilence, plagues. Efforts by Graunt and Petty to estimate population doubling times were in error, thought Sussmilch, because they had neglected to give adequate importance to variations in ratios of population increase between cities and rural areas. Sussmilch's estimation of a normal period of doubling, avoiding the mistakes of others, was 100 years; of course variations by country and region were evident. If a fair portion of the earth was assumed habitable, Sussmilch estimated optimum population for the planet at four or five billion. If increase took place in rates as he estimated optimum population for the planet would be reached in 200 years. Sussmilch emphasized that his were estimations which could change since agricultural and mechanical improvements would probably continue making increases in subsistence, hence, population, possible. While anticipating Malthus' though, he did not share Malthus' pessimism; the taint of theological moralism compelled him to embrace a blind faith view fo the merits of populousness. As a result, his theory of population is less significant than it might have been. 45

Pre-Malthusians. The predecessors of Malthus in Germany in the ${ }^{45}$ Ibid., Ch. V; Stangeland, pp. 213-23. 
last quarter of the $18 \mathrm{th}$ century included Christian Wilheln ron Dosm (?-?), August Ludwig Scholoezer (1735-1809), and Justus woser (17201794). All three recognized the view that popalation was Iizitis by food supply, that population tended to increase faster than iooi eapply, that the result was an increase in the misery of the lower clazaga. Dohm and Scholoezer confined their anticipations of MeIthas to popiletion-food supply relationships while Moser anticipated thost of tas positive and preventive checks to population explicated bo Usifns, taking, also, Malthus' moralistic rejection of birth controi az conducive to increases in vice. Generally speaking, the posi-nescentilist period in Germany was quite placid and comparatipeiy reiaried compared to England and France.

Two Additional Predecessors of Malthus

Before making concluding remarks, two aditional pre-Waltrusians need to be noted. The writers are Italians and did not pit in the general structure of the chapter but bear upon the argunenta ziranced in Chapter V. The first is Giovanni Botero (1540-1617), the esconi $\pm \varepsilon$ Giammaria Ortes (1713-1790). The former writer thoroughly aniicipated Malthus but never received recognition by writers of the 17 th and isth centuries, nor by Malthus. The latter writer was noted by dare with Marx pausing to stress Ortes' importance as a scholar. Considering Ortes as a pre-Malthusian, this has great importance in the arginent in Chapter $\mathrm{V}$.

Botero recognized limits to population growth, incloding iooi supply, war, and pestilence. He thought the world to be alwess suffering from such conditions because the potential to procreate was 
stronger than the potential for generating adequate food supply; thus the persistence of appearances of overpopulation. Botero saw the means of increasing population lying in number of births, preservation of infants, and prolongation of life. Botero, despite observing negative aspects to population increase, thought size should be maximized. 46

Ortes saw a proportional relationship between population increase and availability of means of subsistence such that the former was limited by the latter. Ortes considered population increase to be geometrical. He saw checks to population growth in lack of food. Unlike animal populations, Ortes thought human populations had an additional means of population control in the exercise of prudence. Thus, Ortes considered celibacy as beneficial in the regulation of population. However, prudence and lack of food were not the only checks to population growth; misery of poverty, slavery, or forced labor were other checks because they discouraged marriage and encouraged vice. Despite checks, Ortes concluded that human population growth tended to remain geometrical against a much slower growth rate for increases in means of subsistence. Accordingly, regulation of population had to be made rationally, with reason, according to times and seasons to prevent the negative consequences of overpopulation. 47

\section{SUMMARY OF THE CHAPTER}

Population has been a subject of concern by human societies since the earliest societies. While early thought was admittedly vague, i.e.

$$
{ }^{46} \text { Stangeland, pp. 334-37. } \quad 47 \text { Tbid., pp. 105-07. }
$$


agrisernetical, a continuity may be ovserved through the history of ppostion thought. Such basic questions as what makes population Ext athet are the consequences of growth? how can it be encouraged and خs:ruraged? is there an optimum size the earth can support? were asked $\equiv \pm \equiv \equiv-1 y$ as the Greeks and carried forward thereafter. Indeed, many of yescrers heve been the same through the centuries; thus the propose sor encouraging population growth during the mercantilist period erea todey resemble highly those advanced by Greeks and Romans. Wez zanged the most through time was determinations of the relative imovence of one or another factor, e.g. early emphasis upon food 2y-py engmented with discussions of wages and employment, which by LE Jin centary took precedence over food supply as key factors בEserting poprlation growth for some schools of thought. If the goal was to identify significant trends running through the Ierelopmezi of population thought, three principal trends would be (1) Eusaration of observed relationships and accumulation of observations, (2) iartification of interrelationships between population and other Eatres, i.હ. economic forces, standard of living, the goal of building Eatani sirength and wealth, and international trade, and (3) the Evvercemeri of a quantitative mode of inquiry and analysis, being the Eerelopment of statistical tools applied to demographic studies. Fy closely looking at the 18th century, in particular, a stucture of relationships had developed by the time of Malthus. Jymlation increase was considered affected by availability of food. Exive tncrease was considered affected by economic conditions, price $2 \pm$ Eson, trade, state of production both agricultural and 
manufacturing, and by natural checks including war, vice, and sociocultural checks like luxury and standard of living. The considerations of population separated into pro-natalist, optimum population, and Malthusian categories, and some modest anticipations of Marx.

It would be difficult to conclude that demographic thought was evolving rapidly along a set path through the 17 th and 18 th centuries. There was a proliferation of schools which, by the close of the 18 th century, coalesced into a general agreement about population which was largely anticipatory of Malthus, ilost preventive checks had been specified. Employment and wages, and other "intermediate checks" were specified and the lion's share of writers agreed on relations of population to all these factors that were entirely consistent with what Malthus wrote. Consequently, it is entirely fair to say the content of Malthus' work did not contain any starting new findings, but built on well-established principles of preceding centuries. 
CHAPTER III

\section{MALTHUS}

As noted in the closing remarks of Chapter II, by the time Thomas Robert Malthus (1766-1834) wrote his famous (some say infanous) essay on population the components of its structure had been long and well anticipated. It is the case that Malthus did not say anything new in his essay on population. Yet his essay caused a great stir not accomplished by preceding writers. Why did this occur? Most consider the reasons to include social, political, and economic conditions of England when Malthus wrote, and the way Malthus used the "principle of population" to explain conditions in England. Considering the auspicious place Malthus is afforded in the history of demography born of his success in writing about population, and considering the fact that Marx's thought on population is formed substantially as a critical reaction to Malthus, it is important to look at Malthus and understand conditions surrounding him as well as his thought. To do this, some considerations of (1) his biographical history and some points on the history of England during his lifetime, (2) his thought on population, including explication of his views and Joseph J. Spengler's reconsideration of Malthus, and (3) his place in demographic history, involving a critical assessment of his thoughts, will follow. 


\section{BIOGRAPHICAL AND HISTORICAL BACKGROUND}

Malthus' thought appears to be more profoundly influenced by his personal history, including family affiliation and occupation, and historical events in England and France than by many schools of thought on population in England and the rest of Europe. This by no means implies that Malthus was not influenced by other's thought on population, for clearly he was, but merely that it played a comparatively less significant role in stimulating him to write.

Thomas Robert Malthus was the last of two sons in a family of eight. His father, Daniel Malthus, was friend to both David Hume and Jean-Jacques Rousseau. Thomas was educated privately and entered Jesus College, Cambridge, in 1784 at the age of 18 , and graduated in 1788 with highest honors. 1 The year of his graduation saw Malthus taking Holy Orders as well. In 1793 Malthus assumed a fellowship at his college, Jesus College, where he intermittently resided until 1804. In 1804, Malthus married (38 years of age at the time). In 1796 he accepted a curacy at Albury and two years later published, anonymously, his first essay on population, titled An Essay on the Principle of Population as it affects the future Improvement of Society, with Remarks on the speculations of Mr Godwin, M. Condorcet, and other Writers.

${ }^{1}$ Malthus graduated ninth Wrangler, the Cambridge equivalent of first class honors in mathematics. Thus, Malthus was a superior mathematician for his time, hence familiar with the quantitative techniques of demography. He was also familiar with Newtonian physics and widely read on history. To the question, was MaIthus aware of other population thought of the time? therefore, it is best to presume that he was. See Anthony Flew, "Introduction," Malthus: An Essay on the Principle of Population, (Harmondsworth, Middlesex, Fingland: Penguin Books, 1970), pp. 8-9. 
Typically, the shorthand title used for this work is The First Essay. In 1803 a second edition was issued; it was longer, more detailed, and Malthus attached his name to it. In fact, the second edition was qualitatively different from the first and is typically referred to as The Second Essay. The second edition underwent relatively minor revisions in its seven editions, the last penned by Malthus in 1826. A summary view was written by MaIthus for a supplement of the Encyclopaedia Britannica in 1824, completing Malthus' specific writing on population. During the time of his life Malthus did make other points on population in his Principles of Political Economy. As will be seen, Spengler notes that to fully appreciate the entirety of Malthus' thought on population, these additional points must be included. While he wrote and stirred the people of England by his work, he made some occupational changes. In 1805 Malthus accepted appointment to the college established by the East India Company for the training of young men entering its service. He remained in this position the rest of his life.

If this is the personal background into Malthus, what of the background on England in which the essays on population caused such a stir? The First Essay was a polemic in reaction to the optimism of Condorcet and William Godwin (1756-1836). ${ }^{2}$ Condorcet's ideas were written while hiding, facing the death sentence. He was an active influence on the initial phase of the French Revolution but later fell out of favor with the Jacobin extremists who pursued him, and eventually

\footnotetext{
${ }^{2}$ An explication of Godwin's views is found in Becker and Barnes, Op.Cit., pp. 477-81.
} 
captured and executed him. Condorcet fervently believed in a natural order of progress which would inevitably lead to a utopian society on earth where racial and national antagonisms were dissolved along with sexual, wealth, and opportunity inequalities. William Godwin, the English counterpart to Condorcet, found great inspiration in the French Revolution. Godwin had similar utopian dreams based on a view that progress was bound to carry man upward to such a utopia where there was no war, crime, injustice, or need for government.

Malthus' father was a believer in the visions of Condorcet and Godwin. In debate with his father, Malthus initiated his interest in refuting such utopian views, regarding them as based on no sound evidence.

'There was more to Malthus' concern than merely respectful debate with father. The age in which Malthus lived was one of transition, in terms of ideology and in terms of actual social change. Spengler thinks three doctrines, or sets of beliefs, were converging in the latter part of the 18 th century and Malthus' essay on population was a product of the convergence. The first doctrine was that of progress; "man was making progress, technological and social; and that, since progress is cultural in character and culture is cumlative, progress must, ceteris paribus, be cumulating and unencing." ${ }^{3}$ Second, the common man was coming into his own; the beneficiary of the

\section{Joseph J. Spengler, "Malthus's Total Population Theory: A} Restatement and Reappraisal," in Population Economics: Selected Essays of Joseph J. Spengler, (Durham: Duke University Press, 1972), p. 45. Unless otherwise noted, future references to Spengler in this chapter will be to this essay. 
redistribution of economic and political power occurring in that age as well as of the democratic movement that was gaining increasing support. Third, recognition of limits, physical, social, and psychological, to the universe, hence to human behavior was being made. "Efforts to resolve and synthesize acceptably these three somewhat inconsistent sets of beliefs were brought to a head by the French Revolution and the principles it posed," and by a series of factors changing in England; namely, problems with the poor, bad harvests, and fears of the French Revolution, and of actual war with France. 4

Thus, while ideological elements were converging, social changes were having an influence also. Some classes in England looked across the channel at the consequences of the French Revolution with less than eagerness to see the same occur in the motherland. Fears of mass uprisings occurring which would wash away the status quo were of concern to the upper classes. The plight of the poor was worsening during this time period; the English poor laws were failing to relieve the plight of the poor, and Arnold Toynbee noted that when Malthus wrote his essay on population, there had been a series of bad harvests. Corn was not easily obtainable from abroad either making a condition where year after year food supplies did not increase while population size did; the result was increasing misery among the lower classes. 5

${ }^{4}$ Ibid.

${ }^{5}$ Arnold Toynbee, The Industrial Revolution, (Boston: Beacon Press, 1968), p. 91. Toynbee notes further:

"Thus in 1800, when corn was 127s. the quarter, it was clear that the rich could not help the poor by giving them higher wages, for this would simply have raised the price of the 
The English aristocracy feared the worsening of conditions among the poor as a potential ignition of revolution. It was necessary to successfully challenge the merits of revolutionary views.

With such a background operating in England, conditions were ripe for reception of ideas which would explain the difficulties facing England. Into that climate entered Malthus with an explanation-that the root cause of England's problems was the natural law of population growth; that utopian dreams were not realizable; that the solution to problems was found in control of population growth and in revolutionary social change. This explanation was (whether intentionally advanced by Malthus an an apology or merely appropriated for use as such is unclear) advanced by the English aristocracy to rationalize conditions of the times and free themselves from responsibility for the problems; i.e. problems were the result of a natural law and not social management of the ruling class. 6

fixed quantity of corn; therefore, unless population diminished, as years went on, wages would fall because worse soils would be cultivated and there would be increased difficulty in obtaining food. But the period he had before his eyes was quite exceptional; after the peace, good harvests came and plenty of corn; food grew cheaper, though population advanced at the same rate. So the theory in this shape was true only of the twenty years from 1795 to $1815 . "(p .91$.

'Malthus' population theory has been looked upon by many, especially the Marxists, and Marx himself, as a counter-revolutionary answer to the rational movement which culminated in the French Revolution. Was Malthus acturlly a counter-revolutionary? Spengler says:

"Malthus was a counter-revolutionary in that he opposed certain principles associated with the French Revolution and condemned revolution in general. He was a conservative in that he attached great weight to the essentially constant, 


\section{WHAT MALTHUS SAID}

Well what did Malthus actually say in his essays that served to challenge revolutionary views, act as an apology, and yet endear him to demography as a significant figure in its history? This question can be answered by considering the contents of The First Essay and The Second Essay. But to fully cover the totality of Malthus' writing on population, it will be necessary to consider Malthus' other works, chiefly, his Principles of Political Economy. This consideration of Malthus' total population theory was not developed by a modern scholar until Joseph J. Spengler probed Malthus' works with meticulous care. Thus, this chapter will give important attention to Spengler's study of Malthus.

The First Essay

In The First Essay Malthus advanced some theoretical propositions

and less weight to the essentially variable, elements of nature, man, and social relations; in that he stressed the regulatory functions of institutions in general, and not only opposed but also considered very improbable any important change in the fundamental institutional and social structure of English society; and in that he held, and believed it necessary to hold, the individual almost completely responsible for his actions and for his failure to act." (p. 55.)

Spengler goes on to say that Malthus was a conservative because he did not believe man easily transformable into a virtuous being. Finally, Malthus noted that there were no grounds for easy optimism and easy harmonizing of interests; the road of human development was, and always would be, hard. However, Malthus was not a counter-revolutionary because he measured the value of government and institutional structure in terms of its utility. Accordingly, he opposed feudalism and did not hesitate to seek to improve the condition of the common man. Thus, for Spengler, Malthus is a conservative, not a counterrevolutionary, despite counter-revolutionary elements in his work. 
about the nature of population increase. Thereafter, he examined the social problem of poverty and the price of lebor in terns of the propositions. Malthus also advanced thought on denographic theory per se, in which he discussed Hume's examinetion of ancient popalations, Sussmilch's mathematical tables, and Wallace's disclesion of population. Malthus began The First Essay making tio postulates: (1) food is necessary to the existence of men and (2) the pasion between the sexes is necessary and will remain nearly in its pregent eivie.? kalthus regarded his postulates to be fixed laws of nature, unalierable by man; since they had remained unaltered since the inception of knowledge they gave no basis for speculating that they would change in the future. Granting the postulates, Malthus reasoned that "the power of population is indefinitely greater than the power in the eartis to produce subsistence for man." Unchecked, population increased in a geonetrical ratio. Subsistence in contrast increased in an arithretical retion. As a result, a strong check to population growth was iound in the discrepant growth ratios of population and subsistence. The principal manifestations of population so checked appeared to be misery and rice, with the former being an absolutely necessary conseouence oz it, the latter "highly probable;" because virtue could carcei out rice. If, Malthus concluded, the above relationships were true, as as trought they were, then the highminded utopian dreams of the likes of fonciorcet and Godwin were unrealizable because the above laws conditionei a siate where misery was always bound to exist and vice was highly probably bound to

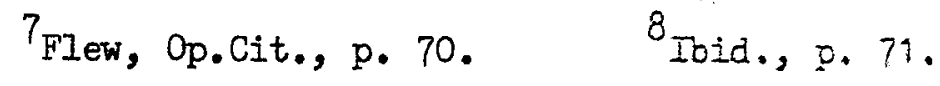


exist. 9 The conditions of misery and vice took on the force of natural law; inevitable, inescapable, inexorable, indefinitely persistent. The above basic checks manifested themselves in multifaceted ways when considering humankind vis-a-vis the animal and/or plant kingdoms. The principal agent involved in complicating matters was the human capacity to reason. Unlike the rest of life, individual humans might resist increasing their numbers by recognizing, through reason, that additional numbers may not be supportable. For the upper classes, concerns, indeed fears, of lower rank by need for supporting additional mouths acted to restrain increase. In the case of the lower classes, fear of being driven into deeper misery, of seeing offspring grow up in rags and misery acted to discourage increase. Through such reasoning Malthus thought individuals were driven to restrain their natural drives to reproduce. But as a result of such resistance to natural compulsions Malthus saw vice increasing.

Malthus thought the above operated in cyclical waves conditioned in the following way: The discrepancy in growth rates of population and food always found additions to the population preceding increases in food. Thus, food available which previously supported X-million mast now support $\mathrm{X}$-million plus the number of new mouths. The result was a decline in the standard of living of the poor. (Implied here is a view that the lower classes reproduce themselves into trouble while the upper classes do not and that social structure inequitably distributes resources such that the upper class survives as usual in

$$
{ }^{9} \text { Ibid., p. } 72 .
$$


the face of scarcity at the expense of the lower classes.) Further, since new numbers were new laborers, the market for labor became saturated, resulting in declines in the price of labor and incresses in the price of food. The result was that the laborer worked harder for the same as before (or less). The difficulty of living brought about a discouragement to marriage because conditions made it a difficulty to support a family. The economic conditions brought about by increased availability of labor and decreased price of labor, plus an environment which demanded industrial expansion encouraged agriculture and industry. Ultimately, with population increase discouraged and food supply increasing, a time was reached when food became abundant again. "The situation of the labourer being then again tolerably comfortable, the restraints to population are in some degree Ioosened, and the same retrograde and progressive movements with respect to happiness are repeated. "10

Malthus suggested that the above oscillation pattern did not follow any necessary time cycle; and it was not easily visible because history was usually history of the upper classes, thus obscuring the real heart of the oscillations, the lower classes. Furthermore, difficulty in observing the oscillations came from intervening variables like the introduction of or failure of manufacturing, greater or less extensive agriculture, years of plenty or scarcity, wars and pestilence, poor laws, technical improvements in production which increased unemployment, and "particularly, the difference between nominal and real

$$
\text { 10 Ibia., p. } 77 \text {. }
$$


price of Iabons, E circunbtance which has perhaps more than any other contributed to sacea tiliz oscillation from common view." 11 Malthus went on to $3 \pm y$,

It $\nabla e \pi$ rareiy iappene that the nominal price of labour uniterealy $2=33$, bat we know that it frequently remains the sane, wite tre zowinal price of provisions has been increastas. Whis is, in effect, a real fall in the price of labour, and dring this period the condition of the lower orders of the commuity mat gradually grow worse and worse. But the iaraes asd capitalists are growing rich from the real cheapnese o2 Labour. Their increased capitals enable them to $=m i b y$ a geater number of men. Work therefore may be olentisti, tat tise price of labour would consequently rise. Bat the wat of fresdom in the market of labour, which occurs

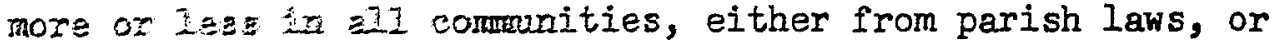
the more gengez cane of the facility of combination among the rlch, ant ite biliculty among the poor, operates to prevent the pree of labour from rising at the natural period, and ti $k=E \bar{z}$ dora zome time longer; perhaps till a year of scarcity, wat the clancur is too loud and the necessity too apparent to be zesisted. 12

de $a$ Tezty, the ceuse of increase in the price of labor was obscrared. Waituma noted that it appeared the case that the rich did indeed controuts to prolonging the conditions of miserable poverty by manipulating the pries op labor with the result being the checking of population latreses becanse of persistent misery. However, (in what Marx regaried az a zationelization which attempted to shift full responaio1116y $20 x$ onditions from the shoulders of the aristocracy) Malthas sugessed taet wat the upper classes did or did not do was ultimately 1rocnzengextial eince "no possible form of society could present the Enoet oonetant action of misery upon a great part of mankind. $n^{13}$ We ony diference in forms of society was that in a

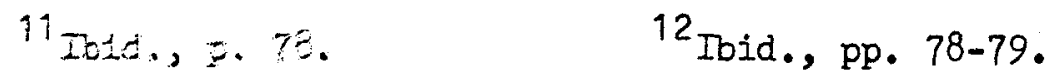


society of inequalities the poor suffer while in a eosety of equality, everyone suffers.

As part of Malthus' effort to provide support for his postula-

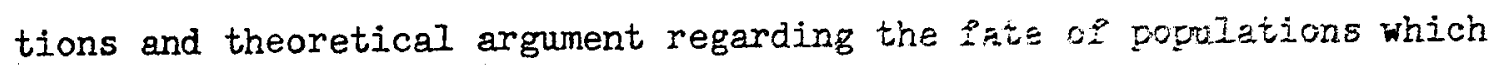
increased beyond limits of subsistence, he examiner. popaletion processes of other times and places; using eqidence wici wa mostly observational, i.e. reports from travelers. Alzo, he considered the Hume-Wallace debate regarding the populousness of arcisat nations, after which he advanced conclusions conceming the netrne of checks to population, which led to a critique of the English poor laws.

After discussing population around the wald /2.E. Walthus looked at population increase for different parta of the vicrij, and for primitive societies and other civilizationa, nanely caina), Malthus concluded that assuming a sufficient extent of territory to include within it exportation and importation, and allowing err variations in the prevalence of luxury, or of "frugal habite," popviation "constantly bears a regular proportion to the food that the earth is rade to produce (emphasis in the text)."14 Based upon the ziore conclusion, Malthus tackled the Hume-Wallace controver $8 y$ regardine the populousness of ancient nations. Looking at the argument adparaed by Eume, Malthus concluded that it was inappropriate for Hume to conclide based on evidence that ancient populations were smallex then populations of his time. Malthus said at best the information pemitsed an observer to infer movement in one or another direction but provider no basie for
${ }^{13}$ Ibid., p. 79.
14 Ioid., 0.87. 
conclusions about actual size. Then, citing information regarding ancient China, where practices of child exposure prevailed, Malthus concluded that Hume was mistaken; that, in fact, population pressed on the means of subsistence then as in Malthus' time. ${ }^{15}$ Now Malthus said that comparing the modern Europe with ancient populations would lead to conclusions that growth was very slow in Europe. However, this did not prove false Malthus' proposition that the passion between the sexes was necessary and would remain nearly in its present state. Indeed, the passion between the sexes persisted as far as Malthus could tell, but two principal checks were operating to prevent rapid growth from occurring. The first check was the preventive check which came from recognition of "the difficulties attending the rearing of a family." 16 The second check was the positive check which came from "the actual distresses of some of the lower classes, by which they are disabled from giving the proper food and attention to their children." 17

15 This conclusion is important because Malthus argued that population had always, and would always press upon food supply such that the problem of population was always and would always be with humankind. The reader is encouraged to keep this point in mind because in the next chapter it will be seen that this is a point Marx denied more or less explicitly when he argued that if production were not incumbered with capitalists appropriating surplus-value, production would not only keep pace with population growth, but would exceed any increase in population thus making the problem of population growth a nonproblem. This is a fundamental point of disagreement between Marx and Melthus which goes to the heart of the debate between them and illuminates the essence of Marx's alternative position.

16 Flew, p. 89. The two checks may be separated in terms of reason. The preventive check implies that reason may be brought to bear to regulate reproduction. Positive checks imply the unconscious inexorable operation of natural laws.

17 Ibid. 
The preventive check operated in all classes, thought Malthus. Men of the highest social rank were checked from marriage and family by a self-interest in maintaining their high standard of living. The highly educated man with but sufficient income for personal maintenance of high class rank resisted forming a family out of fear of seeing his class standing reduced. Tradesmen and farmers resisted marriage for mach the same reason-difficulty in securing adequate livelihood for maintaining an adequate living for a family. In contrast, positive checks seemed to Malthus to be confined to the lowest classes. Apparently citing Graunt's bills of mortality (though no mention of Graunt's name was specifically mentioned) Malthus suggested that infant mortality was clearly highest among the poorest, suggesting the inability of the poor to meet demands of food for their children.

To meet conditions of misery among the poor, Malthus said, England instituted poor relief (poor laws). But, he asked, does poor relief really resolve the misery produced by the above positive check? Recalling that a major cause of misery was an excess number of people relative to availability of food supply, the giving of money to the poor, thought Malthus, would only serve to increase the price of food. To the argument that increased money would spur increased production, Malthus said it might occur to some extent, but the motive for increased production would be limited because with money relief in his pocket, the poor man can "fancy himself" comparatively rich and able to indulge himself in many hours or days of liesure." The result would be a "strong and immediate check to productive industry, and, in a short time, not only the nation would be poorer, but the lower classes 
themselves would be much more distressed...." ${ }^{18}$ So, Malthus concluded, the poor laws did not serve to benefit the poor but instead resulted in a depression in the state of the poor because (1) the poor laws tended to increase population without increasing the food for its support, i.e. a poor man was not discouraged from marrying because children would provide increased relief under the poor laws, and (2) food consumed by the poor through poor relief "cannot in general be considered as the most valuable part diminishes the shares that would otherwise belong to more industrious and more worthy members, and thus in the same manner for us more to become dependent." ${ }^{19}$ Thus, Malthus argued, the poor laws defeated their own purpose. Implied, in the advancement of the position, were two additional points: (1) the outcome was inevitably and necessarily as Malthus stated because the principle of population was a natural law, and (2) the poor, unwilling or unable to control their growth, were ultimately to blame for their plight.

In addition to the above processes which acted to check population increase, Malthus added "vicious customs with respect to women, great cities, unwholesome manufactures, luxury, pestilence, and war" which he thought resolvable into two principal checks, misery and vice. 20

Malthus goes on to build evidence to support his conclusions about preventive and positive checks by probing into the question of the causes of epidemics. With this as a goal, Malthus examined

$$
\begin{aligned}
& { }^{18} \text { Ibid., p. } 95 . \\
& { }^{19} \text { Ibid., p. } 97 . \quad \quad 20 \text { Ibid., p. } 103 .
\end{aligned}
$$


Sussmilch's mathematical tables of mortality, fertility, and marriage as well as Sussmilch's conclusions concerning population dynamics. From these examinations, Malthus is led to conclusions rejecting as unrealistic Wallace's view that overpopulation would not occur until the whole earth was cultivated.

Malthus concluded from Sussmilch's work that epidemics operate to check population growth where crowding and "unwholesome and insufficient food" also contribute to checking not only in their own right but by making epidemics more extensive. Analysing Sussmilch's tables, Malthus observed that declines appeared in regular cycles and periods of most prolific growth occurred in years proceding years of increased death. Using Sussmilch's tables, Malthus advanced some further points:

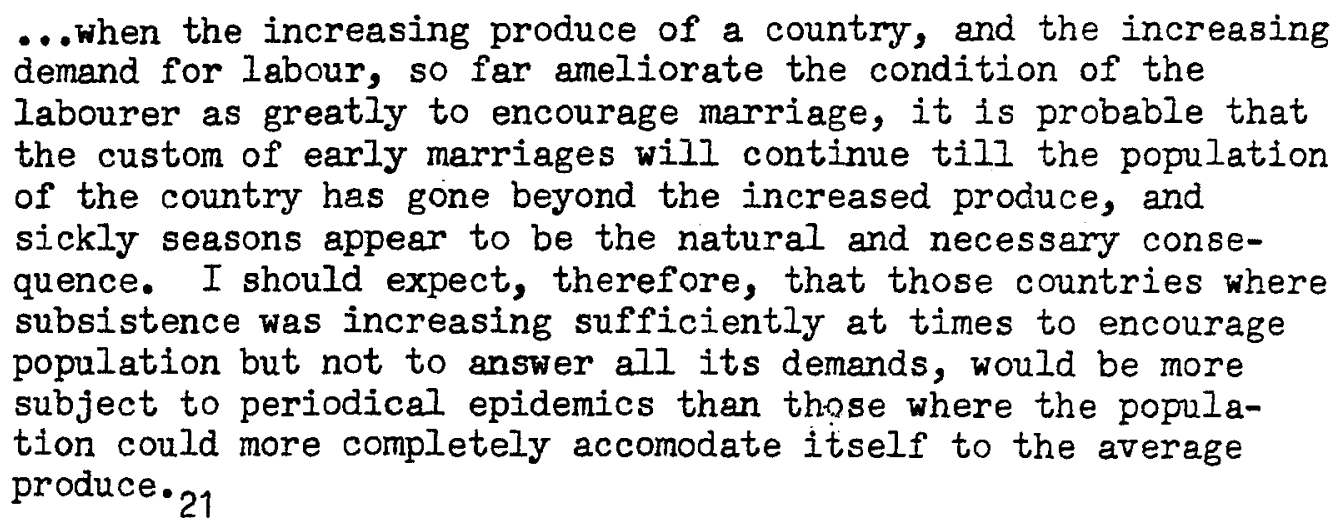

The converse relationship, Malthus said, might also follow. In countries with periodic sickness, the increase of population "will be greater in the intervals of these periods than is usual, caeteris paribus, in the countries not so much subject to such disorders. "22 Thus, "the average proportion of births to burials in any country for

$$
{ }^{21} \text { Ibid., pp. 111-12. } \quad 22 \text { Ibid., p. } 112 .
$$


a period of five to ten years," would appear to be a very inadequate basis for judging the real progress of populations over time. In other words, Malthus thought it not possible to infer from the past what the future structure, or conditions, of the population would be like. ${ }^{23}$ Based on analysis of additional birth and death tables compiled by Price and Short for England, Malthus concluded further: "In the natural progress of the population of any country, more good land will, caeteris paribus, be taken into cultivation in the earlier stages of it than in the later." 24 Still further, a greater proportional yearly increase of food would almost always be followed by a greater proportional increase of population. When population was rebounding from the ravages of epidemics, this proportion might be larger than it otherwise would be. A careful look at England and France showed that their populations had established a balance of births and deaths which served to balance population and food supply through "discouragements to marriage, the consequent vicious habits, war, luxury, the silent though certain depopulation of large towns, and the close habltations, and insufficient food of many of the poor," had served to eliminate the "necessity of great and ravaging epidemics to repress what is redundant." 25

Based on Malthus' study of tables of births and deaths made by<smiles>[124In]</smiles>

24 Ibid., p. 113. Note: Implied in this statement is the law of diminishing returns as a limit to population growth. More on this point will be noted when Malthus' reactions to Adam Smith are discussed. Also, diminishing returns. will be considered further in Chapter V.

$$
{ }^{25} \text { Tbid., p. } 114 \text {. }
$$


Sussmilch, Price, and others, the above deductions were advanced leading to this conclusion: that, according to Malthus, his initial postulations were confirmed. Further, Malthus concluded that since the beginning of the world, the causes of population growth and decline had probably remained the same, "as constant as any of the laws of nature. ${ }^{26}$ Indeed, the fact of the persistence of passion between the sexes as remaining the same over time, and the necessary limit to population growth being availability of food supply, was natural law so obvious in its operation that Malthus thought it could not be doubted. Consequently, while it might be the case that different modes of Iimitation of population growth operated 27 (which might not be predicteole), and while the pattern of fluctuation over time in population size might also defy prediction, it was possible to say with certainty that limits to population growth were an inescapable fact. Thus, "the only true criterion of a real and permanent increase in the population of any country is the increase of the means of subsistence." 28 Because such were the conditions of population, Malthus regarded calls for encouragement of population increase to be ill-advised. He said,

$$
{ }^{26} \text { Ioid. }
$$

27 valthus considered famine to be the last check to population growth. Iike so many of the $18 \mathrm{th}$ century thinkers of France, and to a lesser degree England, Malthus saw a series of more socially conditioned limitations functioning first; namely, vice, sickly seasons, epidemics, pestilence, plague, war, plus recognition of inabilities to support families as all occurring before famine to check population growth. Ibid., pp. 118-19.

$$
{ }^{28} \text { Ibid., p. } 115 .
$$


If the tendency of marikad so tersese be so great as I have represented it to be, ft nay apes strange tinat this increase does not come when it 12 tans reason is that the demand $20=0$ popolation is made without preparing the puce ieceseny to support it. Increase the demand for agricultirel leber of pomoting cultivation, and with it consequently racreses ye produce of the country,

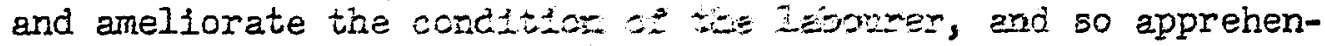
sions whatever need be extertetes lite proporional increase

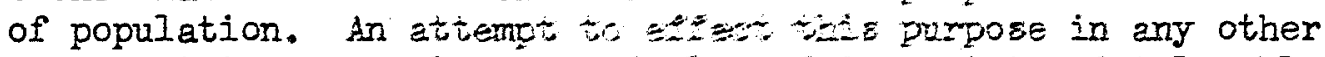
way is vicious, cruel, tyanzen, in a state of tolerable freedom cannot therefore mases. It mat appear to be the

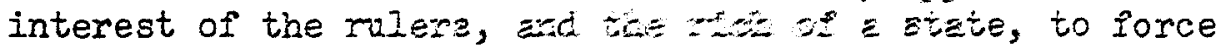
population, and thereoy lower lese lesour, and conse-

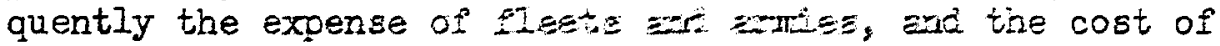

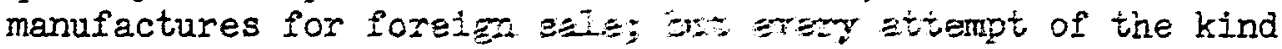
should be carefully watcher anc stumonely resisted by the

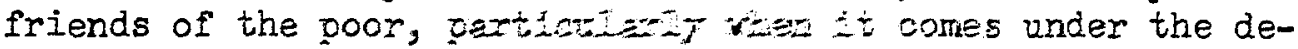
ceitful garb of benetolence, are LE Litely, on that account, to be carefully and cordein

At the close of these aranerts, Mitres adranced the conclusion that utopian beliefs in the verde wom betag a world of equality

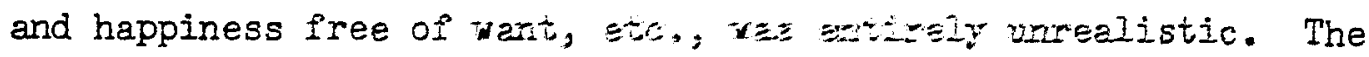
principle of population by destats yesided realization of such dreams. So also, well Lntercer eatratus besed on facts that

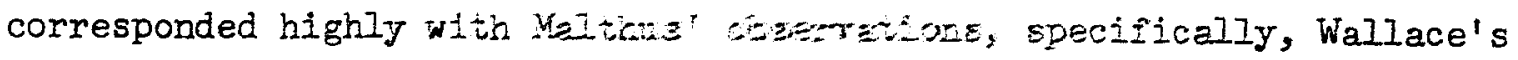

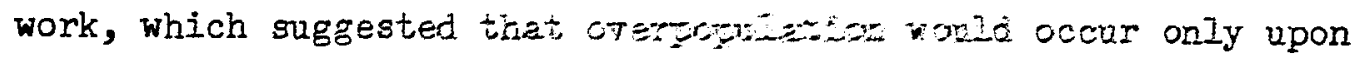

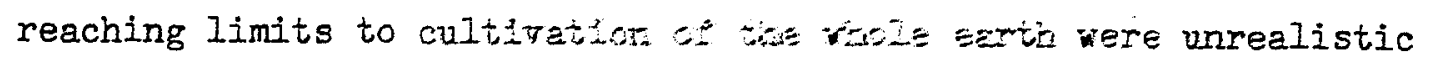
because the evidence orex tine, az zordes y diverse sources,

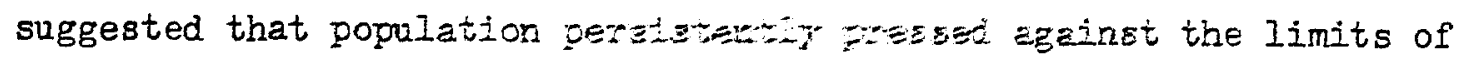
food supply. 30

At the close of these areme:to, Weltrue took pains to advance

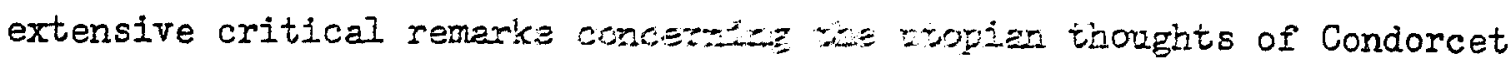

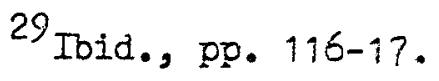

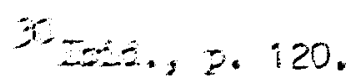


and Godwin, in which the preceding structure of arguments was brought as refutation for their views. 31

One last point of importance is found almost hidden in the concluding chapters of Malthus' essay buried in his consideration of the sources of wealth for nations. Malthus took exception to Price's, Adam Smith's and other's views on the issue. While the substance of Malthus' argument does not bear significantly upon this study ${ }^{32}$ an implied argument can be gleaned which does deal with population growth and is important to this study. Malthus advanced implicitly the argument that hopes for resolution of limits to population growth by indefinite increase in the productivity of lands were unrealistic. The highest quality soil was limited. Eventually, population increase would compel utilization of less quality soils. Thus, a diminishing returns proposition operated to close out hopes of indefinite increase in agricultural productivity; sooner or later, soils that could not produce food at all would be reached and increase in agricultural output would stop. 33

Thus Malthus concluded that the future of man did not, and could

${ }^{31}$ Further elaboration of Malthus' criticisms of Condorcet and Godwin will not be made as it is not directly pertinent to this study. The interested reader is encouraged to see The First Essay, Chs. VII$X V$.

32 Malthus' argument is not elaborated because, considering the extensiveness of the study and its goals, its length is a major problem; thus, where conservation of space can be made, it is essential. The interested student can find the argument in The First Essay, Chs. IVIXVII.

33Flew, pp. 187-91. Note Malthus never uses the term diminishing returns in his discussion, but clearly it is implied. 
not, have a utopia that was realizable. The principle of population limited man's capacity to progress.

The Second Essay

Considering the reception The First Essay received, and the diverse reactions to it, Malthus felt compelled to write a second edition. He also wrote a second edition because he wanted to modify his pessimism somewhat; he wanted to convey recognition of hope for man in the future, i.e. what could be done to ameliorate the dismal outlook for the future the vision of The First Essay portended? The second edition, in fact, turned out to be virtually a second essay for the above reasons, and because Malthus advanced more data to support his postulations. Nevertheless, the conclusions of The First Essay, except for the introduction of the principle of moral restraint, remained intact. Malthus titled the second edition, An Essgy on the Principle of Population or A view of its Past and Present Effects on Human Happiness with an Inquiry into our Prospects Respecting the Future Removal or Mitigation of the Evils which it Occasions. 34 In this work, generally, called The Second Essay, Malthus began by setting down his postulates as in The First Essay. There appears no difference between the two essays except when Malthus comes to conclude that checks on population may be separable into two ultimate types, misery or vice. In The Second Essay, a third possibility is offered: the principle of moral restraint, being "the restraint from marriage which is not followed by irregular gratifications may properly be termed moral restraint." 35

34 7 th ed., (London: Reeves and Turner, 1872). 
Beyond the introduction of the principle of moral restraint, no otiner major modifications occur. The Secand Essay provides a large body of data from which Malthus reasoned to the same conclusions as Found in The First Essay. The principle of moral restraint was apperently intended to offer "hope for the future" not found in the conciusions of The First Essay. 36

Spengler' \& Study of Malthus

Typically students of Malthus tend to focus attention on Malthus' essays on population to study his theory of population. Joseph J. Spengler concludes that such a focus does not reflect Malthus" "total popplation theory." 37 By looking at Malthus' Principles of Political

$$
35 \text { Ibid., p. } 8 \text {. }
$$

36 "Hope for the future" amounted to Malthus' belief that since man was rational, control of reproduction, hence of population growth, could be achieved inrough moral restraint. Thus, the ravages of overpopulation could be escaped. Malthus rejected artificial birth control, e.g. contraception, or such means as abortion, as he thought they led to rice.

Considering the fact that no substantial changes, beyond the introduction of the principle of moral restraint, were advanced in The Second Eseay, it would be a waste of space and time to sumarize Wathus arguments in The Second Essay.

37 Spengler makes these points concerning what he regards as this aispleced Pocus:

"Commentators on Malthus's population theory have generally based their remarks upon the Essay, particularly upon his observation that 'population invariably increases where the means of subsistence increase, unless prevented by some very poweriol and obvious checks' which are resolvable into 'moral reatraint, vice and misery.' They have overlooked important pasaages in the Essay, having to do with circumstances on wich depend the increase and the availability of subsistence, and, therefore, the growth of population. They have overlooked his extended consideration of the question of 
Economy and his correspondence with Ricardo end otsezs, Spengler found points which augmented Malthus' arguments on popuation in his essays. 38

Augmenting the general natural las of popaiejion adranced by Malthus, Spengler finds, through exanination of oteer rorks by Malthus, three main areas Malthus was also concerned wita (i) the tineory of economic progress (specifically the question of tie source and nature of the wealth of nations) and "effectual denand" 2or i jor as relates to population, (2) industrialization as a solution to the problem of economic progress and population, and (3) the relationsips of luxury, esportation of work, and population growit, ari grestions of optimum population.

Economic Progress, Labor, and Foonlation. In zic Erinciples of Political Economy, Malthus thought that "izs poogess of population in number and well-being depends upon the maintenases erd expension of the 'effective demand' for labour." 39 while MeIthas nore or less pointed

population in the Principles where his pritiey concern was the increase of the supplies on which population sowith depends. They have, therefore, missed his total porid stion theory, and the manner in which it developed. (pD. $1-2,3$

${ }^{38}$ While it may be true that Malthus aid not aticulate his total theory as Spengler does, it is not correct to $\varepsilon=y$ inet Spengler's study of Malthus amounts to a synthesis of, or change $i n$, winet Kalthus actually said. Indeed, it points out that if schoiars had made adequate study of Malthus to begin with, the joins spengler advances would have, and should have, appeared before his explication of them. Thus, it is appropriate to use Spengler as a bazis o? criticism of Marx, of comparison of Malthus to Marx, as wily be done in Chapter V. It should also be noted that Malthu did not gyetenatically advance all of his thought on population it one place. If he had, Spengler's rigorous work would have been annesdec.

${ }^{39}$ Spengler, p. 4. Note that hile MeIthe wes anicipated on this point by a number of writers, including Frerivitr, Young, and 
to the relationship between demand for labor, economic progress, and population in the various editions of his essay on population, the full articulation appeared in 1820 in the first edition of his Principles of Political Economy. In it, he said, "what is mainly necessary to a rapid increase of population, is a great and continued demand for labour. "tho Furthermore, says Spengler,

If the demand for labour is not sufficient to convert 'supplies' into consumable provisions and channel these goods to the labouring masses, the growth of the latter in number and well-being is retarded. Accordingly, assuming that subsistence is obtainable, the measure of population is the quantity of employment. For employment regulates 'the wages of labour on which the power of the lower classes of people to procure food depends; and according as the employment of the country is increasing, whether slowly or rapidly, these wages will be such as either to check or encourage early marriages; such as to enable a labourer to support only two or three, or as many as five or six children.' 41

Malthus thought the continuation of an effective demand for labor was necessary in both the short- and the long-run if population growth was to continue. Population growth appeared to fluctuate because of time-lags in adjustment to the supply of and to the demand for labor. When demand for labor sharply dropped off, population growth dropped off despite the abundance of food because marriages were less frequent when the prospect for employment was poor. 42

Steuart, and to a lesser degree Howlett and Paley, none developed as did Malthus, "the importance and pre-conditions of an 'effective demand'

$$
\begin{aligned}
& 40 \text { Tbid., p. } 7 . \\
& 41 \text { Tbid., pp. 7-8. }
\end{aligned}
$$


Malthus thought a situation might appear where a country's population fell short of its support capacity while simultaneously employment opportunities were quite robust. This condition might prevail because while the upper limits to population increase were fixed by limits of food and resources, population growth in a country depended on growth of "effectual demand" for labor. If this demand did not increase, population increase would not be stimulated regardless of availability of food and resources. Indeed, Malthus thought efforts to stimulate population increase would prove futile until an effectual demand for labor developed and wages, as a consequence, increased. 43

Now, if effective demand did indeed continue, the question arose, to what extent would population growth occur in a country? Malthus advanced the view that the extent of increase was a function of (1) habits of consumption of the population, and (2) the efficiency of use of resources of the country. Population increase would halt when (1) "the labour of a man upon the last land taken into cultivation will scarcely do more than support such a family as is necessary to maintain a stationary population," and (2) when, as a result of (1), profits drop to the lowest point necessary to maintain actual capital. 44

42 This paragraph, and this section, closely follows Spengler's argument. This writer has done this intentionaliy to insure that the reader adequately appreciates Spengler's examination of Malthus.

The reader is also reminded that Spengler is important for most of this discussion is found outside the arguments advanced in Malthus' essays on population. The importance Malthus placed on labor and demand for it as a check to population increase is generally overlooked by most studies of Malthus.

$$
{ }^{43} \text { Toid., p. } 9 .
$$


We longstendis guestive the times, namely, what is the source of the

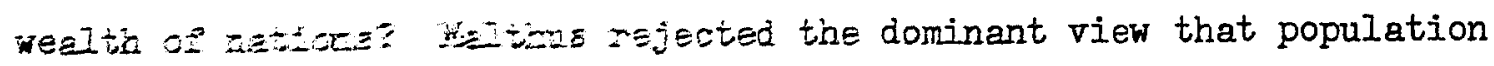

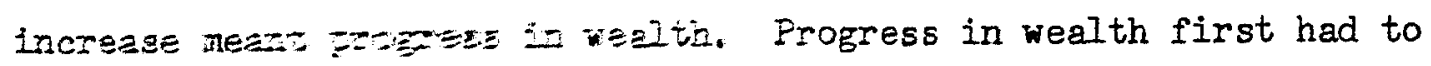
occur to gumian increase, not vice-versa. Furthermore, progress in wetre wes born merely of the hard pressure of numbers upon gubeistecos, of $2=$ rent alone. ${ }^{45}$ The desire of the laborer for goods and aertives wealih; E rectorot semead for the laborer's labor-power was also

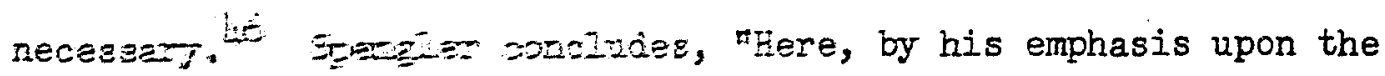

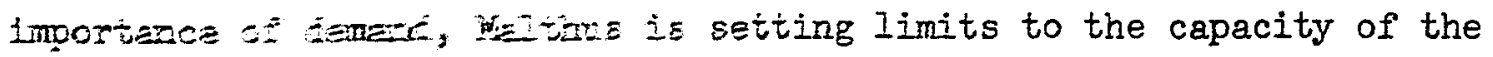
principle of protsto to generate progress, limits not so clearly

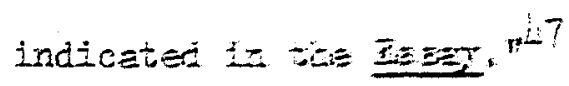

Whiz, $=\cdots$. Tre exterit of development of cultivation was limited ty to tow wages corle se prisen, pich a a function of the habits of the lower

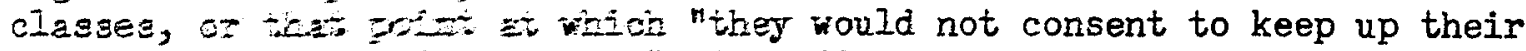
numbers to the zathes point." kccording to Spengler wages to Malthus meant mor $\equiv$ tar

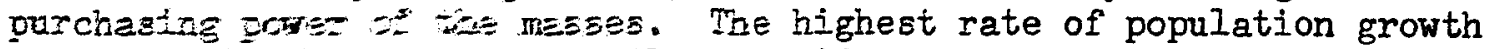

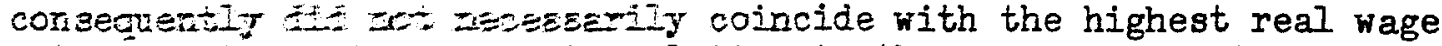
rate por wher

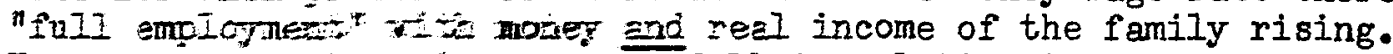
However, wher the

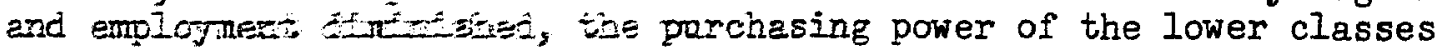

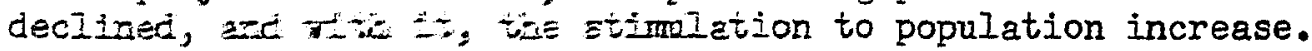

$$
45 \text { IE⿺辶., } 5 . \%
$$

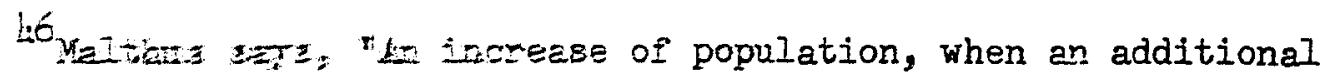

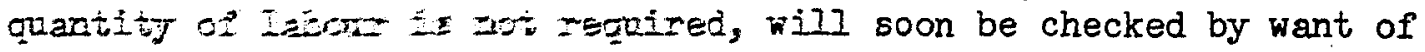
enploymext anc tes soanty suport of those employed, and will not

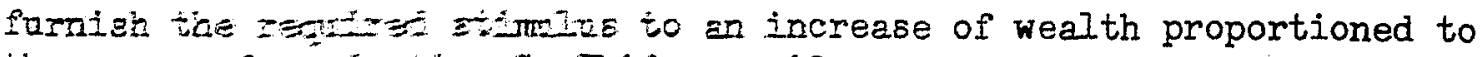

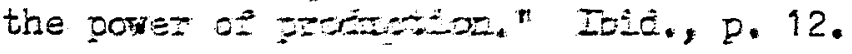

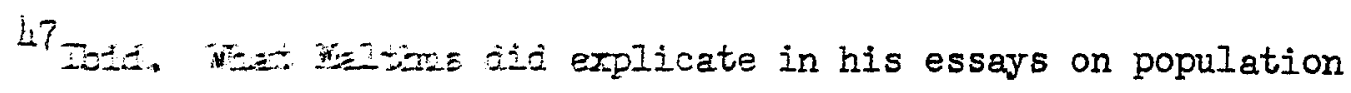


In addition to the above, the wealth of nations and popviation increase were influenced by saving, soil fertility, and imsations. Saving was regarded as a high virtue by Malthus. Its rsilation to wealth was found in its role in the creation of capital. Mitealin can be increased only through the 'conversion of revenue into capital, in thought Malthus. But saving occurred from revenue and couid angment capital, thus contribute to facilitation of growith only is it dici not diminish "effective demand" for commodities and labor, i.e. if the productive power of farmers and manufacturers grew becanze per worker output increased and one or the other decided to sete the increase, say with an eye on improving personal well-being in the suturs, the demand for labor would diminish because the manufacturer, "'oring to the parsimony of the farmers and the want of demand for manuizcivers,' would be unable to absorb the additional output of the farmer; winile the farmer, because of the inability of the mampactures to 0 , would lack a market for his added output." Thus, while saring zitt be virtuous, too parsimonious an effort would depress bota wesitr and population. 48

Malthus looked at soil fertility and its influsese ppor grouti of wealth and population. He concluded that just because a couniry might have highly fertile soil, it did not mean the country woll be

was a recognition that population increase was checked a $2 x$ ily before it so far exceeded food supply as to give rise to pamine. Trongh Spengler's study it appears in later works he clarified the revure of intermediate checks.

$$
48 \text { Ibid., pp. 12-13. }
$$


stimulated to permanently increasing its wealth. 49 Malthus' reasons for this dealt with psychological barriers to the expansion of demand and not to eventual limits to soil productivity as might be expected. Spengler says, "He emphasized, in keeping with his conception of human behavior tendencies, that the demand for income in terms of effort is such as to yield a backward falling supply for effort." 50 The taste for Iuxuries and conveniences had to be balanced against the "Iuxury of indolence" which always tended to overwhelm the luxury of goods. Thus, where revenue in a country depended on the exertion of labor, there had to be something in the commodities produced sufficiently desirable to the laborer to motivate him to work or the exertion would not be made. Indeed, thought Malthus, most men placed limits, however variable, to the quantity of conveniences and Iuxuries for which they would exert themselves. Indeed, the love of indolence operated to check progress of wealth, population, and well-being. Because of the above, Malthus placed greater emphasis on industrialization than agriculture, or soil fertility, as a means of stimulating increase of wealth because industrialization tended to expand tastes "and move the supply curve of effort downward and to the right." 51

As with soil fertility, invention of labor-saving devices, or technological progress, did not mean, necessarily, increases in wealth, population, and well-being. If the market for commodities produced was extended along with improvements in production which were "labor-

$$
\begin{aligned}
& { }^{49} \text { Tbid., p. } 15 . \\
& { }^{50} \text { Tbid., p. } 13 .
\end{aligned}
$$


saving," increase of wealth and population would not occur, but would be checked. Unless the potential for production was sufficiently united with means of distribution, wealth and population would not follow. In Malthus' view, in order to call the powers of production into full action, an "effectual and unchecked demand for all that is produced" had to be operating; and it would only happen if a sufficient distribution system plus "an adaptation of this produce to the wants of those who are to consume it," was in existence. 52 Insofar as production and distribution were, essentially, imperfectly balanced, or proportioned, where distribution could not satisfactorily circulate produce, the upper limits to increase of wealth and population would not be reached. Thus, population was actually regulated at a level well below the possible upper limits (something noted in his essays on population, but not in the detail found through augmenting the essays with additional works).

Clearly, then, Malthus found multifaceted social and economic forces operating to check growth of wealth and population as well as the natural law of population. In addition to the above, Malthus noted the importance of some political and moral elements which reinforced the checking powers of the above; namely, "security of property which depends upon the 'political constitution of a country,' upon its laws, and upon their administration," and habits of the people which make for routine behavior and "general rectitude of character." 53

Conditions which most favored the progress of wealth and

$$
52 \text { Ibid., p. } 16
$$


population involved the combination of economic, political, and moral factors and were distillable into three conditions: (1) division of landed property, (2) internal and external commerce, and (3) maintenance of an adequate proportion of society in "personal services" and situations which enabled them to demand commodities without contributing directly to their supply. Malthus considered heavy concentrations of land in a few hands ill-advised since the history of feudal times showed such arrangements to be poor producers. Only if land was adequately subdivided would an effective demand for produce and labor exist without which population and wealth could not increase. Malthus, by the time he wrote Principles of Political Economy, had come to view commerce as quite important. Through commerce, commodities were distributed throughout the population with the beneficial effect of seeing wants and the desire to consume formed. The exchange value of commodities rose, profits rose, and the desire to employ plus the ability to employ was stimulated, thus setting labor in motion. "It operates, in short, to supply that 'effectual demand,' lack of which occassions stagnation. 154 . Finally, every society had to balance consumption and production. To Malthus, society existed because more material wealth could be produced by individual workers than they could individually consume. In order to have a vital economy, the wealth had to be consumed. Thus, it was necessary to have a group, or classes, who had both the will and power to consume more than they produced. This group Malthus saw as those engaged in personal

$$
54 \text { Ibid., p. } 18 .
$$


services, like menials, soldiers, statesmen, judges, lemyera, piry icians, clergy, and teachers. Malthus stressed the importance of maintaining balance between production and consumption for either an excess of producers or of consumers would create conditions which nould not maximize employment, wealth, and (hence) population. Thus, arg but the most balanced relationship acted to check population incre-se below upper Iimits. 55

Industrialization and Population. Between the tine of The First Essay and Principles of Political Economy, Malthus' view of induetrialization changed from one where industrialization was not exienaitely considered to one where it was an instrumental factor in regulation of population growth. Malthus saw industrialization as inportant provided it was in a working balance with agriculture. In such an econom, "an adequate 'effectual demand' for labour tends to be mainteinef' and nost effective utilization of resources, provision for grow in mumer and well-being, and acquisition of habits of work and consumption concucive to propitious economic and population growth were found. 56

Spengler notes three reasons Malthus was led to ehist emphazis on industrialization. First, his considerations of the role of private property and of the views of the physiocrats and others led hin to note that the agriculturalist needed a vent for the surplus which, under a system of private property, he normally produced, and wich he would exchange for nonagricultural goods and services and for gupport of the state. 57 Second, while the growth of population depended upon increase ${ }^{55}$ Ibid., pp. 19-20. $\quad{ }^{56}$ Ibid., pp. $21-23$. 
in the food supply, the lower classes could not be considered in a good state unless some conveniences and Iuxuries were added to strict necessities for survival. However, in order to achieve such a situation the lower classes had to prevent their numbers from increasing at the same or faster pace as the means of subsistence. To accomplish this, moral restraint had to be practiced. Third, since the well-being of the lower classes depended on more than bare necessities, it was important to encourage production of conveniences and luxuries.

Malthus did not regard societies primarily emphasizing agriculture to be bad by definition, just less capable of increasing national wealth, population, and well-being. Agricultural societies had political systems and a social structure which checked population growth far below the potential for growth of wealth and population in a given country; land was inadequately divided resulting in poor production; few bases for balancing consumption and production existed; the lower classes were in the worst misery; finally the distribution system for produce was poor. Consequently, societies with industry and agriculture were more conducive to growth of wealth, population, and well-being.

There were still other reasons Malthus saw industrialization as favorable to progress in wealth, population, and well-being. First, industrialization spread the growth of habits which regulated population increase, i.e. institutionalized preventive checks, including moral restraint, which (a) protected population from increasing faster

$$
57 \text { Tbid., p. } 23 .
$$


than growth of subsistence, as was its natural tendency, and (b) protected the poor from losing economic and social advances made. 58 Second, industrialization encouraged habits of worker productivity and moral restraint because it tended to increase the price of food. Apparently, Malthus thought that if food prices were high, the prices of other commodities would have to decline to be able to fit into the remains of the laborer's wage, making the overall purchasing power of the worker's wage favorable for consumption of conveniences and luxuries, thus, in turn, reinforcing both industrial production and prudential habits. 59 Third, industrialization served to increase the relative numbers of the middle class, which in turn reduced the number of the lower classes. This resulted in recognition by the lower classes of the possibility of upward mobility, i.e. the ability to better one's condition, which served to encourage prudence since incumberment with family would foreclose the potential for upward movement.

Thus, it appears Malthus regarded industrialization as important in creating a climate conducive to growth of wealth, population, and well-being, on the one hand, and, on the other hand, important in regulating the rate at which population increased, making possible reduction in the misery of the lower classes.

Luxury, Export of Labor, Marriage and Natality, Optimum Population. Through study of all of Malthus' works, Spengler demonstrates that Malthus devoted much attention to the relationships between economic

$$
58 \text { Tbid., pp. 30-31. } \quad{ }^{59} \text { Ibid., p. } 31 .
$$


and social factors and population increase. From Spengler's meticulous study of Malthus, it appears Kalthue was concerned with additional social and economic factors affecting population; namely, (1) luxury, (2) export of labor, (3) measures which encouraged marriage and natality, and (4) optimum popalation. 60

(1) Luxury. Malthus saw trires major purposes to the production of Iuxuries: (a) they overcame indolence and stinulated, or motivated, laborers to increase productivity, (b) "they stimulated agriculture by providing a market for its producte, and helped to sustain an effective demand for labour, ${ }^{61}$ and $(c)$ they served to check too great population growth by discouraging marriege, and offering the promise of upward mobility. 62 Malthus thought the key to seeing these three purposes realized was wide distribution of a taste for and demand for Iuxuries throughout the population. Walthus thought luxury in moderation was important to increacing the realth, population, and well-being of society. Iuxury in excess could be "evil: because, in excess it restricted the increase of food supply and/or led to vice." Also, luxury, if concentrated was bad because it could only concentrate in the hands of a few at the expense of the majority; thus its ability to encourage regulation of reproduction would thereby be lost.

(2) Exportation of labor. Halthus entered the debate concerning the matter of international trade and its irmpact upon population

60 Recall from Chapter II that the above four points of issue figure heavily in the formation of and differences between many schools of thought on population preceding Kalthus in the 18th century.

$$
{ }^{61} \text { Spengler, p. } 39 . \quad 62_{\text {Ioid. }}
$$


increase which captured the attention of so many of the 18 th century. The general view of his time was that exports over imports meant high national employment and hence the basis for increases in population. This balance favoring a nation was often considered equivalent to exportation of labor. In contrast, Malthus looked at the issue from the perspective of importation of food supplies for commercial goods and warned against such action, regardless of how favorable the balance of trade. Such action he felt would make England dependent upon foreign food; productive energies would be directed to commerce instead of food. Since population increase could outrun food increases, since food supply needed to be secure to maintain the well-being of the population, Malthus rejected the wisdom of depending on foreign food. Spengler says of Malthus' reasoning, "a nation, particularly if it was large, could not safely and judiciously exchange labour embodied in commerce and manufactures for foreign-produced foodstuffs, and thus support part of its population at the expense of foreign-owned food funds," because it was uncertain that a country could continually export an ever expanding volume of manufactures, "receiving in exchange a correspondingly expanding volume of food and raw materials, and so support a continually expanding population" at a persistent level of living consistent with national expectations. ${ }^{63}$ Several reasons operated to make difficult the procurement of subsistence by a country which had shifted to emphasis on production of commercial goods for export: (1) competition from other countries in the markets of the ${ }^{63}$ Ibid., p. 42. 
world might undercut the security of trade relations between countries, (2) food-supplying countries might eventually develop their own manufactures, with the result being erasure of the need for or basis of the trade relation, (3) foreign markets may be saturated, and (4) the country providing food and raw materials might not have an expanding market to absorb expanding commercial goods. As a result, importing countries face potential problems which feed back to impair the countinued progress of wealth, population, and well-being if the countries relied on foreign trade. Therefore, Malthus thought a selfsufficient system of agriculture and commerce furnished the best basis for progress in wealth, population, and well-being. 64

(3) Pro-marriage and pro-natality measures. Malthus rejected as unwise and unnecessary the social, economic, and political efforts to encourage early marriage and increased births. If the country wanted to increase its population, the food supply necessarily had to expand, and wealth had to be increased. If this occurred, increases in population would follow. Measures which attempted to encourage marriage and births were based upon inadequate and false knowledge of the principles of population. Malthus, however, did approve of changes in economic structure which served to increase the effective demand for labor since doing so facilitated population growth. He also encouraged improvement in the distribution system for food and commodities because it would increase wealth, hence population, and well-being. 65

${ }^{64}$ Ibid., pp. 42-43. Note that in today's world, the PRC calls such self-sufficiency "self-reliance" and more or less explicitly embraces Malthus' views on the merits of such a stance. The USSR does not consider either self-sufficiency or self-reltance in its views. 
(4) Optirnum population. Malthus' considerations of optimum popolation appear implied but not explicitly stated. He viewed population growth as advantageous only when it contributed to the happiness of society, thus population increases should stop if they do not contribute to the happiness of society.

It can be seen from Spengler's reconsideration of Malthus that there was far more dimension to the structure of Malthus' preventive checks to population growth than appeared from merely reading his eseays on population. Also, thanks to Spengler, it appears Malthus' study of population was more extensively an economic study than it appeared from just reading his essays on population.

\section{MALTHUS AND THE DEVELOPMENT OF DEMOGRAPHY}

Having considered the historical time period in which Malthus wrote and wat he actually said on the subject of population, following on the heels of a discussion of a century of multiple schools of population thought, the question arises, why was Malthus so important? or put another way, what did Malthus do for demography?

While it is true that Malthus said nothing original, i.e. said nothing that had not been said by many others in the 18th century, he did gain greater attention than others before him and did advance a position which used preceding information to synthesize a position of his own. Looked at in toto, his view was novel because it made population the central focus of inquiries into social problems. And after halthus, (1) social sciences had to deal with population 
questions when considering social problems and (2) a new field of study devoted predominantly to purely demographic questions was given a strong push toward firmly establishing itself because of Malthus' causing such a stir. In other words, Malthus' importance comes from institutionalization of population issues in social studies and of the science of demography which followed (and was no doubt stimulated by) Malthus' work. Malthus helped normalize demographic study by specifying key issues needing study, namely, (1) what factors determined the rate of increase and hence the development of human populations? and (2) what were the consequences of these factors and of the numbers that increased? ${ }^{66}$ In addition to helping normalize the questions demography asked, Malthus' utilization of the quantitative tools of Graunt, Petty, Sussmilch and others helped reinforce future developments of demography on a quantitative footing. Finally, because he helped normalize the structure of demographic inquiry, Malthus became the basis for much demographic "self-analysis," i.e. much of the advance proceding Malthus came by looking critically at the many shortcomings in the method of inquiry and key issues Malthus specified.

Davis' critical look at Malthus admirably summarizes the major critical problems with Malthus which invited and required further studies by population students proceding Malthus. Davis says, "Malthus' theories are not now and never were empirically valid, but they

66 Kingsley Davis, "Malthus and the Theory of Population," in Paul I. Lazarsfeld and Morris Rosenberg, The Language of Social Research, (Glencoe: The Free Press, 1955), p. 543. 
nevertheless were theoretically significant and, as a consequence, they hold a secure place in intellectual history." 67

Davis distinguishes theory from scientific theory; the latter being a developed systematic body of abstract and empirically tested theory; theory involving four key elements, (1) a frame of reference, (2) a set of deductive propositions, (3) a set of empirical propositions verified by disciplined observation, and (4) crude empirical propositions based only on commonsense observations. ${ }^{68}$ Critical problems with Malthus, Davis says, are found by looking at Malthus with the above four elements to determine the theoretical or scientific theoretical veracity of Malthus' population thought.

(1) Frame of reference. Davis views two main functions to a frame of reference for theory; (a) to provide systematic criterion of relevance, and (b) to provide a set of interrelated categories in terms of which an empirical system is to be described thus providing $a$ test of descriptive adequacy. 69 Davis looks at what Malthus asserted his purpose to be, i.e. to inquire into the relation of population increase and the happiness of mankind. Davis concludes that Malthus entangles a moralistic view of what ought to be with a scientific inquiry into what actually exists. Davis says Malthus' frame of reference "mixes moralistic and scientific aims almost inextricably, "70 Further, the postulation that the passion between the sexes is necessary and will remain nearly in its present state implies the

$$
\begin{array}{ll}
{ }^{67} \text { Ibid., p. } 541 . & { }^{69} \text { Ibid. } \\
{ }^{68} \text { Tbid., p. } 542 . & 70 \text { Ibid., p. } 543 .
\end{array}
$$


operation of instinct. Furthermore, the mechanisms of reproduction are not articulated. Hence, Malthus overlooks implications that affect checks to population growth. Also, his key terms, i.e. moral restraint, vice, and misery, are subject to cultural relativism resulting in subjective instead of objective definitions of principal notions, itself another manifestation of confusion of moral and scientific reasoning. Finally, the term "means of subsistence" is loosely defined resulting in uncertainty of meaning, hence of frame of reference. 71

(2) Malthus' theory as a deductive system. Davis notes that modern demographers have at their disposal a series of highly refined mathematical and statistical tools which provide the basis for propositions of pure theory; i.e. propositions universally applicable because they are logically deduced from assumptions. Many of the modern demographer's most useful analytical tools are born of pure theory and "hardly dreamed of in Malthus' day."72 A chief weakness in Malthus rests in his failure to "clearly distinguish between propositions of pure theory and those of empirical reference. Not only did he jump at once into deductive propositions without much logical analysis behind him, but he sometimes assumed these to be. descriptive of nature." 73 Davis scrutinizes propositions advanced by Malthus, e.g. man's capacity to reproduce is greater than his capacity to increase the means of subsistence, and concludes that it is unclear whether his propositions were intended as axioms or merely

$$
\begin{aligned}
& { }^{71} \text { Ibid., pp. } 543-46 . \\
& { }^{72} \text { Tbid., p. } 547 .
\end{aligned}
$$


as descriptions of readily observable natural processes. Thus, their logical status is unclear. Hence, problems occur when reasoning from unclear propositions. Also, meanings of terms are imprecisely stated and empirical questions are interspersed in his deductive system. The result is a deductive system that is confused, indeed muddled. As such, its value for advancing scientific theory is quite limited. 74

(3) and (4) Enpirical propositions and elemental generalizations. With refinement of the elemental into the scientific as a goal of scientific inquiry, empirically testable propositions are desirable; and the atiempt to refine elemental propositions into scientific ones is the goal. In looking at Malthus, Davis finds his empirical propositions not supported with experimental evidence because statistics were not good in his time and Malthus' theoretical structure was not rigorous enough to make testing possible. 75 Davis says Malthus relies too heavily upon neither verifiable nor disprovable anecdotal information. \&s a result, his structure of crude generalizations regarding the relation of population growth to means of subsistence, and to intermediate factors which play a modifying role in checking growth before upper limits are reached, e.g. that marriages are postponed because of economic difficulties securing a livelihood for the family, are stated ambiguously, in a conceptual framework that confuses moralism and science, and with empirical data that largely neither proves or disproves his propositions. Consequently, Malthus' propositions come up short; indeed, his theoretical position as a

$$
74 \text { Ioid., pp. 547-48: } \quad 75 \text { Ibid., p. } 549 .
$$


whole comes up short not because it is fallacious, but because it is not very scientific and cannot be supported or rejected on the basis of its arguments.

With such faults as the above in his theory (but given his historical importance), it should not be surprising that Malthus produced a watershed of further research into population questions. Indeed, in addition to Malthus' shortcomings being an important stimulation to further study, Malthus was an important transition point for the development of demography beceuse after Malthus, social scientists could not study social problems without taking population into account, and population studies per se gained stature as an important field of study. 
CHAPTER IV

$$
\operatorname{MARX}^{1}
$$

It may be true that Malthus had a profound impact on both social science studies of social problems and in contributing to the institutionalization and normalization of a science of demography. However, it would be inappropriate to draw the possibly implied conclusion following from preceding pages of this study that only criticism focused around resolving ambiguity and articulating population theory in greater detail arose in reaction to Malthus. In fact, strong opposition to Malthus

1Karl Marx (1818-1883). Biographical notes on Marx cannot as easily be made as with Malthus. Marx's life and his times were much more complicated than Malthus' life and times. The motivations stimulating Marx's discussion of population are not as clear as with Malthus. The historical context in which Marx wrote was turbulent; the 19th century saw vast industrial development, scientific and technological transformations, and political revolutions. Socialism developed into a popular and powerful philosophy. The social progress of the times was so great that limits to its continuation were not considered; views seeing progress as indefinitely extensible and $\operatorname{man}$ as invincible, i.e. capable of resolving problems and overcoming obstacles in the way of future progress, gained powerful support. In this world, Marx's views of the nature of man, society, and hence population were formed. Mars was a revolutionary thinker; no doubt some of his criticism of Malthus was born of his anti-bourgeois stance. Also much of his criticism was born of belief in the view of man as invincible; hence a rejection of Malthus who considered man's progress to be limited.

For a remarkable biography of Marx see Franz Mehring, Karl Marx, the Story of His Life, (Ann Arbor: The University of Michigan Press,

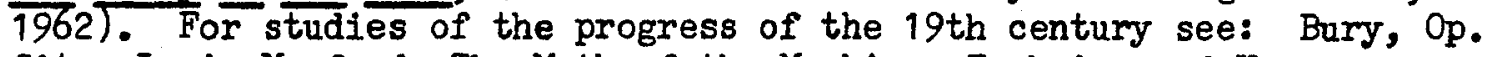
Cit.; Lewis Mumford, The Myth of the Machine: Technics and Human

Development, (New York: Harcourt, Brace, Jovanovich, Inc., 1967) and The Myth of the Machine: The Pentagon of Power, (New York: Harcourt, Brace, Jovanovich, Inc., 1970); Harry W. Laidler, History of Socialism, (New York: Thomas Y. Crowell Company, 1968); and Samuel Lililey, Men, Machines and History, (New York: International Publishers, 1966). 
arose. Some denied that Malthus correctly pinpointed key issues, e.g. that there was a natural law of population growth, or that the social problem of poverty was a function of this natural law. Some denied that the principle of population correctly described reality. Finally, some considered the structure of Malthus' reasoning little more than counter-revolutionary rationalization of the status quo. A look at 19 th century thought finds these arguments advanced by many. In Karl Marx, they are all combined; Malthus is criticized and his theory is criticized; an articulation of a different view of population is offered.

Marx's discussion of population is concentrated in Capital, Vol. I; mostly found in his advancement of the law of capitalist accumalation. ${ }^{2}$ Now Marx's discussion of pupulation is not advanced as a theory of population per se; instead it is an integral part of a larger theoretical economic argument. In fact, the discussion of population

${ }^{2}$ Karl Marx, Capital, I, (New York: International Publishers, 1967). This volume of Capital was first published in 1867.

Note that Marx's views on population were first developed by Engels as early as 1844 . They were transferred to Capital virtually without alteration. They became more thoroughly integrated into Marx's sophisticated socio-economic theory in Capital, it is true, but they did not become significantly altered from Engels' original statements to permit the ideas to be attributed entirely to Marx.

In his introduction to Capital, Engels cites his role as quite subordinate to Marx. This writer thinks Engels was far too modest; that in fact Engels was Marx's equal. Perhaps, even, Engels was a greater economic thinker than Marx while Marx was the superior philosopher. The only appropriate way to view them is as integrated thinkers. While Engel' name will not be mentioned mach in this chapter, this writer means to imply his presence when referring to Marx.

Engels' early statements are in Outline of a Critique of Political Economy (1844) and The Condition of the Working Class in England in 1844 (1845). This writer drew information from Meek, op.Cit., pp. 56-63, \& 75-81. 
suddenly pops out of his discussion of capitalistic accumulation. In order to fully appreciate Marx's view, it will be necessary to assemble a substantial background into Marx's reasoning, his theoretic system in general, and the thrust of his general argument in capital. ${ }^{3}$ Also, this background will enhance appreciation of the often subtle differences between Marx and Malthus which will be explicated in Chapter V. So, while the central purpose of this chapter is to present Marx's thought on population, the chapter will begin with an introduction to Marx's reasoning system, including description of dialectical materialism, historical materialism, his world-view on the nature of social order, and some key notions used in his treatise on capitalism; afterwhich will follow initial aspects of Marx's reasoning in Capital which leads into full discussion of population; and finally, the elaboration of the Law of Capitalist Accumulation in which is found both Marx's thought on population and his criticisms of Malthus and Malthus' population theory will be made. The chapter will close with a brief summary.

3 Veblen makes the important point that if Marx's thought is not viewed as a whole, "the Marxian system is not only not tenable, but it is not even intelligible." Thorstein Veblen, "The Socialist Economics of Karl Marx and his Followers," in his the Place of Science in Moderm Civilization and Other Essays, (New York: Russell and Russel1, 1961), p. 410. This writer agrees with Veblen but finds a full-scale outline of the whole of the Marxian system unnecessary to accomplish the purpose of this chapter. Consequently, this writer will rely upon Veblen's excellent summary of Marx to provide the necessary information and encourages the reader to pursue further detail by reading original works by Marx and Engels appearing in footnotes to follow. 


\section{MARX'S REASONING SYSTEM}

Marx's reasoning system has two principal components; (1)

dialectical materialism and (2) historical materialism. Dialectical

materialism is both a system of analysis and part of a more comprehensive reasoning system. By adding historical materialism, derived from dialectical materialism, the heart of the reasonsing system is found. 4 After presenting dialectical materialism and historical materialism, a look at some assumptions underpinning the system will serve to enhance appreciation of Marx.

The dialectical materialist method of analysis is a three-phase dialectical system Marx says he gained from Hegel. In the hands of

${ }^{4} \mathrm{Veblen}$ notes that there is no system of economic theory more logical than that of Marx. "No member of the system, no single article or doctrine, is fairly to be understood, criticised, or defended, except as an articulate member of the whole and in the light of the preconceptions and postulates which afford the point of departure and the controlling norm of the whole." (Veblen, pp. 410-11.) This is a critical point to note because Marx behaves as both the master of his logic and its slave. Marx must follow his logic and presume population processes as he articulates them to maintain logical consistency. He admits he must attack Malthus as he does, because if Malthus is correct, he says, "I can not abolish the law ('the iron law of wages') even if I abolish wage labor a hundred times over, because the law then governs not only the system of wage labor but every social system." Marx then goes on to say, "Basing themselves directly on this, the economists have proved for fifty years and more that socialism cannot abolish poverty, which has its basis in nature, but can only generalize it, distribute it simultaneously over the whole surface of society!" (From Marx's Critique of the Gotha Programme, published in 1875; quoted from Meek, pp. 117-18. T Marx recognizes his enslavement to his Iogic, and the consequences of his being wrong. This point turns out to be $a$ crucial criticism which will be considered again in Chapter $V$.

5 Hegel's dialectical system is found in Science of Logic, 2 vols., (New York: Humanities Press, 1966) and to a lesser degree in Phenomenology of Mind, (New York: Harper Torchbooks, 1967). Gustar E. Mheller, in his "The Hegel Legend of 'Thesis-Antithesis- 
Marx and Engels this system conceptualizes movement as universal and necessary, as transformational, and as resting upon inevitable conflict, or struggle. In fact, struggle is the basis from which movement occurs

Synthesis'" in Journal of the History of Ideas, XIX, No. 3, (June 1958), 411-13, says that scholars have been inappropriately led to believe that Hegel formulated his thinking on the basis of the dialectical trinity; thesis, antithesis, synthesis. He says that this attribute of Hegel's thinking is strictly an imputed dimension, that Hegel himself opposed this framework. Quoting Mueller:

"The actual texts of Hegel not only occasionally deviate from 'thesis, antithesis, synthesis,' but show nothing of the sort. 'Dialectic' does not for Hegel mean 'thesis, antithesis, synthesis.' Dialectic means that any 'ism'-which has a polar opposite, or is a special viewpoint leaving 'the rest' to itself-must be criticized by the logic of philosophical thought, whose problem is reality as such, the 'world-itself.'

"Herman Glockner's reliable Hegel Lexikon (4 volumes, Stuttgart, 1935) does not list the Fictean terms 'thesis, antithesis, synthesis' together. In all the twenty volumes of Hegel's 'complete works' he does not use this 'triad' once; nor does it occur in the eight volumes of Hegel texts, published for the first time in the twentieth century. He refers to 'thesis, antithesis, and synthesis' in the Preface of the Phaenomenology of Mind, where he considers the possibility of this 'triplicity' as a method or logic of philosophy. According to the Hegel-legend one would expect Hegel to recommend this 'triplicity.' But, after saying that it was derived from Kant, he calls it a 'Iifeless schema,' 'mere shadow' and concludes: 'The trick of wisdom of that sort is as quickly acquired as it is easy to practice. Its repetition, when once it is familiar, becomes as boring as the repetition of any bit of sleight-of-hand once we see through it. The instrument for producing this monotonous formalism is no more difficult to handle than the palette of a painter, on which lie only two colours....' (Preface, Werke, II, 48-49)."

Mueller goes on to note that Hegel's work History of Philosophy, finds Hegel mentioning in the Kant chapter the "spiritless scheme of the triplicity of thesis, antithesis, and synthesis." Hegel makes this reference in connection with references about the rhythm and movement of philosophic knowledge being artificially prescribed.

Mueller suggests that it would be no mean trick for Hegel to suggest this focal concept, $i . e$. the dialectical triad, in a hidden form. Mueller then goes on to list the names of many contemporary thinkers that have abandoned the "legend." Mueller lists Theodor Litt, and Emrich Coreth, Theodor Haering, Iwan Iljin, Hermann Glockner, and 
and transformation arises. Finally, dialectical materialism frames

movement as a linear progression derived from the necessary repetition

of the same cyclical process which results in a necessary staged

movement always from lower to higher states of order. 6

Theodor Steinbuchel as those essentially coming to a view similar to his own. Quoting Mueller again:

"In an essay by Nicolai Hartmann on Aristoteles und Hegel, I find the following additional confirmation of all the other witnesses to the misinterpretation of Hegel's dialectic: 'It is a basically perverse opinion (grundverkehrte Ansicht) which sees the essence of dialectic in the triad of thesis, antithesis, and synthesis.' The legend was spread by Karl Marx whose interpretation of Hegel is distorted. It is Marxism superimposed on Hegel. Thesis, antithesis, synthesis, Marx says in Des Elend der Philosophie, is Hegel's purely logical formula for the movement of pure reason, and the whole system is engendered by this dialectical movement of thesis, antithesis, synthesis of all categories. This pure reason, he continues, is Mr. Hegel's own reason, and history becomes the history of his own philosophy, whereas in reality, thesis, antithesis, synthesis are the categories of economic movements. (Sumary of Chapter II, paragraph 1.)"

It can be seen from the above that questions regarding the character of analyses made of Hegel's thought must be raised. If Meller is correct many scholarly considerations of Hegel must be reconsidered; not the least of them being Marx.

6 Engels specifies three laws of movement as forming the base of dialectical materialism; (1) "the law of the transformation of quantity into quality and vice versa;" (2) "the law of the interpenetration of opposites;" (3) "the law of the negation of the negation;" he notes that the laws were derived from Hegel's laws of thought, the first found in the first part of Hegel's Science of Logic, the second filling the whole of the second part of his Logic, the Doctrine of Essence, and the third figuring as the fundamental law for the construction of the whole system. Engels says Marx and he amended Hegel by deducing Hegel's laws from nature and history instead of making Hegel's mistake of presuming the laws to be laws of thought which were foisted upon nature and history. Frederick Engels, Dialectics of Nature, (New York: International Publishers, 1940), pp. 26-27. Further discussion of dialectical processes can be found in Engels' Herr Eugen Dahring's Revolution in Science (Anti-Dühring), (New York: International Publishers, 1939). 
Historical materialism ${ }^{7}$ is a framework which applies the dialectical materialist framework to the analysis of social change. Historical materialism is stated in a condensed form in the Preface of A Contribution to the Critique of Political Economy, written by Marx in 1859.8 In this statement Marx sets down his view of society as a

7 Veblen appropriately notes that historical materialism is essentially Hegelian in nature, though derived from the Hegelian Ieft via Feuerbach. Veblen, p. 413.

${ }^{8}$ Considering the importance, and brevity, of the relevant portion of Marx's Preface in which the historical materialist framework of social change is explicated, it is here quoted.

"In the social production which men carry on they enter into definite relations that are indispensable and independent of their will; these relations of production correspond to a definite stage of development of their material powers of production. The totality of these relations of production constitutes the economic structure of society-the real foundation, on which legal and political superstructures arise and to which definite forms of social consciousness correspond. The mode of production of material life determines the general character of the social, political and spiritual processes of life. It is not the consciousness of men that determines their being, but, on the contrary, their social being determines their consciousness. At a certain stage of their development, the material forces of production in society come in conflict with the existing relations of production, or-what is but a legal expression for the same thing-with the property relations within which they had been at work before. From forms of development of the forces of production these relations turn into their fetters. Then occurs a period of social revolution. With the change of the economic foundation the entire immense superstructure is more or less rapidly transformed. In considering such transformations the distinction should always be made between the material transformations of the economic conditions of production which can be determined with the precision of natural science, and the legal, political, religious, aesthetic or philosophical-in short ideological, forms in which men become conscious of this conflict and fight it out. Just as our opinion of an individual is not based on what he thinks of himself, so can we not judge of such a period of transformation by its own consciousness; on the contrary, this consciousness mast rather be explained from the contradictions 
socio-economic class struggle, rooting the nature of society in the means of production, with social and economic relations, and the cultural life of society, derived therefrom. Dialectical materialism is especially evident in Marx's view of struggle (or social conflict) as essential and transformation (social change) occurring from struggle. In the nature of the system is found its own self-destruction, or negation, where occurrence of change is self-conditioning, self-acting, and unfolding of inner necessity.

Enhanced appreciation of Marx can be gained from noting some assumptions he makes, explicitly and implicitly, which support his reasoning system. Veblen notes that Marx's later training made him an expert in the system of Natural Rights and Natural Liberty. ${ }^{9}$ Veblen

of material life, from the existing conflict between the social forces of production and the relations of production. No social order ever disappears before all the productive forces for which there is room in it have been developed; and new, higher relations of production never appear before the material conditions of their existence have matured in the womb of the old society. Therefore, mankind always sets itself only such problems as it can solve; since, on closer examination, it will always be found that the problem itself arises only when the material conditions necessary for its solution already exist or are at least in the process of formation. In broad outline we can designate the Asiatic, the ancient, the feudal, and the modern bourgeois modes of production as progressive epochs in the economic formation of society. The bourgeois relations of production are the last antagonistic form of the social process of production; not in the sense of individual antagonisms, but of conflict arising from conditions surrounding the life of individuals in society. At the same time the productive forces developing in the womb of bourgeois society create the material conditions for the solution of that antagonism. With this formation, therefore, the prehistory of human society comes to an end."

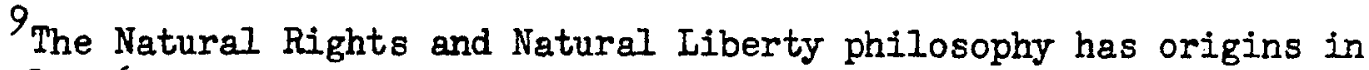
the early 16th century rise of mercantilism. The position was firmly 
says Marx included this system in his thought and held the canons of this school inviolate. 10 However, Marx's use of the concepts was not bourgeois; he utilized them in conjunction with Hegelian and materialist concepts previously noted. The result was a synthesis of ideas which brought, in Veblen's view, a "progressive and humanistic" perspective to Marx. 11

established as an ideologically significant thmist with John Locke. Several strains could be identified as emanating from Locke. One of them was the contract theory tradition of Rousseau in France, Jefferson in America, and Paine in England. Another strain which was critical of the contract theory stems from David Hume. See Becker and Barnes, Op. Cit., Ch. 10. See also footnote 11 of this chapter.

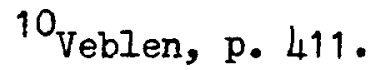

${ }^{11}$ Hume criticized the social contract theory of Locke. He described the chief advantage of society to be mutual aid which comes through association. He rejected the view that governments were founded on contracts and argued that the social cement binding men together under a particular governmental form was force exerted through usurpation or conquest. Force was also the basis for a change in governments, not contracts.

Hume al so rejected the contract theory's assumptions that a presocial state of nature for man could exist. Hume said from the outset man must be viewed as social. The basis of society from the outset was social; being the family; which impelled man to seek society by necessity, inclination, and habit. Habit made obedience a matter of course, thus providing a basis for the building of government. Government probably emerged out of a trial and error process, most probably through warfare. Through mixture of force and conscent, imperfect beginnings matured into a state of government with authority.

What is pertinent for this study is, first, that Hume's work saw man as always a social animal; second, that his theory of government implied man rising out of nature from a social base; third, that Hume's work was regarded as a forerunner of utilitarianism. His emphasis, over all else, was that society formed from mutual aid that naturally derives from association.

Marx was aware of Hume's work. Marx's views on the above points do not substantially differ from Hume; some of Marx's base assumptions appear born of Hume. These background points are important to keep in mind because the assumptions which follow are important elements in a later explanation of why Marx reacted to Malthus as he did. Also, seeing these origins helps to appreciate why Marx saw population 
The argument that derives from the synthetic combining of the a.ove strains goes as follows. Two factors make man different from other animals, (1) production and (2) history. The latter manifests itself asing the former as its basis. Marx writes:

Kan can be distinguished from animals by consciousness, by religion, or by anything one likes. They themselves begin to distinguish themselves from animals as soon as they begin to produce their means of subsistence, a step which is determined by their physical constitution. In producing their means of subsistence men indirectly produce their actual material life.12

Engels distinguished man from other animals thusly: animals collect means of subsistence from what is available, man produces means of subsistence from what materials are at his disposal. This places man in a creative role in his relationship with nature. Indeed, Engels concludes that through production nature becomes dependent upon man. 13

processes 88 he did, and from where, philosophically, the differences between Kark and Malthus emanated.

For a discussion of Hume, see Becker and Barnes, pp. 396-403. The orerlap between Marx's and Hume's views can be seen by reading Marx's estimations of the origin of the division of labor. See Capital, I, Ch. IIV.

12 Excerpt from German Ideology in T.B. Bottomore, Karl Marx: Selscted Writings in Sociology and Social Philosophy, (New York: WeGraw-Hill Book Company, 1964), p. 53.

i3 Engel8, Dialectics of Nature, pp. 209-10. Note: In his early works Harx said, "Animals produce only for themselves, while man reproduces the whole of nature. The products of animal production belong directly to their physical bodies, while man is free in face of his product." T.B. Bottomore, Karl Marx: Early Writings, (New York: McGraw-HiII Book Company, 1964), pp. 127-28.

This view of man cannot withstand the test of validity the whole problem of limits to growth now facing industrial society presents. In Pact, it is an obsolete view in today's and for tomorrow's world. For a strong critical argument see Eugene S. Schwartz, Overskill: The Decline of Technology in Modern Civilization, (New York: Quadrangle Books, 1971). 
Nature's dependence on man derives from man shifting into a relatively independent role vis-a-vis nature because he produces. Instead of being shaped by the brute forces of nature, man comes to play a creative role capable of shaping nature. Through production, man's direct relationship to nature becomes indirect. Thus, through production, man creates his own world, and eventually comes to dominate.

Marx goes even further in his last work, Capital, Vol. III, concluding that socialized man, and production, can rationally regulate the interchange between man and nature, can bring nature under common control, and thereby eliminate rule by blind forces of nature. 14

If production serves to remove man from dominance by nature, what part does history play in making man different from other animals? Under the force of dialectical materialism and historical materialism, production must develop transformationally moving always to higher stages. Because production sets human society apart from the brute forces of nature, development of society has its own history. In fact, the making of history serves to set man even further apart from nature. On this point Marx wrote that at each stage of history there is found a material result, "a sum of productive forces;"

a historically created relation of individuals to Nature and to one another, which is handed down to each generation from its predecessors, a mass of productive forces, capital, and circumstances, which is indeed modified by the new generation but which also prescribes for its conditions of life and gives it a definite development, a special character. 15

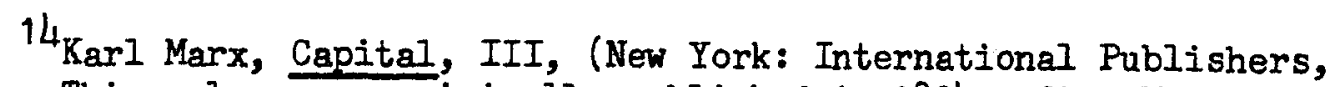
1967). This volume was originally published in 1894, after Marx's death. 
To summarize some important assumptions Marx makes which bear upon enhancing appreciation of his thought on population, the following Iist is offered. Explicitly, Marx assumes:

1. Social man is moving in a progressive manner toward an ultimate goal of perfectibility. 16

2. Production is indefinitely extensible. 17

3. Man, through production and history (and reason is implied as important also) can control nature, and is therefore not subject, in toto, to natural laws; indeed, as production develops, subjection to natural laws decreases. 18

4. The individual's standard of living can be always extended.

${ }^{15}$ Bottomore, Selected Writings, p. 55.

16 Examination of Marx's footnotes and bibliography in Capital shows a thorough awareness of the philosophical and economic (and population) thought of the 18th century. The philosophies of progress of the 18th century helped form the foundation principles of the French and American Revolutions. Marx's revolutionary position, scientific socialism, also has rootes in these philosophies. Hence, it is this writer's conclusion that Marx posited a position of perfection for man though this writer has not found a direct expression of this view (although often Marx's statements approach it). This writer chose to consider this an explicit assumption because it is so clearly evident in the general perspective Marx takes on development of human society. Also, to reinforce this point, see Karl Marx and Frederick Engels, "Manifesto of the Communist Party," Selected Works, Eng. ed., (Moscow, 1951), I, pp. 32-61. Also, V.I. Lenin, The State and Revolution, (Peking: Foreign Languages Press, 1970). Discussion of philosophies of progress in Bury, Op.Cit., and Becker and Barnes, Ch. XII.

17 In a letter to Lange 29 March 1865, Engels makes it clear that production itself is not limited; i.e. under proper conditions production could increase indefinitely; but production was limited because opportunistic capitalists seeking to increase profits controlled growth. See Meek, pp. 85-87.

${ }^{18}$ Marx, Capital, I, Ch. VIII, especially p. 177. 


\section{Implicitly, Marx assumes:}

1. The important focus is on looking for social change unfolding from inner necessity.

2. Indeed, looking into the nature of social change, therefore, requires looking into internal conditions, actually contradictions, of social processes.

3. Such assumptions consider external relations of society, i.e. man-nature relations, as insignificant, hence unnecessary to look at. Man need only look to himself to explain all social processes; and all processes affecting man are social. 19

Considering the combined background of dialectical materialism, historical materialism, and explicit and implicit assumptions made by Marx, his world view on the nature of social order, not surprisingly, takes the form of emphasis on struggle; specifically, class struggle. Veblen says to Marx, the nature of class struggle is not expressed in terms of a strictly material referent, e.g. as phsiological or mechanical material, but in a metaphorical sense as economic material which manifests itself as struggle between classes for the means of subsistence. 20 With this perspective, the social order takes its form

${ }^{19}$ This disregard for man-nature relations as significant in studying social change ranks as one of the essential differences between Marx and Malthus (who considered nature to perpetually, and inexorably, dominate man through the natural law of population). At base, the essential disagreement stems from the different philosophical

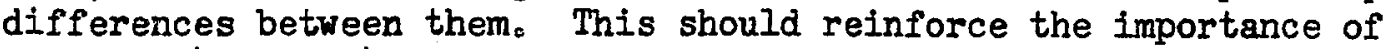
footnote 4, p. 104 of this chapter where it was noted that the nature of Marx's reasoning system compelled him to challenge Malthus in order to maintain the viability of his system.

${ }^{20}$ Veblen, pp. 413-15. Note: This view has subtleties that requires awareness of assumptions Mari made and implied to be better 
through class struggle. The character of the struggle is determined by the prevailing mode of production and exchange in force. The dialectical movement of social progress moves, therefore, in Veblen's words, "on the spiritual plane of human desire and passion, not on the (literally) material plane of mechanical and physiological stress on which the developmental process of brute creation unfolds itself." 21 Veblen concludes his point by saying Marx's materialism is "a sublimated

appreciated. Recall that Marx thought the appropriate focus of attention rested on social relations and not ones between man and nature. (While this is somewhat ahead of the story...) Add the assertion Engels makes in a letter to Lange, 29 March 1865 that "... the pressure of population 18 not upon the means of subsistence but upon the means of employment...." (Meek, p. 86) Combine the two points and a question arises of great import: does Marx mean class struggle is manifest between classes struggling for the means of subsistence or for the means of employment? This writer thinks the following explanation might be offered using Marxian logic:

Means of subsistence for socialized man are produced. Production is an organized system of ways and means, or forces or modes, of producing. Recall, production lifts man outside brute forces of nature; so the means of subsistence derived from forces of production become internal factors significantly contributing to the form of social order. In the capitalist mode of production, means of subsistence are subject to control through ownership; ownership becomes $a$ principal basis of class delineation. Classes separate, on this basis, into nonowners and workers who sell their labor-power to earn money used to buy subsistence versus owners who "own the subsistence" and the tools to produce it. Hence, the worker's means of subsistence do not derive irom natare per se, but indirectly from nature, and directly from the means of employment (and wages subsequently earned for selling labor-power) gained from owners who, again, control the society's production of means of subsistence. Accordingly, class struggle for the means of subsistence is actually class struggle for control and ownership of the forces of production, if the focus is general and upon longrun necessary transformation in society; if the focus is on day-to-day survivel, this writer thinks it appropriate to say struggle is for the means of employment. (Marx might agree but would perhaps add that if workers became conscious of the true nature of relations of production, the daily struggle for means of employment would be seen as part of the long-run struggle between classes.)<smiles>[Z17][14CH2][14CH2][14CH2]</smiles> 
materialism, sublimated by the dominating presence of the conscious human spirit; but it is conditioned by the material facts of the production of the means of life. $n^{22}$

An uncritical look at Marx's reasoning system might lead to the conclusion that social order is determined by the modes of production. The modes of production are the basis of social institutions and comprise the driving force of society whose necessary transformations make for social progress. However, since modes of production condition particular relations of production, and class is a relation of production, class struggle must be included as a cracial driving force of social progress. Recall that class struggle operates not at a level of brute force, but at the level of human consciousness; where the process of valuation of material production of industry takes place. Veblen regards distinguishing class struggle from the brute forces of production as a logical necessity for Marx to make to avoid a logical trap that would have reduced all dialectical to brute material force and accordingly would have led to a Darwinian position on change as unconscious process. 23

Veblen thinks that without separating buman conscious valuation of material production of industry the dialectical siruggle would appear unconscious and an irrelevant conflict of brate matertal forces. This would have been essentially an interpretation in terms of cause and

${ }^{22}$ Ibid.

23 Because Darwin derived inspiration and influence from Malthus, Marx would have ended up reasoning human social conditions to be functions of natural law; yet he rejected natural law as controlling man. 
effect without recourse to the concept of class struggle; again this would have led to a concept of evolution in the Darwinian sense. Darwinian evolution would have prevented the class struggle from being the focal point of social change, hence the necessary method of social progress.

It would have led as Darwinism has, to a concept of a process of cumulative change in social structure and function; but this process, being essentially a cumulative sequence of causation, opaque and unteleological, could not, without infusion of pious fancy by the speculator, be asserted to involve progress as distinct from retrogression nor to tend to a "realisation" or "self-realisation" of the human spirit or anything else. 24

Thus, Marx is led by his logic to a world-view of social order as forming through conscious class struggle.

This background on Marx will prove quite useful in enhancing appreciation of Marx's population thought which follows after noting below some key notions used in and underpinning his treatise on capitalism.

The analysis of capitalism begins with the theory of value which is carried forward thereafter as an important element in all future analyses in his treatise. Value is considered self-evidently to be equal to labor cost. Under the auspices of historical materialism, the means and relations of production in force at a giten time must necessarily be noted to determine the character of class struggle for that given time. This must be kept in mind for it conditions Marx's view of the production of goods as the output of the (progressively) 
unfolding life of man in society. Because of these conditions, the nature of value has some twists that results in the basic self-evident value not being the entire story. The whole story of value involves development of the following notions: real value, exchange value, and surplus-value-absolute and relative forms.

Real and exchange value. The real value of the product of industry is the amount of labor put into its construction regardless of social definitions of the value. Since for social man reality has another dimension than that derived from brute forces of production, i.e. consciousness affected by the means of production, real value is augmented by the value which is attached through social consciousness; and this latter from of value may not be equivalent to the real productive value.

Real value is a fact of production and holds regardless of systems or methods of production. Exchange value is that value arising from the involvement of social consciousness and the distribution of products in society. Exchange value expresses the real value more or less adequately depending upon how well the type of distribution in operation corresponds to the equities given by distribution. For example, if output of industry is distributed to productive agents strictly in proportion to their share in production, exchange value of goods would reflect their real value. However, under capitalism distribution is not largely based on such equities of production and the exchange value of goods can express real value only very roughly. Under socialism, in theory, the laborer would get the full product of his labor and exchange value would be real value. 25 
Surplus-value. Marx recognized that merely concepts of real and exchange value were inadequate in themselves to explain the phenomenal growth of capitalistic society. Another concept of value was necessary to explain growth and it followed directly from the concepts of real and exchange value; it was surplus-value. 26 The source of surplus-value derives from production processes. The labor power expended in production is itself a product having a substantial value corresponding to its own labor-cost. By the potential for discrepency arising between real and exchange values, the value of the labor-power expended and the value of the product created by its expenditure need not be the same. The discrepancy is a surplus product of labor; arising from the discrepancy between labor-cost and value of the product created it cannot go to the laborers (because they do not own the means of production ${ }^{27}$ ) so it

${ }^{25}$ Veblen notes that two corollaries of the theory of value as developed by Marx are (1) the doctrine of the exploitation of labor by capital and (2) the doctrine of the laborer's clain to the whole product of his labor (Veblen, p. 412). Note also that the Natural Rights background of Marx is influencing him here because only by viewing man as imbued with certain rights, like the right to revolution, to equality, to liberty, could it be argued that the laborer was entitled to the whole product of his labor. Here again is another point of disputation between Marx and Malthus since Malthus regarded private property as essential to the perpetuation of society and economy while Marx clearly thought private property was the cause of the illness of society, with health restored by eradication of private property.

26 Two points need emphasis: (1) Surplus-value is synonymous with capital. It is the goal of the capitalist to maximize surplus-value for it is the unearned increment that the capitalist keeps for himself; it is profit. (2) It has been said that Marx thought his only significant original contribution was that of the concept of surplus-value. In fact, the French writer Chastellux noted the concept before him. To this writer Marx's originality lies in his creative synthesis of unrelated or marginally related ideas developed before him into a powerful new theory, and not in whether he was responsible for inventing a new idea per se. 
becomes profits of capitalists, and the source of its further accumulation or increase. 28 Accumulation or increase can take two forms, (1) absolute surplus-value, and (2) relative surplus-value. Absolute surplus-value can be expressed as follows:

The prolongation of the working-day beyond the point at which the labourer would have produced just an equivalent for the value of his labour-power, and the appropriation of that surplus-labour by capital, this is production of absolute surplus-value. 29

Absolute surplus-value forms the general groundwork of the capitalist system, and the starting-point for the production of relative surplus-value. Absolute surplus-value presumes the work day is divided into two parts; (1) necessary labor and (2) surplus-labor. Absolute surplus-value, in itself, means capital can only expand as far as surplus-labor of the working day will allow. Changes in production

27 See Marx, Capital, I, Ch. VIII, especially pp. 184-85.

${ }^{28}$ See Marx, Capital, I, Ch. VII \& XVI. Note: As has been pointed out earlier, the source of surplus-value derives from the production process, in which labor-power is inextricably involved. In the creation of surplus-value, the laborer must not be forgotten. In the capitalistic system, the laborer produces, not for himself, but for capital. Marx says of the laborer: "It no longer suffices, therefore, that he should simply produce. He must produce surplus-value. That labourer alone is productive who produces surplus-value for the capitalist, and thus works for the self-expansion of capital." Marx concludes:

"Hence the notion of a productive labourer implies not merely a relation between work and useful effort, between labourer and product of labour, but also a specific, social relation of production, a relation that has sprung up historically and stamps the labourer as the direct means of creating surplus-value." (p. 509.)

${ }^{29}$ Ibid., p. 509. 
methods which prolong surplus-labor by shortening unit production time is the basis for overcoming this limitation; is, in fact, production of relative surplus-value. Where absolute surplus-value turns exclusively upon the length of the working day, relative surplus-value is the revolutionization of technical processes of labor, and the composition of society. Marx regards relative surplus-value to be the real source of subjection of labor to capital. Ultimately absolute and relative surplus-values are the same because both produce surplus-labor from which surplus-value emanates. The difference lies in the source of the produced surplus; relative surplus-value having much more potential for expansion than absolute surplus-value. 30

Surplus-value is the source of grave problems for capitalistic production and the basis for explaining population processes without need for reliance upon natural law, hence, in a fashion offering an alternative to Malthus. Since laborers may be suddenly pushed out of employment by technical revolutions, and/or since laborers generally are unable to buy the whole product of their labor (because wages are measured by the value of labor-power rather than by the exchange value

${ }^{30}$ If accumulation of capital was limited merely to absolute surplus-labor, clear limits would be imposed requiring continual additions to the labor force to increase the quantity of surplus-value. Accordingly, the problem of population excesses would not exist because big populations would be necessary for accumulation of capital. Absolute surplus-value is not the significant element, however. Relative surplus-value is the important process for it permits capital to expand in qualitative jumps through technical revolutions. Changes due to technical revolutions often reduce demand for labor while simaltaneously increasing the magnitude of accumulation of capital. In Marx's discussion of population, it is relative surplus-value (an essentially variable constituent) and not absolute surplus-value (an essentially fixed constituent vis-a-vis relative surplus-value) that is significant. 
of the product of labor sold on the open market) capitalists are unable to sell the whole produst of industry continuously at its full value. It is from this condition that fluctuations in production occur in capitalistic economies and from such fluctuations that the implied Marxian theory of population takes its form. Discussion of population is made through discussion of capitalistic accumulation for it is the phenomenon in which is found the heart of fluctuations in a capitalist economy which affects population processes.

\section{CAPITALIST ACCUMULATION AND POPULATION}

The heart of the population thought of Marx, as noted, suddenly pops out of his discussion of the general law of capitalist accumulation. It will be necessary to consider this discussion carefully. To do so, some initial points on production and reproduction and relations of labor to capital will be presented which in turn will flow directly into discussion of capitalist accumulation and population. 31

With the theory of value set, Marx more or less begins ${ }^{32}$ discusm sion of the process of capitalist accumulation with the idea of simple reproduction. For Marx, the process of production must be ongoing;

31 The ultimate end of this argument is Marx's articulation of the causes of the collapse of capitalism. Veblen excellently summarizes Marx's argument (Veblen, pp. 426-27). This matter will not be discussed further in this chapter.

${ }^{32}$ If, as stated in this chapter, it is true that Marx's thought is an integrated system which must be viewed holistically, then Marx on population should be examined from the very beginning-page one of Capital. The critical student should make his inquiries from page one for fullest appreciation of Marx. However, for purposes of this study, it is sufficient to consider Marx beginning his population thought with simple reproduction. 
periodically the same phases of the process muct be repeated. For example, the hardware of production mast be replaced after a time because it wears out. Also, because consumption is a necessity, continuous renewal of products of consumption is necessary. Accordingly, every social process of production is concurrently a process of reproduction. Reproduction as a necessity means a definite part of each year's production must be put back into the means of production. This is essential to maintain the "operationality" of the means of production. Marx regards reproduction in capitalistic society to be, necessarily, capitalistic; as in production the labor-process figures as a factor in the self-expansion of capital, so in reproduction the labor-process figures as the means of reproducing capital.

Thus, labor's relation to capital plays a crucial role. Marx elaborates the role of labor in five points. Point one: Labor becomes part of capitalistic accumulation. The purchase of labor-power for a fixed period precedes the actual process of production. This action is constantly repeated at the close of the stipulated production period. The laborer remains unpaid through the stipulated period, collecting remuneration only after his labor-power is expended and realized in commodites both of value and surplus-value. In the process, the laborer not only produces surplus-value, which is appropriated by the capitalist, but also, before it flows back to him as wages, the total fund out of which his pay is taken out as part. The above relationship continues only so long as it results in reproduction of this fund. What actually is flowing back to the laborer as wages is a portion of the product continuously being reproduced by him. It may be true that 
money is merely a portion of the value product of his labor transferred into money. When looked at as a relation between classes instead of individuals, Marx says,

The capitalist class is constantly giving to the labouring class order-notes, in the form of money, on a portion of the commodities produced by the latter and appropriated by the former. The labourers give these order-notes back just as constantly to the capitalist class, and in this way get their share of their own product. 33

Marx concludes,

Variable capital ${ }^{34}$ is therefore only a particular historical form of appearance of the fund for providing the necessaries of life, or the labour-fund which the labourer requires for the maintenance of himself and family, and which, whatever be the system of social production, he must himself produce and reproduce. 35

Point two: Capitalistic production being reproduction communally reproduces the class relation between capitalist and labor. On the one hand, the process of production incessantly converts material wealth into capital, into means of creating more wealth. On the other hand, the laborer is the same when he leaves as when he entered the production process; namely, a source of wealth.

Since the process of production is also the process by which the capitalist consumes labour-power, the production of the

${ }^{33}$ Marx, Capital, I, p. 568 .

34/Marx defines variable capital as the labor-cost incurred by the capitalist in producing commodities. See Capital, I, p. 613. This will be discussed further in this chapter later on.

${ }^{35}$ Ibid., p. 568 . 
labourer is incessantly converted, not only into comodities, but into capital, into the value that sucks up the valuecreating power, into the means of subsistence 36 that buy the person of the labourer, into the means of production that command the producers. 37

The labourer produces the objective material wealth that forms into capital and the capitalist constantly produces labor-power; i.e. laborers make the wealth that is appropriated by capitalists. Under the dictates of necessity for reproduction, the capitalist reinvests some wealth to pay for the laborer who, in production, creates more wealth. Consequently, while the laborer produces objective material wealth, the capitalist produces the subjective social relationship of capitalist and laborer, actually wage-laborer.

Point three: In the relation of capitalist to laborer the worker plays a two-fold consumer's role which binds the class of laborers to capitalist production. While producing the laborer consumes, by his labor, the means of production; he converts them into products with a higher value than that of the capital advanced. This is productive consumption; a class consumption derived from a class function. But the individual worker secures his own survival as well; he turns the money paid him for his labor into means of subsistence for himself. Thus, he engages in individual consumption. When this aspect of the relation of capitalist to laborer is viewed at the level of class relations between the two, the following appears:

${ }^{36}$ It is very important to keep in mind that means of subsistence, for Marx, is actually means of employment, and, indirectly, means of production.

$$
\text { 37 Marx, Capital, I, p. } 571 \text {. }
$$


By converting part of his capital into labour-power, the capitalist augments the value of his entire capital. He kills two birds with one stone. He profits, not only by what he receives from, but by what he gives to, the labourer. The capital given in exchange for labour-power is converted into necessaries, by the consumption of which the muscles, nerves, bones, and brains of existing labourers are reproduced, and new labourers are begotten. (This writer's emphasis.) Within the limits of what is strictly necessary, the individual consumption of the working-class is, therefore, the reconversion of the means of subsistence given by capital in exchange for labour-power, into fresh labour-power at the disposal of capital for exploitation. It is the production and reproduction of that means of production so indispensable to the capitalist: the labourer himself. 38

Point four: The necessity of labor-power for production places the capitalist in need of the laboring class; but the relation, being one focused upon extending wealth of the capitalist to the greatest possible lengths, precludes the capitalist's interest being more than strictly economic; therefore, the capitalist is interested in maintaining subsistence minimums. Marx says,

The maintenance and reproduction of the working-class is, and must ever be, a necessary condition to the reproduction of capital. But the capitalist may safely leave its fulfillment to the labourer's instincts of self-preservation and propagation. 39 (This writer's emphasis.) All the capitalist cares

$$
{ }^{38} \text { Ibid., p. } 572 \text {. }
$$

${ }^{39}$ In this statement lies an ultimately insoluble mystery. Did Marx mean to use the expression "labourer's instinct for self-preservation and of propagation" metaphorically or literally? To this writer, it is impossible to tell by the tone of Marx's writing which he intended. If Marx intended the expression literally, two important revelations would appear. First, Marx would admit the influence of natural law on man, thus inviting two questions; (a) does not this appear to be a gross inconsistency with the underpinnings of his reasoning system? and (b) if natural laws do affect man, what criteria is there for determining which laws man is subject to and which he "escapes by producing?" Second, it would mean that the source of population growth would not be in dispute between Marx and Malthus; that instead, the essential issues disputed would be over the source and 
for, is to reduce the labourer's individual consumption as far as possible to what is strictly necessary, and he is far away from imitating those brutal South Americans, who force their labourers to take the more substantial, rathern than the less substantial, kind of food. 40

Marx goes on to say that the capitalist considers only that amount of the laborer's individual consumption to be productive which is requisite for the perpetuation of the class, and which therefore must take place in order to secure labor-power for the capitalistic means of production. Consequently, anything the laborer consumes in excess of subsistence minimums is unproductive consumption (and ultimately cuts into the amount of surplus-value produced for appropriation by the capitalist).

Point five: The nature of the capitalist-laborer relation serves to perpetuate labor-power by forcing the worker to constantly return to the labor-market. The individual consumption of the laborer provides the means for his maintenance and reproduction; this insures the perpetuation of the capitalistic production process. Individual

nature of poverty. However, the critical question would arise, if Marx accepted the same principles as Malthus with regard to the source of population growth, how would he reach such profoundly different conclusions concerning the consequences of population growth than Malthus? This writer thinks part of this answer to this question lies in Marx's twisting the use of natural law to either entirely or partially exclude it from affecting social man. Thus, the issue of how Marx views the relation of natural law and man appears to be crucial to the validity of his population argument. More on this point will be developed in this chapter, and this issue will figure heavily in the argument advanced in the next chapter; wherein it will be argued that Marx meant this expression literally and that as a consequence, the gross inconsistencies arising in Marx can only be resolved by looking at Marx from a different angle of view.

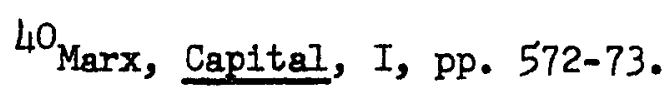


consumption, therefore, secures, by the annihilation of the necessaries of life (which the laborer must constantly reproduce) the continued commitment (or, says Marx, "reappearance") of the workman to the labormarket. This also perpetuates capitalistic production.

On the heels of the above discussion Marx advances his first strong reactions to Malthus. Mary makes it clear that he regards the Malthusian argument to be rooted in the utilitarianism of Bentham (whom he castigates as reproducing "in a dull way" the principle of utility stated with esprit by Helvétius and other Frenchmen ${ }^{41}$ ) and designed as an apology for the behavior of the capitalist class. Marx regarded the Malthusian analysis to be an attempt to represent variable capital as a fixed magnitude. Marx says,

The material of variable capital, i.e., the mass of the means of subsistencelt2 it represents for the labourer, or the so called labour-fund, was fabled as a separate part of social wealth, fixed by natural laws and unchangeable. 43

${ }^{41}$ Recall that Helvétius was Malthusian in his view of population and food supply relations. This point takes on importance in the next chapter.

42 Unless read carefully, this point might be confusing. It must be born in mind, to reiterate for emphasis, that Marx and Malthus meant different things by the term "means of subsistence." For Malthus, it amounts to food supply for the most part gained from production but dependent upon natural laws which dictate supply and which ultimately fix supply to a limited, largely inelastic, quantity despite human abilities to make some modifications through technology; for Marx "means of subsistence" has no such inelastic limits but instead is very elastic, replete with potential for expansion in quantity because limits are not viewed as built into nature but rather lie in man and his social organization. Since Marx regards man as able to control nature to an ever increasing degree through production, fixed quantities and limits by natural law are absurdities. (Note this does not deny natural law but merely argues that it can be circumvented.) In this sentence, this writer thinks Marx translates Malthus' use of the term directly into his own use of the term and by doing so may have misrepresented Malthus 
However, this critical reaction to Malthus amounts to just the beginnings of Marx's critical reaction. More powerful, or stronger, criticism derives from the substance of Marx's explication of the general law of capitalist accurmalation and the population thought that pops out of it.

Marx's discussion of the general law of capitalist accumulation, which will be followed quite closely and is presented in summary here, is composed of four main sections, with a fifth section devoted to illustrations of the law of capitalist accumulation, which consider (1) "The increased demand for labour-power that accompanies accumulation, the composition of capital remaining the same," (2) "Relative diminution of the variable part of capital simultaneously with the progress of accumalation and of the concentration that accompanies it," (3) "Progressive production of a relative surplus-population or industrial reserve army," and (4) "Different forms of the relative surplus-population and the general law of capitalistic accumulation."4h

and may have misinterpreted Malthus in his use of Malthusian theory. This position is also the basis for Marx's rejection of Malthus' postulate that population grows geometrically and food arithmetically. If production were properly organized, Marx argues, food supply would keep pace with population growti because each man produces more than he needs, and man is not bound by nature's laws. (See Meek, p. 127ff.)

43 Marx, Capital, I, p. 610. Note, the development of the general law of capitalist accumulation refutes this representation of variable capital as a fixed magnitude.

${ }^{44}$ It is not essential to an understanding of Marx on population to consider his illustrations of the law of capitalist accumlation; hence the omission of consideration of that section of Marx's argument in this chapter.

The remaining part of this chapter refers to Marx's work in Capital, vol. I unless otherwise stated when Marx's name alone is noted. 
Before beginning the discussion of capitalist accumulation and population, it will be useful to note some terms used by Marx in articulation of the law. First, Marx distinguishes between two types of capital; (1) constant, (2) variable. Constant capital is the value of the means of production. Variable capital is the value of the labor-power, the sum total of wages, as it functions in the process of production. All capital is thus divided with the composition of living labor-power being determined by "the relation between the mass of the means of production employed, on the one hand, and the mass of labour necessary for their employment on the other."45 Finally, through different combinations of constant and variable capital, resulting from different degrees of technical efficiency of the means of production and different demands, in terms of numbers, for labor-power, the compositions of individual capitals invested in particular branches of production may be different. Marx stresses that his concern is not for the composition of individual capitals of particular branches of production, but with the composition of the "total social capital of a country."46 A consideration of the four sections dealing with the general law of capitalist accumulation and population now follow.

1. "The Increased Demand for Labour-power That Accompanies Accumulation, the Composition of Capital Remaining the Same."

As growth of capital occurs some of the surplus-value must be put into increasing the siza of the living labor-power (Marx says some additional capital must be retransformed into variable capital, or

$$
\text { 45 Marx, p. 612. } \quad{ }^{46} \text { Ibid., pp. 612-13. }
$$


additional labor-fund). If, all other circumatences remining equal, the composition of capital remains constant, then derand for labor must increase in proportion to the increase of captai; and the more rapidly capital increases, the more rapidly labor and trofease. Because capital produces yearly a surplus-value of wich a portion is added to the original capital, because this increfentizelp grows yearly, and because periodically expansion of the scale of Exortit ria introduction of new markets or creation of new wants occure, tise scele of accumalation may suddenly extend resulting in a deacal Fon Labor-power which exceeds the supply of the living working ciase. Jae reanit is that wages may rise and the life of the vorker Rey ingore. winile the working class in such a period may enjoy lifie exia tre relation betuteen the capitalist class and the working class any de peaceinl, the trendline of movement wherein the capitaliet, throng agpitalistic accumlation, grows is not altered. Marx says,

As simple reproduction constantly reprodicse the cepitalrelation tiself, $i . e$. the relation of catialiste on the one hand, and wage workers on the other, 30 zeprodaction on $a$ progressive scale, i.e., accumlation, reproduce the capitalrelation on a progressive scale, more capitaligte or larger capitalists at this pole, more vage-rorkere at that. The reproduction of a mass of labour-power, which wast incessantly re-incorporate itself with capital for that sepitel's relfexpansion; which cannot get free irora capltei, and whose enslarement to capital is only concealed by the variety of individual capitalists to whom it selle zisels, inis reproduction of labour-power forms, in fact, an ezential of the reproduction of capital itself. Accamaletion of capital is,

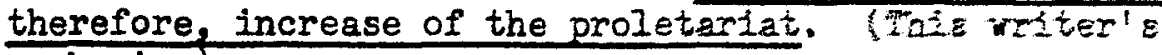
emphasis. 47

47 Ibid., p. 614. Marx says the "proletariet" is egnomymous with the wage.worker in this usage of the term (D.61la). Also, a point was emphasized because wituot camelol reading, it 
Under the above conditions of accumulation, the laborer is

relatively favored. The relationship of dependence on capital is

extended but not intensified; and the appearance of matually beneficial

interaction between capitalists and laborers clouds the reality beneath

the surface; that being exploitation of labor by capital, which remains

the principal basis for the interaction of the two classes. Marx says,

might be overlooked. This writer considers the sentence in the quote emphasized to be significant. Marx here ties population growth of the working class directly to the accumilation of capital. (Marx never considers population growth of the upper class. The immediate conclusion might be that he presumes all classes to grow the same way. This writer questions this because first, he emphasizes the focus on the working class, and second, his criticism of Malthus is largely focused around proving that poverty is not inevitable nor the fault of the poor born of overpopulation of the lower classes.) This point was primed by Marx's discussion of simple reproduction wherein he noted the working class was locked into the growth of capital; being an inextricably essential part of capitalistic production. This is now reinforced and made a direct function of capitalist accumulation. The point is a crucial one for it strikes to the heart of Marx's differences with Malthus. In contrast to Malthus, Marx, this writer thinks, bluntly implies that population growth follows the pattern of development of capitalistic production; and the growth of capital does not bend to the dictates of natural laws. Indeed, it has its own economic laws and implied is the notion that growth of capital need not necessarily be geometrical (although, of course, the goal is to maximize increase). Thus, this writer thinks, implied is the possibility that population growth need not always be geometrical, as Malthus would say. While the thrust of Marx's argument, its prime emphasis, is that under socialist economies the means of production can keep up with and even outpace population growth, it would not be inconsistent for Marx to argue that population growth, tied as it is to economic processes, could be a zero or negative growth if the economic system were set-up to compel this.

It seems surprising that such a point was not emphasized by Marx; it seems a stronger criticism of Malthus than simply arguing that socialism resclves population problems by keeping production ahead of population growth. If it is remembered that Marx was locked into a focus on social progress where no alternatives to it were considered, the surprise is less astounding. It bears pondering why the modern Marxists have not picked up this above point. No doubt part of the reason is a commitment to 19 th century beliefs in progress. But could some of the reason be that perhaps the modern Marxists are guilty of selective, prejudicial, study of Marx's thought?. A critical look at both Soviet and Chinese writings confirms this to be true. 
Labour-power is sold today, not with the view of satisfying, by its service or by its product, the personal needs of the buyer. His aim is augmentation of his capital, production of comodities containing more labour than he pays for...48

The purpose is augmentation of capital in a manner that insures the capitalist a steady flow of "something for nothing"-more labor than he pays for. The relationship, despite appearances, is preserved only so long as the means of production are preserved, as the labor-power reproduces its value as capital (and yields the unpaid increment, surplus-value). As capital accumulates and the magnitude of the relationship is inflated, the necessity of the constant re-selling and constantly extended reproduction of all wealth in the shape of capital is constantly fed back into the class relationship of capital to labor. The result is that despite high wages, capital accumulation continues (and if it did not, wages would drop). Therefore, the rise in the price of labor ultimately implies the following: either the price of labor keeps rising because its rise does not interfere with the progress of accumlation, or accumulation falls off because of excessive rises in the price of labor which serves to blunt the stimulus for accumulation. In the case of the latter circumstance, the very obstacle to accumulation is removed; for under the dictates of simple reproduction, when the labor-power falls to reproduce its value as capital, plus surplusvalue, the basis for the relationship of the class of capitalists and the class of laborers is removed. Accordingly, because labor needs employment to procure the means of subsistence, and capital needs labor as a basis for accumulation, the relationship is preserved through

$$
48 \text { Marx, p. } 618 .
$$


the price of labor falling and accumulation continuing.

As can be seen, the trend of accumulation of capital is not altered by a state of affairs favorable, temporarily, to the working class. The dependence of the working class appears as the real basis of class interaction. In the first case, the excess of capital makes labor-power insufficient but accumulation does not stop. In the second case, the diminution of capital causes the price of labor-power to be excessive; its price falls and capital continues to accumulate. The trendlines, therefore, are now clear; capital accumulation exhibits, figuraively, a linear vector moving to higher and higher levels. It accomplishes this by feeding on the dependence of labor on capital. Labor, figuratively, is locked into an oscillating movement caused by the changes in capital as it accumulates. If changes in the technical efficiency of production occurs where the same output can be achieved with fewer workers, and/or other changes occur increasing efficiency and reducing need for labor, then the price of labor goes down because those put out of work compete for fewer positions in the system of production. If demand suddenly increases, e.g. a new market is added, then more labor-power is needed and the fluctuation towards increased unemployment, and low price of labor-power reverses itself and moves toward high employment, and high prices of labor-power. All the while these fluctuations occur, capital accumlates (and before it ceases, or fluctuates toward regression, the economic forces in play manipulate the dependent working class by changing the price of labor-power). 49 At this point Marx has sufficiently framed his argument to launch ${ }^{49}$ Ibid., pp. 612-20. 
another salvo against the Malthusian economic and population position.

Marx states that the problem is the fluctuating price of labor-power and

not, as Malthus and others have interpreted, the emergence of first too

many and then too few laborers. Quoting Marx,

The law of capitalist production, that is at the bottom of the pretended "natural law of population," reduces itself simply to this: The correlation between accumulation of capital and rate of wages is nothing else than the correlation between the unpaid labour transformed into capital, and the additional paid labour necessary for the setting in motion of this additional capital. It is therefore in no way a relation between tiwo magnitudes, independent one of the other: on the one hand, the magnitude of the capital; on the other, the number of the labouring population; it is rather, at bottom, only the relation between the unpaid and the paid labour of the same labouring population. If the quantity of unpaid labour supplied by tine working-class, and accurnulated by the capitalist class, increases so rapidly that its conversion into capital requires an extraordinary addition of paid labour, then wages rise, and, all other circumstances remaining equal, the unpaid labour diminishes in proportion. But as soon as this diminution touches the point at which the surplus-labour that nourishes capital is no longer supplied in normal quantity, a reaction sets in: a smaller part of revenue is capitalised, accumulation lags, and the movement of rise in wages receives a check. The rise of wages therefore is confined within limits that not only leave intact the foundations of the capitalistic system, but also secure its reproduction on a progressive scale. The law of capitalistic accumulation, metamorphosed by economists into a pretended law of Nature, in reality merely states that the very nature of accumulation excludes every diminution in the degree of exploitation of labour, and every rise in the price of labour, which could seriously imperil the continual reproduction, on an ever-enlarging scale, of the capitalistic relation. It cannot be otherwise in a mode of production in which the labourer exists to satisfy the needs of self-expansion of existing values, instead of, on the contrary, material wealth existing to satisfy the needs of development on the part of the labourer. 50

Based upon the arguments of this first section, and the sudden

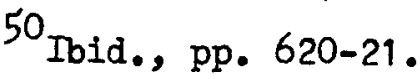


critique of Malthusian population theory that pops from the heart of this section in the form of the above quote, three significant points of comparison between Marx and Malthus so far appear. First, Marx considers Malthus' natural law of population as really an economic relation of the capitalistic mode of production. Second, the Malthusian view that economic processes and population growth are independent variables is incorrect; the relation is really between socio-economic variables, the capitalist class and the laboring class, which interact through the relation between paid and unpaid labor of the same laboring population. Third, Marx implies that Malthusian checks on population growth, like misery, are not real checks. In their place Marx suggests the fluctuation of the price of labor (wages) affected by the lag of accumulation as a real check.

The above three points do not constitute the entirety of Marx's critical reactions to Malthus. More complex arguments ensue from his discussion of the "relative diminution of the variable part of capital simultaneously with the progress of accumulation of the concentration that accompanies 1t."

2. Relative Diminution of Variable Capital Simultaneously with Progress Accumulation and Concentration that Accompanies It After the capitalistic system has established itself in a general way, as accumulation occurs, a point is reached where "the development of the productivity of social labour becomes the most powerful lever of accumulation." 51 What occurs is a change in the productive power of

$$
{ }^{51} \text { Ibid., p. } 621 .
$$


labor such that it is increased so that a smaller quantity of labor will produce a greater quantity of work.

Apart from natural conditions and skills of independent and isolated producers, the degree of productivity of labor comes from the quantitative and/or qualitative output of one laborer, over a fixed time-span using a fixed "tension of labour-power." The output of the individual laborer increases with the increase in the productiveness of labor. The increase in productiveness of labor occurs at the expense of the absolute number of laborers employed; or, the subjective factor of the labor-process (the conscious living labor-power) diminishes as compared with the objective factor (the technical equipment).

Marx considers the above process an economic law; the law of the progressive increase in constant capital (the mass of the means of production) in proportion to the variable capital (labor-power). This is important because it comes into play to affect population in the next section. 52

The increased productivity of labor (and to some degree the increased constant capital) leads to more than just tir potential for

52 As productivity increases, it means more product comes from less labor; each laborer does more in less time. Accordingly, the machinery and equipment of the means of production, as they expand to increase productivity of labor, require less living labor-power to do the same amount of producing as before technical improvements and more raw material than before because the productive abilities of the machinery are greater. However, it is to be emphasized that the ratios between constant and variable capital constituents of the means of production are progressive and accumalative so that it does not mean production will reach a position where living labor-power is unneeded; merely that the quantity in proportion to the accumulation is inversely proportional to increases in the constant capital side of the means of production. 
greater accumalation of capital; it leads to the phenomenon of concentration which has an impact upon population (also to be seen in the next section). Two points of significance can be noted. First, while individual capitals form and reform, some into larger more concentrated units while others into smaller units, the process of accumalation of capital overall is unaffected; accumulation continues presenting itself on the one hand as an increasing concentration of the means of production and on the other hand as increasing command over labor.

Second, while accumulation and concentration are important ways that capital increases its quantitative and qualitative magnitude, another, more significant, mode of increasing magnitude appears in the form of centralization. Marx notes that individual capital attracts individual capital through competition fought by cheapening commodities. Larger capitals beat the smaller because they, through productivity of labor and scale of production, all other things remaining equal, can produce commodities cheaper. Further, the credit system becomes a new and powerful mechanism for centralization by drawing into the hands of individual and/or associated capitals money resources previously dispersed throughout society. The result is a dynamic capacity to expand scale of production suddenly and extensively (as well as intensively). Further, beyond merely focusing a dynamic potential for expansion, centralization processes extend and accelerate the making of revolutions in the technical composition of capital. Recall that technical revolutions have the effect of reducing the need for numbers of living labor-power through increasing productivity of labor. As a 
result, accumulation of capital carries with its increase in magnitade the ever increasing power to affect the supply of labor. First, through centralization, greater control over greater numbers and greater ability to affect greater numbers in one stroke occurs. Second, and perhaps most significantly, through centralization, the more extensive and rapid the technical revolutions, thus the more extensive and rapid the repulsion of living labor-power from the means of production. Marx says,

On the one hand, therefore, the additional capital formed in the course of accumulation attracts fewer and fewer labourers in proportion to its magnitude. On the other hand, the old capital periodically reproduced with change of composition, repels more and more of the labourers formerly employed by it. 53

\section{3. "Progressive Production of A Relative Surplus-population or}

Industrial Reserve Army."

Marx states the quantitative and qualitative processes by which capital accumulates and the resulting repulsion of labor from the meanz of production occurs in the following way:

The specifically capitalist mode of production, the development of the productive power of labour correspondingly to it, and the change thence resulting in the organic composition of capital 54, do not merely keep pace with the advance of accumulation, or with the growth of wealth. They develop at a much quicker rate, because more accumalation, the absolute increase of the total social capital, is accompanied by the centralisation of the individual capitals of which the total

53 Marx, p. 628.

54 Organic composition of capital is the complete composition of capital involving all constituent parts, i.e. variable and constant capital and the interaction of types of composition of capital. 
is made up; and because the change in the technological composition of the additional capital goes hand in hand with a similar change in the advance of accumulation, therefore, the proportion of constant to variable capital changes. If it was originally say $1: 1$, it now becomes successively $2: 1$, $3: 1,4: 1,5: 1,7: 1$, etc., so that as the capital increases, instead of $\frac{1}{2}$ of its total value, only $1 / 3, \frac{1}{4}, 1 / 5,1 / 6,1 / 8$, etc., is transformed into labour-power, and, on the other hand, $2 / 3,3 / 4,4 / 5,5 / 6,7 / 8$, into means of production. 55

Since demand for labor-power is tied directly to the growth of variable capital, and since variable capital shrinks as the magnitude of total capital expands, the economic need for living labor is, proportionally, constantly diminishing as total capital expands. This relative diminution of variable capital, ited to total capital growth, necessarily accelerates as total capital expansion accelerates. Marx says,

55 This writer considers the point made here quite pertinent to Marx's thought on population. Recall that Marx rejects the idea of natural law affecting man; that Marx rejects the view that population growth necessarily must outrun means of subsistence (food supply for Malthus and employment for Marx, remember); that Marx regards population growth to be locked into the nature of the capitalist system of production. Now observe the quotation. What Marx is saying is that Malthus' statistical ratio between population and means of subsistence is really an economic ratio of capital accumulation to employment 1 with actual size of population a dependent manifestation of the ratio changes of variable and constant capital as accumulation occurs. Therefore, it is not that population outruns means of subsistence, but that capital accumulation outruns the means of employment, the result being an increase of unemployment as the structure of organic capital changes. This point might be overlooked without critical reading. Finally, recall that capital accumulation is also linked to increase of the proletariat ( $p .614$ ) in real terms. This makes the Marxian explanation of population a bit tricky; unemployment, on the one hand, is produced by shifts in the structure of organic capital, and on the other hand, expansion of capital requires absolute increases in the size of the laboring population. Consequently, overpopulation is real, but it is only real in an economic sense; $1 . e$. the consequence, necessary and inevitable, of the operation of the capitalistic system of production. Clearly, then, Marx's reaction to Malthus is subtle, complex, and a more detailed challenge than previously explicated by students of Marx. 
This accelerated relative diminution of the variable constituent, that goes along with the accelerated increase of the total capital, and moves more rapidly than this increase, takes the inverse form, at the other pole, of an apparently absolute increase of the labouring population 56, an increase always moving more rapidly than that of the variable capital or the means of employment. But in fact, it is capitalistic accumlation itself that constantly produces, and produces in the direct ratio of its own energy and extent, a relatively redundant population of labourers, i.e., a population of greater extent than suffices for the average needs of the self-expansion of capital, and therefore, a surplus-population. 57 (Emphasized points added by this writer.)

56 Some further elaboration of a point made earlier is in order (see footnote 47, p. 130 of this chapter). By implication Marx excludes the capitalist class from his discussion of population. This points up yet another contrast to Malthus. Malthus' discussion of population growth was an attempt to rationalize poverty. Recall, Malthus stressed that poverty was the fault of the poor for reproducing themselves into poverty. Malthus did not devote attention to the ruling class but did imply that the ruling class could support its population growth (also there was indication that the ruling class was adept at fertility control, that Malthus was aware of it but would not condone it for religious reasons, hence, chosing to disregard it in his work; see G.F. McCleary, The Malthusian Population Theory, London: Faber and Faber, Itd., 1953, Ch. VIII). Marx implies by exclusion of discussion of the capitalist class that overpopulation was a class problem; i.e., with surplus-value increasing constantly, the capitalist class population could never outgrow their means of subsistence. Here again, the force of proportional growth of various constituents of capital comes into play; the more growth of capital, hence surplus-value, the more means of subsistence go to the capitalist class, the less to the working class. Lastly, implied is the idea that the means of subsistence would be the means of production, the products created, ard the surplus-value derived from it, in addition to the actual food supply produced.

Thus, Marx's discussion of population finds differences between him and Malthus on two major points: (1) that poverty is the fault of the poor, Marx argues that fault lies with capitalist production in general and the capitalist class in particular, and (2) that population problems are problems of class relations, in fact, are a problem of class struggle. It must be remembered that while a master scholar, Marx was committed to revolution also and believed that erasure of the capitalist class, the return of the laborer's full product to him, would eliminate problems of poverty and population.

These issues will be important in the next chapter. Increasingly evident is the indication that Marx's population thought is focused on social problems of poverty facing the lower classes. Accordingly, it appears inappropriate to consider Marx's thought on population to be the advancement of a theory of population. 
All of the preceding discussion now becomes the backdrop for the next points on population. Marx, up to this point, has built a stage and described the factors which give the process of capitalist accumulation its potential for extraordinarily dynamic expansion. In the course of doing so, he has elaborated economic reasons for concluding that surplus-population is actualiy an army of unemployed; on the one hand due to repulsion of labor from production by growth of technical efficiency, and on the other hand, due to the difficulty of absorbing additional laboring population ${ }^{58}$ steming from lack of need for more

$$
57 \text { Marx, p. } 630 .
$$

58 This writer thinks that at this point Marx recognizes that population actually increases in size. Marx is saying that capital accumulation ultimately tends to repel workars from employment and consequently, it makes it difficult for new workers to gain employment. The creation of surplus-population comes from economic processes forming the heart of capitalism. Marx recognizes additions to the size of population, recognizes that population problems arise because of it, i.e. additional laboring population is difficult to absorb, but couches the recognition in the context of the economics of capitalism, implying thereby that (1) it is capitalism's problem that additional number cannot be employed and (2) with necessary and inevitable termination of capitalism the problem of surplus-population will disappear. Here, then, is a clear indication of Marx's reaction to Malthus. He is not reacting to recognition that population growth is linked to food supply. This writer thinks Marx accepts the validity of the postulated relation of population to food supply (and the following chapter will elaborate reasons for this conclusion by this writer). He is reacting to claims that the social problem of poverty is inevitably the result of population growth which leads to an actual absolute surplus of people. Marx denies this. While population may grow, and it may depend upon food, food is produced. A basic Marxian assumption is that individuals can produce more than they can individually consume. Hence, the problem is not that production cannot supply (or keep pace with) the population's needs for subsistence, but that the mode of production at hand cannot supply the population with subsistence. Hence, poverty becomes soluble, a transitory problem, an ultimately unnecessary phenomenon and not, as Malthus would argue, a necessity, forever persistent and never resolvable save through some form of religiously based "moral restraint." It should be clear by now that many points of contrast exist between Marx and Malthus. They form an important part of the foundation of Ch.V. 
labor as the organic composition of capital changes. Now he advances discussion of the role of surplus-population in the process of capitalist accumulation. 59

59 The development of production is not a movement where all parts progress necessarily in the same manner, at the same rate. Accordingly, while large-scale centralization may be occurring in one sector of production, another may be growing slowly suffering from temporary stagnation in the improvement of technical efficiency. Many variations may be identifiable; the important point is that creation of surpluspopulation is not simultaneously and unilaterally occurring throughout society. While variations in progress exist, it does not mean that variations exist in the process of creation of surplus-population. It occurs as outlined. Marx emphasizes this point by concluding that what can be seen changing is the magnitude of the self-expansion of capital. As the magnitude increases, the power of capital to attract laborers when they are needed gets stronger as does its power to repel laborers from capital when they are not needed. Since the laboring population initially was the key to the development of capital, since capital depends upon unpaid labor to continue and grow, since the end result is the making relatively redundant, and surplus, of the laboring population "the laboring population therefore produces, along with the accumulation of capital produced by it, the means by which itself is made relatively superfluous, is turned into relative surplus-population; and it does this to an always increasing extent." (Marx, p. 631.) Marx says further,

"This is a law of population peculiar to the capitalist mode of production; and in fact every special historic mode of production has its own special laws of population, historically valid within its linits alone. An abstract law of population exists for plants and animals only, and only in so far as man has not interfered with them." (This writer's emphasis; Marx, p. 632.

However, Marx leaves more questions than he answers with the above points. First, Marx is negligent to a fault because he makes no further comments about differences between "historically valid within its own limits" population laws of other times and places. What were the laws for the feudal period? What were the laws for the Paleolithic man? Even more important, what are the laws for his communist society? Marx answers none of the above questions and this reinforces this writer's conclusion that Marx was not intent upon writing a theory of population. Second, here Marx makes it clear that his criticism of Malthus is for Malthus' position of advancing a law of population which is inextricably operating, largely uncontrollable by man, external to his social system, and forever the same. Marx's belief that man can control nature appears in this conclusion. However, Marx still does not 
If a surplus-population is a necessary product of the accumulation of wealth on a capitalist basis, "this surplus-population becomes, conversely, the lever of capitalistic accumulation, nay, a condition of existence of the capitalist mode of production. "60 Marx says,

It forms a disposable industrial reserve army, that belongs to capital quite as absolutely as if the latter had bred it at tis own cost. Independently of the limits of the actual increase of population, 61 it creates, for the changing needs of the selfexpansion of capital, a mass of human material always ready for exploitation. With accumulation, and the development of the productiveness of labour that accompanies it, the power of sudden expansion of capital grows also; it grows not merely because the elasticity of the capital already functioning increases, not merely because the absolute wealth of society expands, of which capital only forms an elastic part, not merely because credit, under every special stimulus, at once places an unusual part of this wealth at the disposal of production in the form of additional capital; it grows, also, because the technical conditions of the process of production themselves-machinery, means of transport, etc.,-now admit of the rapidest transformation of masses of surplus-product into additional means of production. The mass of social wealth, overflowing with the advance of accumulation, and transformable into additional capital, thrusts itself frantically into old branches of production, whose market suddenly expands, or into newly formed branches, such as railways, etc., the need for which grows out of the development of the old ones. In all such cases, there must be the possibility of throwing great masses of men suddenly on the decisive points without injury to the scale of production in other spheres. Overpopulation supplies these masses.

(Emphasis provided by this writer.)

rule out historically specific laws of population; yet he only advances a few such laws indirectly, as the result of the operation of capitalism.

60 Marx, p. 632.

61

The emphasized points suggest Marx recognized limits to population increase. Question: How can Marx deny an abstract law of population and still admit limits, or socio-economic checks? Ch. V examines this further.

${ }^{62}$ Marx, p. 632. Note: This is the first use of the term 
Now if overpopulation, the disposable industrial reserve army, is tapped, and directed to a sphere of production undergoing great expansion, does not the surplus-population diminish, making availability of a mass of reserve labor scarce? Well, yes and no. Yes, the reserve army is reduced as it is tapped; no, it is not reduced because capital accumalation is constantly repelling labor as organic composition of capital changes. Marx, in this regard, notes the characteristic movement of modern industry to be cyclical; having periods of average activity, production at high pressure, crisis, and stagnation. These phases are linked to phases in the industrial reserve army, which makes reformation of it a necessity as great as the existence of the industrial reserve army per se. Marx says, "In their turn, the varying phases of the industrial cycle recruit the surplus-population, and become one of the most energetic agents of its reproduction." 63 This phenomenon Marx considers to be only characteristic of a period of advanced capitalistic production. It could not occur during the infancy of capitalist development because the composition of capital changed quite slowly, 64 and did not occur in any other period of human

\footnotetext{
"overpopulation" by Marx; clearly Marx uses it differently than Malthus. Also implied is a criticism of Malthus, again along the theme running through Marx's entire argument and stressed many times in this chapter; namely, that population is an economic problem. It is because the accumulation of capital requires the availability of excess numbers to permit smooth operation of the system as it grows. Furthermore, Marx characterizes the phasic movement of the modern industrial development of capitalism as one of expansion and contraction; expension requiring a disposable mass of human material, but one which must be constantly regenerated, thus the movement of accumulation must have a period of contraction, or consolidation, where labor is repelled from capital to regenerate the industrial reserve army. See Marx, pp. 632-33.

$$
63 \text { Ibid., p. } 633 .
$$
}


history (though Marx neglects to explain why). Finally, with the advancement of capitalism the ability to make sudden leaps occurs, Iimits to exploitation are dispelled, and the surplus-population forms. The ability to make sudden leaps is impossible without the existence of "disposable human material, without an increase in the number of labourers independently of the absolute growth of population. ${ }^{65}$ In fact, the whole form of this period of production depends upon the constant existence, through transformation of a part of the labouring population into unemployed or half employed hands, of the industrial reserve army. Marx says this with such emphasis as to regard it an economic law of capitalism. "As the hearenly bodies, once thrown into a certain definite motion, always repeat this, so is it with social.

${ }^{64}$ The slow accumulation of capital meant that a corresponding growth in labor kept pace with development. Consequently, the slow growth period found a check to overpopulation in the natural limits of the exploitable laboring population. This limitation was only removed through forceful transformations in organic composition of capital such that labor is repelled from production.

This writer speculates that Marx may be Implying that no period before the period of advanced capitalism ever had overpopulation problems. Since Marx never devotes discussion to population in prior historical periods, it mast remain an uncertainty. However, if he did think there were periods of overpopulation prior to advanced capitalism he would be hard pressed to prove that overpopulation is strictly a capitalist phenomenon (since he emphasized that each historical period had its own laws of population). If he thought that the advanced capitalist period was the only one with overpopulation, he would be hard pressed to explain why famines persisted throughout history. Since it appears Marx admits a relation between food supply and population, he might argue that men in history failed to control nature as fully as they could and that overpopulation in earlier periods was the result of an insufficient productive domination of nature which was finally resolved in the capitalist period. However, to invoke this explanation would require admission of population's dependence on food which in turn would raise questions about Marx's position vis-a-vis Malthus.

$$
65 \text { Marx, p. } 633 .
$$


production as soon as it is once thrown into this movement of alternate expansion and contraction." 66 In this light, Marx concludes that surplus-population is a necessary condition of modern industry. ${ }^{67}$ Marx's conclusion that surplus-population is a necessity of modern industry up to this point has held the relationship between the number of laborers and variable capital constant, in fact, at parity. But variations in the structure of this relationship (i.e. processes which extend and intensify exploitation of labor) evoke further growth of the surplus-population.

The discussion of such variations begins with Marx emphasizing that capitalist production cannot content itself with just the quantity

${ }^{66}$ Ibid.

${ }^{67}$ At this point, Marx introduces a criticism of Malthus in his text. This is the first such inclusion of a critical note regarding Malthus, where Malthus' name is actually mentioned, not found in a footnote in all of the preceding discussion. Marx's criticism of Malthus is to imply that Malthus admits Marx's validity. Marx says, "Even Malthus recognises over-population as a necessity of modern industry, though, after his narrow fashion, he explains it by the absolute over-growth of the labouring population, not by their becoming relatively supernumerary." (p. 634.) Thereupon, Marx widens his criticism to include those that embrace Malthus; using the rubric "Political Econony" for his position, Marx says,

"After Political Economy has thus demonstrated the constant production of a relative surplus-population of labourers to be a necessity of capitalistic accumulation, she very aptly, in the guise of an old maid, puts in the mouth of her 'beau ideal' of a capitalist the following words addressed to those supernumeraries thrown on the streets by their own creation of additional capital:- 'We manufacturers do what we can for you, whilst we are increasing that capital on which you must subsist, and you must do the rest by accommodating your numbers to the means of subsistence." (pp. 634-35.)

Thus, Marx attempts to refute Malthus by showing that Malthus' position 1s, in fact, the capitalist's position regarding the unemployed, or poor, and the so-called over-populated working class. 
of disposable labor-power provided by the natural increase of population. 68 Because of its dynamic capabilities, it must have free play with an industrial reserve army which is independent of limits set by

${ }^{68}$ Here Marx can be seen reasoning from the assumption that production (and especially the process of capitalist accumulation) can (and does) outpace the natural growth of population. It is for this reason that Marx's thought shows no worry whatsoever for the possibility of a real overpopulation, of the Malthusian type, occurring.

Engels, however, did not appear to hold Marx's confidence (and since there was almost a lifetime of scholarly interaction between Marx and Engels this writer is inclined to think Marx nursed some doubts about the solidness of his assumption). In a revealing letter to Kautsky, 1 February 1881, Engels said,

"There is, of course, the abstract possibility that the number of people will become so great that limits will have to be set to their increase. But if at some stage communist society finds itself obliged to regulate the production of human beings, just as it has already come to regulate the production of things, it will be precisely this society, and this society alone, which can carry this out without difficulty. It does not seem to me that it would be at all difficult in such a society to achieve by planning a result. which has already been produced spontaneously, without planning, in France and Lower Austria. At any rate, it is for the people in the communist society themselves to decide whether, when, and how this is to be done, and what means they wish to employ for the purpose. I do not feel called upon to make proposals or give them advice about it. These people, in any case, will surely not be less intelligent than we are.

"Incidently, as early as 1844 I wrote (Deutch-Franzosische Jahrb., p. 109): 'Even if Malthus were altogether right, it would still be necessary to carry out this (socialist) reorganization immediately, since only this reorganization, only the enlightenment of the masses which it can bring with it, can make possible that moral restraint upon the instinct for reproduction which Malthus himself puts forward as the easiest and most effective counter-measure against overpopulation. '" (Meek, pp. 120-21.)

This is the only place, in the knowledge of the writer, the possibility of overpopulation is considered by Engels, or Marx. Out of this consideration three points appear. First, it appears clear that at least Engels, and probably Marx, were worried about the possibility of overpopulation and wanted to take it into account without having to concede Malthus' validity. Second, in the last paragraph of this letter, Engels uses the term "instinct for reproduction" and it is 
natural increase.

With the industrial reserve army so independent, several things may (and will) occur. The number of laborers capital requires over time may remain unchanged, or even fall, while variable capital increases. "This is the case if the individual labourer yields more labour, and therefore his wages increase, and this although the price of labour remains the same or even falls, only more slowly than the mass of labour rises." 69 Marx notes that it contributes to accumulation of capital to squeeze out more labor for a smalier quantity than add more laborers. If additional labor is added, it increases the outlay of constant capital and temporarily reduces the level of capital accumulation. As the scale of production rises, there is increased pressure to avoid additions of living labor for the constant capital outlay for making additions is that much greater. Accordingly, the emphasis, born of necessity of accumlation, is to increasingly exploit existing labor vis-a-vis adding more labor. In this same regard, all manner of actions which contribute to extending and intensifying exploitation of labor quantities employed in production are favored. The result of favoring

unclear if he Intends the use as metaphorical or literal; recall this question from footnote 39, p. 125 of this chapter. Again, if he uses it literally, the problem with the principle of natural law appears. Third, as Engels notes the problem of overpopulation, his solution is the creation of a popular residual category used by many scholars; namely, passing the problem off to the next generation; in this case, the escape route is recourse to the intelligence of tomorrow's socialist people. Accordingly, what appears then is recognition of the problem of overpopulation, and virtual admission of inability to deal with it successfully within the boundaries of Marx's reasoning system.

$$
{ }^{69} \text { Marx, p. } 635 .
$$


such efforts is a tendency for the capitalist to progressively replace skilled labor with less skilled, "mature labour with immature, male by female, that of adults by that of young persons or children. " 70 This also means that the same capital can buy a greater mass of labor-power. Such action means additions to laboring populations in a manner that makes addition to constant capital less costly, hence favoring continued accumulation of capital. The process also has great impact upon the stracture of, as well as the reformation of, the industrial reserve army.

The above striving for the greatest exploitation of labor by the capitalist constitutes a stimulation to a more rapid production of a relative surplus-population than conditioned by natural increase alone, or by technical revolutions and their impact upon accumulation through changing the organic composition of capital (thus insuring that capitalistic production maintains a quantity of disposable labor-power greater than provided by the slow process of natural increase, hence providing a source for creation of disposable laboring populations more quickly than accumalation can occur during periods of sudden leaps of expansion). And it means that capital increases its supply of labor more quickly than its demand for laborers; which in turn works to the benefit of the capitalist at the expense of the laborer, because:

The overwork of the employed part of the working-class swells the ranks of the reserve, whilst conversely the greater pressure that the latter by its competition exerts on the former, forces these to submit to over-work and to subjugation under the dictates of capital. The condemnation of part of the

${ }^{70}$ Ibid. 
working-class to enforced idleness by the over-work of the other part, and the converse, becomes a means of enriching the individual capitalists, and accelerates at the same time the production of the industrial reserve army on a scale corresponding with the advance of social accumulation. 71

The wages of laborers are directly tied to the trend of the extension and intensification of exploitation of labor. While most wage theory up to Marx tied wages to demand by production and/or supply of labor in terms of absolute numbers, Marx translates absolute number relations into the conception of the relative surplus-population. So while Marx agrees with the historical trendline of wage theory connecting the price of labor to quantity of laborers, he varies from the trendline by synthesizing his brand of relativism into the trend of wage theory. Marx says the general movement of wages is "exclusively regulated by the expansion and contraction of the industrial reserve army," which in turn corresponds to periodic changes in the industrial cycle. 72

With concluding remarks on wage relations derived from the existence of the industrial reserve army, Marx ends his discussion of the "progressive production of a relative surplus-population or industrial reserve army." However, discussion on forms of the relative surpluspopulation follows which adds more dimension to Marx's thought on

71 Here Marx explains poverty and misery as the result of capitalist exploitation and conditions that throw the oppressed into competition with one another which minimizes the desirability of employment and maximizes surplus-value for the capitalist. Clearly, this contrasts to Malthus' explanation of poverty and misery as a function of the principle of population.

72 Marx, p. 637. Further discussion of Marx's wage theory does not bear upon the question of population and hence is omitted. 
population. In this upcoming section, important criticism of Malthus' views on the sources of poverty and pauperism emerge, as well as important notes on Marx's views of the sources of natural increase.

4. Forms of the Relative Surplus-population

There are three forms of the relative surplus-population; floating, latent, and stagnant. Floating relative surplus-population derives from an industrial section periodically repelling workers, then reattracting them. A second aspect of this form of relative surplus-population is that part of the surplus-population "floats" toward where capital moves; i.e. capital emigrates, and the unemployed also emigrate, following the movement of capital. Under conditions of the floating form of the industrial reserve army, Marx says, the female population grows more rapidly than the male.

In automatic factories, as in all the great workshops, where machinery enters as a factor, or where only the modern division of labour is carried out, large numbers of boys are employed up to the age of maturity. When this term is once reached, only a very small number continue to find employment in the same branches of industry, whilst the majority are regularly discharged. This majority forms an element of the floating surpluspopulation, growing with the extension of those branches of industry. Part of them emigrates, following in fact capital that has emigrated. One consequence is that the female population grows more rapidly than the male, teste England. That the natural increase of the number of labourers does not satisfy the requirements of the accumulation of capital, and yet all the time is in excess of them, is a contradiction inherent in the movement of capital itself. 73

Some questions arise from the above quote: (1) Why is the female population larger than the male? Does it have to do with emigration or ${ }^{73}$ Ibid., p. 641. 
with the nature of the automatic factory? (2) How does natural increase relate to the first part of the paragraph's discussion of the automatic factory's role in contributing to floating relative surplus-population? Marx makes the point that female population is larger than the male population and vaguely attaches cause to emigration or the exploitation of labor by capital. Two points may help clarify Marx's idea, both of which he implies in his discussion. First, Marx could be assuming that because young boys work in factories, their mortality rate is higher, thus causing the disproportion between males and females. Marx does consider mortality rates for the upper middle class (average age of death calculated at 38 years) vis-a-vis that of the laboring class (average age of death calculated at 17 years). 74 While this comparison is made for the classes as a whole, and not specifically for young boys, when it is combined with Marx's earlier notation that the tendency for exploitation of labor by capital was to press the cheapest labor (women and children) into service, it makes the view that mortality rates for males being higher than females as the basis for sex ratio discrepancy favoring females plausible, if it is assumed that children pressed into service were predominantly male. If it is assumed that an equal mix of male and female children were pressed into service with women, the question would arise, would not this counterbalance losses of young boys? Marx's clarity leaves much to be desired on this point. Hence, a second point seems needed. Marx emphasizes exploitation of labor pressing women and children into service at the expense

$$
74_{\text {Ibid., pp. } 641-41}
$$


of adults. 75 Now, if females and children were employed, then those repulsed from labor processes would be predominantly adult males. The floating relative surplus-population would be, therefore, more male than female, and the unemployed surplus-population which emigrated following capital would be, therefore, more male than female. Accordingly, the sex ratio would favor females over males. It seems to this writer that a combination of the two points serves to make clear Marx's intended meaning; although, at base, since Marx himself was quite unclear, the above two points must be filed in the category "educated guessing." The second question points to an unclear aspect of the paragraph quoted above that may best be elucidated by elaborating the remaining discussion of the floating relative surplus-population. Capitalist production, as noted, makes contradictory demands on population. On the one hand, increase of numbers does not meet the requirements of the accumalation of capital; hence the requirements of the accumlation of capital form the principal stimulation for natural increase of the population. This clearly contrasts with the Malthusian emphasis upon biological determinism. Any geometrical growth of population, for Marx, would not be a function of a natural law of population, but of the stimulation of capital's ever increasing rate and scale of accumulation. A corollary aspect to capitalist accumulation's stimulation of natural increase deals with the trend to maximize exploitation. Hence, the pressure is always on the laboring population to increase the rate and magnitude of the replenishment of youthful laborers. On the other hand,

$$
75^{\prime} \text { Ibid., p. } 641
$$


while pressure for increase is high, so is the existing supply of labor in the form of more expensive adult laboring populations. This contradictory condition, Marx adds, is locked into the modern division of labor which inhibits labor from moving from one branch of industry to another, due in part to specialization of the functions of labor making workers unskilled and unuseable outside their own area of competence. But there is another source of pressure stimulating natural increase beyond the above; it deals with the rapid exhaustion of labor-power. "This consumption of labour-power by capital is, besides, so rapid that the labourer, half-way through his life, has already more or less completely lived himself out." 76 This is the point where age differences by class is made significant because the life-span of the worker is so short that there is an acute need for reproduction of this supply. Marx says,

In order to conform to these circumstances, the absolute increase of this section of the proletariat must take place under conditions that shall swell their numbers, although the individual elements are used up rapidly. Hence, rapid renewal of the generations of labourers (this law does not hold for the other classes of the population). This social need is met by early marriages, a necessary consequence of the conditions in which the labourers of modern industry live, and by the premium that the exploitation of children sets on their production. 77 (Emphasized points added by this writer.)

${ }^{76}$ Tbid.

77 Ibid., pp. 641-42. Note: In this quotation, and the preceding discussion, the crux of Marx's criticism is aired, as well as Marx's alternative to Malthusian biological determinism. Marx denies that extraordinary growth must culminate in misery and that misery is the fault of the miserable. In its place, Marx places the blame squarely on capitalism. Here he adds substance to his alternative view. The problem is a social problem, and not one out of man's control, derived powerful natural laws. The proof, in part, is the fact that only the 
The second form of relative surplus-population is latent and it deals with rural-urban relationships conditioned by the nature of capitalist production and accumulation. Marx identifies the source of latent relative surplus-population in the movement of capital to control agricultural production. For reasons Marx does not elaborate, he views capital accumulation from agricultural production as continuing so long as laborers are repursed in absolute numbers in such a manner as to preclude any reattraction of them. A portion of the agricultural population is, therefore, constantly pushed into movement to urban and/or manufacturing locations to seek employment. Because this process of repulsion is ongoing, it means the flow of laborers from rural, agricultural, areas to urban and/or manufacturing areas is constantly occurring. "But the constant flow towards the towns presupposes, in the country itself, a constant latent surplus-population, the extent of which becomes evident only when its channels of outlet open to exceptional width."78 In other words, the nature of agricultural production when controlled by capitalist production repels laborers who are pressed to seek employment in urban areas. When it is recalled that capitalist industrial production tends to create relative surpluspopulation too, an unclear piece of Marx's point is clarified; the

laboring class suffers overpopulation; confirmation of a previous note, footnote 56, p. 140 of this chapter, is made here. Stimulation to increase is not biological per se, but socio-economic. Rapid growth is not a matter of mathematics, but of economics; misery and poverty are not natural, inevitable results of natural laws but are functions of economic processes.

$$
{ }^{78} \text { Marx, p. } 642 \text {. }
$$


agricultural surplus-population is latent because it cannot move to urban centers just because $1 t$ is pressed to do so, if there is no expanding capital which attracts labor. Hence, this latent surpluspopulation plays a waiting game, always watching for the opportunity to move off the countryside and into the urban, or manufacturing, center. With this clarification, it makes sense when Marx concludes his brief notation on latent relative surplus-population by stating that the agricultural laborer is constantly reduced to the minimum wages (high competition among the latent surplus-population, trapped in the countryside, for a few jobs), and therefore always standing "with one foot already in the swamp of pauperism." 79

Stagnant surplus-population forms part of the active labor army but with extremely irregular employment. This labor army is characteristically the subject of the greatest exploitation by capital because its membership is characterized by maximum working-time and minimum wages. What conditions this situation? Marx says the membership of the stagnant surplus-population is constantly recruited from decaying industries, e.g. handicrafts decaying to manufacturing, manufacturing to machine production. Hence, the stagnant relative surplus-population is that group least qualified to function in a complex division of labor. system of capitalist production. It grows in size as capitalist accumulation extends (i.e. capitalist accumulation tends to "mechanize" industries, repelling laborers, thus tending to create, to an ever increasing degree, a population largely made up of unqualified laborers).

${ }^{79}$ Ibid. 
Also (recall that capitalist accumulation contradictorily encourages

natural increase as it creates surplus-population) it forms, simultaneously, a "self-reproducing and self perpetuating element of the working-class." Marx thinks that the stagnant surplus-population forms proportionally an increasingly greater part of the general increase of the working-class; such a pattern is consistent with the tendency of capitalist accumulation to produce technical revolutions in industrial production. "In fact, not only the number of births and deaths, but the absolute size of the families stand in inverse proportion to the height of wages, and therefore to the amount of means of subsistence of which different categories of labourers dispose." 80 (Emphasized points added by this writer.)

80 Ibid., p. 643. Note: Marx treats birth and death rates, and also expresses ideas about why families are larger in the lower classes of his time; an important detail question for demography; but also a critical response to Malthus' views concerning misery. In contrast to Malthus, who regarded poverty and misery to act ultimately as checks to population increase, remember, Marx regards misery as a stimulation to population increase, which in turn further increases poverty and misery. Also, Marx's definition of misery varies with that of Malthus in that Marx does not include famine and pestilence and stresses exploitation of labor by capital via creation of long work-days, and low wage rates in his definition of misery; additional factors include unsafe, unhealthy, and generally abismal working conditions in factories and reprehensible housing. Furiher, in contrast to Malthus' principle of population, Marx cites exploitation of the working-class and capitalist accumulation's pressure for rapid increase of youthful laborers as stimulants to population growth. Thus, the lower the standard of living the greater the encouragement to population growth; on the one side from capitalist accumulation, on the other side from individual survival; in order to make enough to survive, large families were necessary among the working-class. Another reason for this pressure for large families relates to the fact that the means of subsistence could be had by the working-class only through means of employment (which favored women and children) and wages which were exchanged for subsistence. Hence, when family size is in inverse proportion to wages and the means of subsistence, the unmentioned element, means of employment, must be kept in mind. 
This stagnant relative surplus-population is the lowest form of surplus-population and finds its expression in pauperism. Marx excludes vagabonds, criminals, and prostitutes from this layer of society as he suggest three categories of paupers, (1) those able to work, (2) "orphans and pauper children," who essentially form part of the industrial reserve army, becoming active laborers in times of sudden expansion of capitalist accumulation, and (3) "the demoralized and ragged, and those unable to work," $i$.e. people unable to adapt to changes in industrial production due to the nature of the division of labor, those too old to work, victims of industry, and other handicapped members of society, e.g. the sickly, the mutilated, the blind, and so on. Marx says, "Pauperism is the hospital of the active labour-army and the dead weight of the industrial reserve army. "81 Marx regards pauperism as an inevitable and necessary consequence of capitalist production and of the capitalist development of wealth. It cannot be extricated from capitalist production, but instead of forming a burden on the shoulders of the capitalist class, pauperism is pushed onto the shoulders of the working-class and the Iower middle class.

As capitalist accumalation increases in scale, Marx emphasizes that all relations of production expand accordingly. Hence, the greater the social wealth, the functioning capital, and the extend and energy of its growth, so also the greater the absolute mass of the laboring class, the productiveness of labor, and, therefore, the greater the industrial reserve army. Now because the same forces which cause the development

$$
{ }^{81} \text { Ibid., p. } 644 .
$$


of the fowet of eapitel to accumulate also cause development of laborpower For disposai, the relative size of the industrial reserve army mast increase a the scele or accumlation increases, in fact, as the potential for experion increases, since a reserve army of labor must be on hand to zeet ang regnitude of expansion that occurs. But the greater the size of tis tacustrial reserve army relative to the active laboring population, that is, the greater the stagnant (and other forms of) surplag-pogaistion, the greater is the misery among this group. Furthex, thez paocsees point to an inverse ratio between misery and "itts toraent gi laboer." Fut another way, the less work the population does, the nore zicerabie it is. ${ }^{82}$ "The more extensive, finally, the lazarus-lavers on the rorking-class, and the industrial reserve army, the Ereater is otzicial pauperism. This is the absolute law of capitarist esceziation. ${ }^{83}$

The law of wich a constantly increasing quantity of means of production, thanks to the advance in the productiveness of socila laber, 표 be set in movement by a progressively dininisine expenditure of human power, this law, in a capitaliet aceity-winere the labourer does not employ the means of production, but the means of production employ the labourstraderzoes a complete inversion and is expressed thus: the higits tiss protuctiveness of labour, the greater is the presaze of tine labourers on the means of employment, the more precertoms, tierelore, becomes their conditions of existence, 7iz., the ande of their own labour-power for the increasing of ensther $z$ wealin, or for the self-expansion of capital. The Pact titat ite 3 eans oi production, and the productiveness of labort, increase Iiore rapidly than the productive population,

Q2 ware boe not mean to inply that employment is not miserable; in iactit 1a, but the misery of employment is superceded by the miserp $0:$ ztaznetion in onemployment.

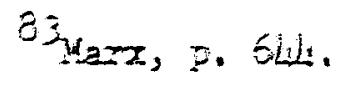


expresses itself, therefore, capitalistically in the inverse form that the labouring population always increases more rapidly than the ccnditions under which capital can employ this increase for its own self-expansion. 84

Marx drives deeper on this theme, elaborating still further the relation of misery to capitalist accumulation and surplus-population. He reiterates that exploitation incraases with accumlation of capital, that the press of the capitalist is always to squeeze more surplus-value from production, ultimately always at the expense of the individual

laborer. Marx says,

But all methods for the production of surplus-value are at the same time methods of accumulation; and every extension of accumulation becomes again a means for the development of those methods. It follows therefore that in proportion as capital accumulates, the lot of the labourer, be his payment high or low, must grow worse. The law, finally, that always equilibrates the relative surplus-population, or industrial reserve army to the extent and energy of accumulation, this rivets the labourer to capital more firmly than the wedges of Vulcan did Prometheus to the rock. It establishes an accumlation of misery, corresponding to the accumulation of capital. Accumulation of wealth at one pole is, therefore, at the same time accumulation of misery, agony of toil, slavery, ignorance, brutality, mental degradation, at the opposite pole, i.e., on the side of the class that produces its own product in the form of capital. 85

Marx notes that there has been two views of wealth and misery

${ }^{84}$ Tbid., pp. $644-45$.

${ }^{85}$ Ibid., p. 645. Note: In this stroke Marx completes his argument against the Malthusian view of misery. Misery, as the Malthusians contend, will not check population growth and is not inevitable. It is a function of capitalist production and grows as capital grows. Indeed, instead of checking population growth, it fosters it (among the laboring class). Indeed, perpetuation of capitalism compels perpetuation of hunger and misery (p. 646) and hence gives the appearance, and only the appearance, of a principle of population operating. 
persisting. On the one hand, his view, expressed well by the 18 th century monk Ortes. 86 Wealth, abundance, cannot exist without it causing want of others. Riches for a few means deprivations for many. The wealth of a nation corresponds to its population size, and misery corresponds to wealth. The poor and idle are a necessary consequence of the rich and active. On the other hand, "In a thoroughly brutal way about 10 years after Ortes, the church of England parson, Townsend, glorified misery as a necessary condition of wealth." 87 Marx notes Townsend's reactions were attempts to deny the poor relief ${ }^{88}$ and castigates him for such a reaction. He then suggests that the great bourgeois efforts to lock the working-class into a miserable condition are manifestations of underlying class struggle. In fact, the capitalist finds in such degradation of the masses a security for his wealth. But the reality of science and industry advancing is that every laborer can produce more than he needs or wants. Consequently, there is no need for such miserable and degraded conditions. They serve only to enhance the life of a few at the expense of the masses. In his conclusion Marx implies that revolution to socialism would eradicate the conditions that had produced overpopulation and misery among the laboring class.

${ }^{86}$ Recall that Ortes' population thought was a significant anticipation of Malthus, yet Marx considers him a predecessor of himself. This is important in the next chapter.

87 Marx, p. 646.

${ }^{88}$ At this junction, in a footnote, Marx reiterates his criticism of Malthus as an apologist, but more significantly, accuses him of being nothing more than a plagarist of Townsend and Steuart. Toid., p. $647 \mathrm{n}$. 


\section{SUMMARY}

Based upon a reasoning system that emphasizes social problems and excludes nature as significant combined with a view that stresses conflict, Marx looks into the question of population within the context of a mach larger inquiry into the nature of capitalism. In his look into population he more or less takes an opposing position to that of Malthus considering population problems to be derived from economic activities and not from biological determinism. He considers Malthus' thrust ultimately to be an apology for the capitalist class and a plagarism of other writers of his time. However powerful his criticism of Malthus, Marx's articulation of thought on population cannot be considered a theory of population; indeed, its articulation is often unclear and ambiguous, leaving more questions than it answers. These anomalies need considering, and that shall be the principal purpose of the next chapter. Accordingly, further summation may best be deferred to the beginning of Chapter $V$ for it will serve as a useful foundation for a critical look into Marx's thought, his reaction to Malthus, and their places in the sweep of the history of demographic thought. 


\section{CHAPTER V}

\section{A NEW PERSPECTIVE ON MARX'S POPULATION THOUGHT}

Modern Marxists believe Marx's population thought was a strong criticism of Malthus and the basis for an alternative theory of population to that of the West (which they consider evolved from Malthus). By comparing Marx to Malthus, some anomalies will appear which will give reason for doubting modern Marxist beliefs. By, thereafter, integrating Marx into the sweep of demographic history, a new perspective on Marx will emerge which will compel re-evaluation of typical views concerning Marx on population.

\section{COMPARISON OF MARX AND MALTHUS}

Most often Marx is placed at odds with Malthus. Marx made explicitly clear that he objected to Malthus because Malthus was (1) a parson, (2) a plagarist, and (3) an apologist for the capitalist class. Also, Marx rejected the Malthusian position because (1) biological determinism (the setting of natural law as an independent variable dominating man) as a basis for the principle of population was fallacious; (2) there was no universality to the natural law of population; (3) overpopulation was not inexorable; (4) poverty was not the fault of the poor; and (5) the existence of misery was not (a) natural or necessary and (b) a check to population growth. With these simple contrasts to Malthus, it would be correct to conclude that Marx was 
anti-Malthus. However, a closer examination reveals more to the interplay between Marx and Malthus, and to Marx's population thought, than simple comparisons reveal.

The differences between Marx and Malthus have been emphasized at the expense of similarities between them. Also, there has been a failure to recognize that differences and similarities cut into more than just a simple debate about the nature of overpopulation. To confine analysis to this point would be to miss the more substantial differences and similarities hidden from casual glances. Indeed, the issue of overpopulation is not the crux of the matter; the social and economic problem of poverty is the crux of the matter, heavily accented by certain empirical questions gemaine to demography proper. Finally, certain philosophical differences between them exist. Thus, a thorough comparison requires giving attention to the economic question of poverty, the economic-demographic question of overpopulation, some more technical empirical demographic questions, and philosophical questions. For organizational and logical efficiency, it is best to begin with philosophical similarities and differences.

\section{Philosophical Similarities and Differences}

Both Marx and Malthus were in favor of progress; progress as conceived in the 18 th century as toward the infinite perfectibility of man. However, they differed concerning the form that such progress should take. On the one hand, Malthus favored progress that was evolutionary development of the status quo. He ultimately had a hope for the perfection of man and emphasized the role of population control in achieving that end. On the other hand, Marx favored progress that 
was revolutionary, that transformed the status quo. He conceptualized social progress as a revolutionary movement through ever higher stages, toward ever greater perfection of man.

Both had corrolary pro-utilitarian views; simultaneously differing on this point as well. Malthus' utilitarian dream was anti-revolutionary. He regarded the greatest happiness to be gained from a society which perpetuated the status quo; chief among the elements to be preserved being private property and private enterprise. Even though such iniquities as inequality persisted in existing societies, revolutionary change only caused greater misery than already existed. It was better to improve upon the status quo (and admit some things were inevitable, like inequality) because revolutions invariably replaced tyranny with worse tyranny. Marx's utilitarian dream was revolutionary. Human improvement and the greatest happiness was achieved through conscious recognition of tyranny, misery, and exploitation and its subsequent overthrow and eradication; with a principal change being the erasure of private property to help create full equality. Indeed, revolutionary change was a necessary consequence of the struggle, conflict, contradictions internally generated in the womb of the old society. Thus, the greatest happiness could not be achieved by perpetuating the status quo. To claim revolution would cause greater tyranny than existed was invalid when the claims came from the tyrants themselves (in this case, Marx assumed Malthus to be a tyrannical character); furthermore, it denied the truth of the inevitable and necessary trend in the historical development of human society. Both agreed that man was rational; but the consequences of man's 
use of rationality were viewed differently. Malthus thought man, being rational, could recognize inexorable limits to population growth, that continued growth caused poverty, and misery, and that man could come to control it rather than fall prey to the horror of overpopulation. Reason, therefore, for Malthus, extended to the individual and the femily; responsibility was placed upon the shoulders of the individual for controlling population growth.' Marx thought man, being rational, could use his intellectuai capabilities to indefinitely extend and improve his productive powers thus making the need for population controls irrelevant and unnecessary. Reason, for Marx, did not come to rest upon the shoulders of the individual placing responsibility for problems in his hands, but was contained in the history, the life of men, and the nation; dialectical materialism and historical materialism compelled higher reasoning to rise to the occasion as the stages in the ristorical development of human society unfolded.

Both Marx and Malthus focused upon struggle; however, for Malthus struggle was struggle for existence, a battle between man for produce of nature; for Marx straggle was class struggle, the struggle between different groups of men for the productive forces and the produce of society; the struggle for existence was the class struggle for control of productive forces of society.

Some other contrasts include the following: Malthus focused on the individual, Marx stressed the class as the theoretical referent. 2

${ }^{1}$ Petersen, Op.Cit., pp. 80-81.

2Ibid., p. 81. Note: Indeed, Marx's criticism of Malthus is largely that he takes a class position on the question of poverty and 
Malthus regarded man as in nature, as inextricably subject to nature's laws, Marx regarded man as increasingly outside nature, as liberating himself through production, capable of ever increasing control over nature because of it. While both regarded man as a special animal, different from all others, Malthus saw the specialness as spiritual, Marx saw it as materialistic, the result of history and productive power. Malthus saw the earth as ultimately a finite space; Marx regarded it as an infinite world. Malthus considered man regulated by unconscious processes he could control only in limited degrees; Marx saw consciousness, the increasing ability to control nature as man willed. Malthus regarded the future to be no different from the present while Marx regarded the future to be bright.

Economic Similarities and Differences ${ }^{3}$

The principal economic question on population for Marx and Malthus was the problem of the cause of poverty. Malthus emphasized biological determinism; Marx, socioeconomic conditions of capitalism. More specifically, Malthus defined the problem of poverty in terms of the principle of population acting unconsciously, inexorably, as a natural law, upon the poor who overbred, ${ }^{4} i . e_{\text {. population was an independent }}$

misery, and attempts to excuse the criminal behavior of what he knows to be the cause of ills-the capitalist class.

${ }^{3}$ Marx and Malthus have similarities and differences over economic principles beyond those related to population. They do not pertain to this study, however, and hence were excluded from consideration.

4 It mast be assumed socioeconomic factors are not operative here to check growth, as Malthus discussed in works other than his essays on population. If the poor had an increasing standard of living, or 
variable, resulting in economic hardship and increasing misery for the poor as a class and for society as a whole because it conditioned wars, disease, pestilence, and vice, which in turn acted to check further increases in population. Marx defined the problem of poverty as a conscious class problem; misery being the result of economic forces in action encouraging, not checking, further population increases, hence further increases in misery. Population, then, was not an independent variable, but a dependent variable affected by the normal operation of capitalist production.

Malthus and Marx differ on the definition of misery also; Malthus considered it famine, pestilence, disease, vice, i.e. misery amounted to a rubric for a multitude of iniquities; Marx considered misery to be exploitation, disease caused by exploitation, the ruin of bodies by horrible living conditions, and general working conditions of capitalist production. By implication, Marx would consider starvation, disease, pestilence as forms of misery if conditioned by capitalist production. Within the large question of the cause of poverty, a more specific contrast appears. Both agreed upon a theory of increasing misery. However, Malthus' theory of increasing misery was tied to the idea that ultimately, as misery increased, population growth would be checked. Without misery perpetually checking population growth (assuming moral restraint being either not employed or not effective) misery would

something to fear losing, this matter of increasing misery would not be operating. Thus, what is assumed under the above conditions is a circumstance. where the means of subsistence have not been secured, the only condition where the socioeconomic checks would not be operating as intermediate checks. 
increased all the more. 5 Marx's theory of increasing misery was linked to capitalist accumulation and had no explicit and strong emphasis upon checks. Misery increased as the scale of capitalist accumulation and exploitation increased. The greater the misery, the greater the stimulation to population increase. If Marx's view is looked at as implying that increased standard of living would check population growth if misery stimulated it, then within the differences concerning the theory of increasing misery, Marx and Malthus appear to have a fundamental point of agreement; for Malthus too saw standard of living as a check to increased population growth.

From the above it appears that poverty, as a condition, was seen differently by Marx and Malthus. Poverty, for Malthus, was necessary, inevitable, permanent (if rational control of growth via moral restraint were not invoked); i.e. poverty was permanent, but not the miserable form of it born of overpopulation. Poverty, for Marx, was also necessary and inevitable under capitalism, but was not permanent; instead it was a transitory phenomenon, a consequence of capitalism; and capitalism was one stage in the historical evolution of society destined to dissolve.

As for the solution to the problem, Malthus proposed to solve the problem through control of population increase via moral restraint,

${ }^{5}$ An assumption must be made here: that subsistence had not been secured, that socioeconomic intermediate checks were not operating to check growth. If Malthus' total theory of population is looked at, under circumstances where intermediate checks were not functioning, the issue of increasing misery, for Malthus, would not appear. For Marx, under capitalism, increasing misery was an inevitable consequence of the normal operation of the industrial cycle of capitalist production. 
through creating a healthy economy with growing industrialization and strong effectual demand for labor. For Marx, the solution was revolution, eradication of capitalism, institutionalization of socialism; 6 merely controlling population size would not change the cause of poverty. Indeed, under capitalism, a controlled population size was not desirable because the industrial reserve army always needed to be larger. However, this writer thinks Marx would agree with Malthus that industrialization and effectual demand for labor could influence growth by raising the standard of living of the poor. To do so, wealth would have to be equitably distributed and ownership of the means of production shifted to the hands of the laboring class. Accordingly, Industrialization and effectual demand for labor under capitalism, this witer thinks Marx would argue, only perpetuated conditions which created poverty; i.e. the normal operation of capitalist production. This point can be carried one step further. If it is accepted that Karx implied the raising of the standard of living of the poor could discourage population increase an interesting contrast between Marx and Malthus emerges. "Moral restraint" for Malthus was the theoretical equivalent of economically derived restraint in Marx. Both writers postulated "restraint." Strictly speaking, economic restraint is a form of moral restraint because it is restraint, if such is possible, of the indefinitely extensible wants of humans as postulated by Veblen.?

6etersen, pp. 78-79.

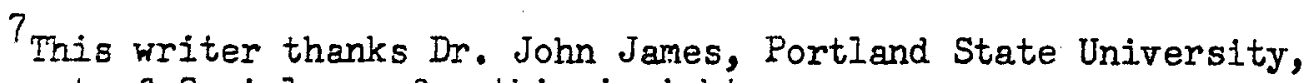
Department of Sociology, for this insight. 
Economic and Demographic Questions of Overpopulation

The problem of overpopulation appears as another issue which derives from concern with the question of poverty. To deal with it, the matter of overpopulation, and examination of socioeconomic checks to population increase, must be considered.

Overpopulation was demographic for Malthus, economic for Marx. Malthus discussed population growth, and factors affecting it, considering the prime consequence of continual growth overpopulation; where overpopulation was an excess of mouths over available food supply, or an absolute over-supply of people. Marx discussed population growth, and factors affecting it, strictly in terms of a larger economic concern with capitalism, holding the view that the prime consequence for the laboring population of its operation was apparent overpopulation; where overpopulation was a relative excess of numbers conditioned by the normal operation of capitalist production, in particular, the pattern of capitalist accumalation.

The apparent overpopulation was called, by Marx, the industrial reserve army; again, the result of capitalist accumulation. Malthus did not specifically state the existence of an industrial reserve army, but it appears he did recognize its existence.

A major difference between Marx and Malthus appears concerning the question of limits to population growth. Absolute overpopulation occurred because natural limits to population growth existed, in Malthus' view; overpopulation was relative because no limits to growth existed under proper modes of production, in Marx's view. A central issue in this difference between Marx and Malthus is the question of 
land. For Malthus, a major limitation to population growth was availability of land on the one hand, and its productiveness on the other. These two factors together constituted Malthus' concept of diminishing returns. First, land is limited. Hence, at some point, if growth continues, there will be no more land available; at which point food supply reaches ultimate limits. However, when land is looked at, it is apparent that there are other limits; not all soil is equally fertile (also there is implied the notion that productivity of the soil can be improved through external supports like fertilizer only slightly). As a result, as the best soils are used up, i.e. put into use and eventually used up (for in Malthus' time soil husbandry was not an accomplished science and soil fertility did decline), less fertile soils must be put into production, with crop yields consequently diminishing. Thus, if growth continues, it is faced with absolute limits of land, on the one hand, and diminishing returns to land on the other.

For Marx, land was not a limit because of the ability to constantly improve output on existing land. Clearly, at base was a debate over the principle of diminishing returns. Marx could not merely argue that land was not a problem though fixed in absolute quantity without simultaneously denying the validity of the principle of diminishing returns. He had to do both for his whole argument to hold water; for if Marx admitted land was a limitation, he could not argue for the indefinite extensibility of population growth or of social growth in general. Marx took the position that the principle of diminishing returns was fallacious on philosophical as well as economic grounds. He argued that absolute fertility of all grades of soil could 
be constantly increased. He turned to Darwin for partial proof (in addition to his embracing of the view that man's reason, through science, would make constant improvements possible) by noting that Darwin discovered the "geometrical" progression of animal and plant life, thereby overturning Malthus' claimed arithemetical limits to the rate of increase of food vis-a-vis the geometrical growth of human population. ${ }^{8}$

A related concern appears in Malthus' conclusion that the means of subsistence did not vary significantly, but were relatively fixed within a country while Marx concluded that the means of subsistence (and the means of employment) were not fixed but varied significantly with the industrial cycle, stage of capitalist accumulation, magnitude of accumulation, and relations in the organic composition of capital; and presumably with the stage in the historical development of human society as well. A question arises here concerning variations in meaning of the term "means of subsistence" between Marx and Malthus. To Malthus, "means of subsistence" was more or less synonymous with food supply and ability to produce it; to Marx, the term meant "means of employment" at a casual glance. But beneath the surface Marx's meaning is less evident. For Marx, the means of subsistence were the means of employment for the laboring class while for the capitalist class, which he did not explicitly discuss, means of subsistence were ownership of production and the products of production. Now looking at Marx's debate with Malthus over diminishing returns, this writer concludes that ultimately, both agreed on the meaning of the term "means of subsistence; " namely, food supply

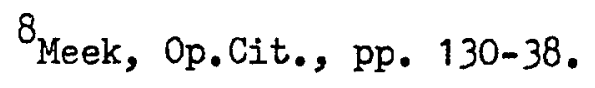


and the ability to produce it. Probably, Marx's emphasis on means of employment applies for the laboring class under the capitalist stage of production. (It is unfortunate he did not extend his discussion to socialist production to clarify some of the hazy areas.) If attention is devoted to the different emphasis between Marx and Malthus over whether increase in production could be indefinitely extended, the possibility of confusing aspects of variations in meaning of the term "means of subsistence" will be reduced.

While both ultimately agreed on the meaning of means of subsistence, and disagreed concerning the extensibility of production, both considered technology as capable of extending productivity; ${ }^{9}$ Malthus saw increased productivity as possible but ultimately limited by diminishing returns and inability to keep pace with the rate of growth of population. (It might be suggested that under industrially viable conditions, rate of growth of population is kept below rate of increase of subsistence, following Malthus' discussion of industrialization and population, and hence increased productivity could continue; but under the auspices of diminishing returns, a point would be reached where industrial viability declined, and with it would go the viability of intermediate checks, and with it would come increases in the rate of population increase.) Marx saw production as indefinitely extensible, at a faster pace than the increase of population, under appropriate means of production, because each man could produce more than he himself needed.

$$
{ }^{9} \text { Davis, Op.Cit., p. } 550 .
$$


Thus, within the web of disputes over the question of overpopulation, some important similarities appear. First, ultimately, Marx and Malthus appear to agree on the meaning of the term "means of subsistence." Second, technology could extend productivity.

\section{Similarities and Differences On Demographic Questions}

The discussion of empirical demographic questions by Marx and Malthus is usually overlooked. It is this area of comparison, in particular, which raises some questions that, in turn, invites development of a new perspective on Marx.

Marx and Malthus treated such demographic questions as, where does population come from, i.e. what causes growth? Does overpopulation necessarily occur, and if so, under what conditions? Are there checks to population growth? What is the relation of population growth to food supply? What can be done to ameliorate troubles from population growth? Now many of these questions have been observed as influencing discussion in previous sections. However, previous discussions can be still more carefully considered for specific points of comparison which reveal some interesting interplays, comparisons, concerning what stimulates population increase, demographic questions related to this question, and some socioeconomic influences on increase.

A basic difference exists between Marx and Malthus regarding the cause of the stimulation of population increase. Malthus' position on the issue is more complex than Marx's. On the surface, Malthus postulated increase to be innate, i.e. the passion between the sexes is necessary and will remain nearly in its present state. However, looking at his total population theory, assuming availability of food 
supply, innate sexual drives were checked by socioeconomic factors; namely, effectual demand for labor, the development of industry and standard of living, with a consequence being institutionalization of preventive checks such as habits of productivity, the promise of upward class mobility, habits of consumption, the creation of wants, and efficiency of resource use. In contrast, Marx argued that reproductive behavior was strongly influenced by socioeconomic conditions. However, Marx did not say whether he accepted or rejected the premise that the ultimate cause of growth rested in an innate passion between the sexes. This point is a significant question concerning Marx's position. It needs some further discussion.

First, in all his work Marx conspicuously neglects to treat this point. Yet on more than one occasion he does make reference to "instincts of propagation." Now Engels, in his letter to Kautsky, seems to agree for he used the term "instinct for reproduction." Nevertheless, it remains unclear whether these terms were intended to be read as literal or metaphorical expressions. Second, adding to the problem, is this point: there is a difference between "instincts for propagation" or an "instinct for reproduction" and an "instinct for sex relations." It seems clear that Malthus was referring to the latter. It may be the case Marx also intended the latter (for it has been a philosophical and biological term to conform to Puritan ethics used particularly by 18 th century scholars). Both Marx and Malthus recognized that sex relations, without children resulting, occurred among the capitalist class. 10

10 This writer thanks Dr. Charles Bolton, Portland State University, Department of Sociology, for this important distinction and insight. 
Now, if Marx is taken literally, and its is assumed his meaning was "instinct for reproduction" instead of "instinct for sex relations," Marx is at odds with Malthus, who seems clearly to intend "passion between the sexes" to mean "instinct for sex relations." It also means that this notion does not square with his economic interpretation of population increase. If Marx is taken to mean "instinct for sex relations" when he says "instinct for propagation" then Marx and Malthus agree that there is an innate drive stimlating natural increase. Furthermore, both agree that industrialization, and a series of intermediate checks can affect reproductive behavior. Still further, it points to a similarity which must operate to prevent Marx from falling into gross inconsistency by positing instinct as operative while interpreting population increase as an economic phenomenon. This similarity is that both writers assume, or take for granted, subsistence has been secured. Notice that neither Marx nor Malthus discusses the nature of social life and reproductive behavior at the level of barebones subsistence; all Malthus says is that famine is more or less an ultimate check which appears only if others have failed; Marx seems to give no attention to this matter. Consequently, it is important to note that both seem to separate discussion of population processes into two arenas, one is the conditions at the bare-bones level of subsistence (which neither really considers) and the other is processes operating with food supply largerly secured.

These factors ieveal one other important characteristic. Typically, Marx is considered as making very general, sweeping challenges of Malthus; that Marx's reaction to Malthus was a denial of 
the entire Malthusian position. However, from a careful study of similarities and differences, it appears that (1) there is substantial agreement over many principles regarding population and (2) as a result, the points of disagreement are quite specific matters of detail. So far as this writer is aware, this observation has not been made before. It invites a new perspective on Marx which will be developed shortly. While some uncertainty about similarities and differences over the question of the cause of increase persists, the issue of increase itself is further treated in discussion of why high rates of increase appear. Malthus argued from his apriori postulates that natural increase was geometrical; hence high rates of increase were merely the consequence of the "geometry of population" (here assuming checks, of all types, being inoperative, or for some reason, ineffectively operative). Marx, in contrast, argied that high rates of increase had socioeconomic causes. First, capitalist accumalation demanded a large youthful laboring population. Second, the nature of industrial production and capitalist exploitation resulted in a very high death rate and a very short lifespan for laborers, thus making rapid reproduction of the mass of living labor essential (a socially caused necessity). However, this writer was not able to find a statement anywhere in Marx's work where Marx rejected the principle of geometrical growth of population postulated by Malthus. In fact, Marx's criticism was not over this point; it was with Malthus' view that food supply could only increase arithemetically. Marx implicitly argued production could be geometrical too; hence, it appears that Marx essentially agreed with Malthus that population growth had a geometrical rate of increase to it. 11 
From the above, a striking comparison emerges. Malthus placed emphasis squarely upon birth rates to account for potential for rapid population increase. Marx implicitly recognized the importance of birth rates, but appears to emphasize the role of death rates (coupled with socioeconomic forces demanding increased numbers of the laboring class) as the factor stimulating population increases.

On close examination of comparisons between Marx and Malthus on the question of checks to population growth, it appears that Marx saw population as adapting to economic conditions while Malthus saw population as checked by natural conditions and socioeconomic conditions. In other words, Marx looked at population as a social adjustment to forces of and relations of production while Malthus emphasized, ultimately, checks as external, natural law, forces acting upon man; i.e., population naturally adjusted to conditions. Another aspect of Marx's emphasis on adaptation verses Malthus' emphasis on checks appears with the question of early marriage. Malthus explained early marriage as a function of England encouraging it by the poor laws. No discouragement to increase existed, no reason to avoid marriage at an early age existed with the poor laws as a

${ }^{11}$ Implied in Marx is the conclusion that population would stop growing if unneeded, i.e. that geometrical growth was not necessarily the case. This follows from Marx's placing population as a dependent variable of production; thus, if production did not grow, the stimulation to population increase would be removed. Under capitalism, this eventually would not occur because capitalist accumulation compelled population increases to always continue. Malthus, too, found circumstances where geometrical growth was not necessary, namely, where effectual demand for labor and industrialization were viable, healthy; although with Malthus, this view was explicitly stated while it had to be inferred in Marx. 
shelter. Hence, the passion between the sexes being what it was, early marriage occurred, contributing to population increase. Marx saw early marriage as an adaptation to the dictatorial needs of capitalist accumulation, on the one hand, and survival of the laboring population (threatened as it was by the short Iife-span of the individual worker laboring in miserable conditions) on the other hand.

A significant similarity which appears in this discussion is the recognition that both Marx and Maltisus discussed consequences of population among the poor classes; neither considered directly conditions affecting the upper classes.

Another similarity appears amid the above differences. Marx regarded standard of living, by implication, as a check to population growth, i.e. the higher the standard of living the less stimulation to increase existed. Malthus also considered standard of living to be a strong check, discouraging the formation of families. How interesting that both agreed on the role of standard of living $!^{12}$

A final area of comparison appears in contributions each made to demographic thought. If nothing else, Malthus did significantly contribute to establishing empirical data, and statistical techniques, as important features of demographic analysis. Kammeyer even goes so far as to assert that Malthus brought empirical science into population

${ }^{12}$ This writer intended to imply Marx did not emphasize checks in the manner of Malthus, not that Marx did not notice checks. While mostly implicitly stated, Marx did identify checks. Above, the intention was to point out that Marx's emphasis appears to suggest Marx's checks amount to social adaptations, in keeping with his emphasis on population as a dependent variable, in contrast to Malthus' checks which appear to be, analogically, more like roadblocks populations cannot escape, in keeping with his emphasis on population as an independent variable. 
study. ${ }^{13}$ However, a look at the history of demographic thought finds Graunt, Petty, Conring, Sussmilch, and others deserving of such kudos before Malthus. More appropriately, Malthus may be viewed as contributing to the development of a set method of inquiry for demography, i.e. of helping to standardize, institutionalize a study of ponulation. This writer thinks Marx merits looksng at in the same way, a view not previously advanced (and it will require development of a new perspective to justify this writer's view of Marx). At this point, it is sufficient to note that Marx was making an effort to point to some areas in which empirical inquiry needed developing. Marx made an attempt to (1) explain the discrepancy in the sex ratios of populations favoring females; (2) explain differences in family size from class-toclass; and (3) explain life-span differences between classes; i.e. (2) and (3) imply inter-class analysis by emphasis on conditions in the laboring class explicitly studied by Marx. All three points were advanced, based on empirical data and suggested, this writer thinks, by implication, that further inquiry was needed into these points. It may, therefore, be said that Malthus and Marx were, in this respect, complements, both attempting to contribute to the body of demographic fact and theory which had been developing for some time before either wrote.

Thus, Marx and Malthus appear as both antagonists and as complements on close examination. There are overlaps and divergences in areas of philosophical foundation assumptions, economic theory and the

$$
13 \text { Kammeyer, Op.Cit., p. } 5 .
$$


social problem of poverty, economic and demographic concerns of overpopulation, and some more strictly empirical demographic questions. Some principal similarities of surprise included (1) both identifying an industrial reserve army, (2) both postulating geometrical growth to population, although Malthus' postulation was a strong explicit statement, while Marx's postulation must be considered, despite the fact it is clearly evident, an implicit statement, (3) both postulating innate psssion between the sexes, (4) both agreeing, ultimately, upon the definition of means of subsistence, (5) both noting the significant place of socioeconomic checks on population, and (6) both contributing to the broad development of demographic science. As a result, disagreements initially presumed to be broad, general, dichotomies turn out to be quite specific disagreements concerning one or another detail related to a particular aspect of the question of population. By comparing Marx and Malthus some questions arose concerning what Marx really thought about population. These questions essentially appear as anomalies, or puzzles, regarding Marx's intended meaning and purpose. To resolve the confusion predicated upon these anomalies, a new perspective on Marx will be advanced. However, before developing this new perspective, it will be beneficial to compile anomalies in Marx's thought as a basis for launching the new perspective.

\section{ANOMALIES IN MARX}

In this section anomalies in Marx will be compiled, after which will follow (a) questions concerning Marx's criticism of Malthus and his possible intentions in criticizing Malthus, (b) questions about 
whether Marx was writing a theory of population, and (c) questions concerning some background assumptions arising from the second question, (b).

Anomalies Noted in Comparison of Marx and Malthus

Some questions arose from comparison of Marx and Malthus. (1) Why did Marx fail to criticize directly Malthus' postulate that stimulation to growth was innate? (2) What is the significance of finding Marx and Malthus agreeing on so many points concerning the question of population? (3) What significance is there to realizing points of dispute seem more specific than general? (4) Why did Marx, if he so vehemently rejected Malthus (as the often vitriolic quality of his comments on Malthus indicates) fail to criticize him more systematically, fail to completely criticize him, fail to articulate a clear alternative theory of population? Why did Marx leave such anomalies as the above?

A related question which comes from reading Marx is, why did Marx fail to elaborate on population thought before Malthus except in the most casual and most brief manner? Dare it be suggested that Marx's rejection of Malthus was not a rejection of population thought preceding him upon which he based his thought? Dare it be suggested that Malthusianism for Marx was much more specially defined than was and is generally thought?

Further Anomalies

Anomalies of more complexity appear by looking more carefuliy at Marx's more or less unsystematic criticism of Malthus and his juxtaposition to Malthusianism. If Marx was out to attack Malthus per se, 
why did he stop where he did? It could be said that Marx stopped where he did because he had identified the major points and attacked them to his satisfaction. The fact is, however, that Marx's major criticisms of Malthus amount to challenges to the person more than the structure of the thought of the person; recall Marx accused him of plagarism, of poor scholarship, of being a slanderous accuser of and parasite (sycophant) of the ruling class. These are hardly substantive criticisms of the principle of population; instead they are criticisms of the use of knowledge, theory, science. While it cannot be denied that Marx failed to make substantive criticisms, it was seen in Chapter IV that substantive points for the most part were not specifically directed at Malthus or the principle of population. Hence, the question does seem worth asking: why did Marx stop where he did? or, why not a more systematic criticism of Malthus? Another possible answer might be that Marx's criticism was written in context of a discussion of the matter of the general law of capitalist accumulation. His venture into criticism of Malthus was made, therefore, parenthetically, i.e. only insofar as the boundaries of his central idea, his subject, would permit. While this might be valid for Chapter XXV of the first volume of Capital, or even for Capital as a whole, it is not a legitimate rationalization for all of Marx's works, especially considering the importance he admitted to advancing criticism of Malthus (see footnote 4 , Ch. IV). Nevertheless, in all places where Marx made criticism of: Malthus, e.g. Theories of Surplus Value, or where Engels made criticism, e.g. Dialectics of Nature, the same, almost casual, pattern persists. In some place among the complete works of Marx and Engels, a proper 
forum existed, or could have been created, for a strong systematic criticism of Malthus' theory of population; this may especially be true for Dialectics of Nature. Yet nowhere is there a systematic criticism offered. Why? A new perspective on Marx may help explain this incongruity。

Some other questions arise concerning Marx's criticism of Malthusians, or perhaps more appropriately, pre-Malthusians. Just what did Marx intend by criticizing Malthusians as he did? An aspect of Marx's criticism of Malthus is that Malthus plagarized the writings of other parsons; e.g. Townsend, Tucker, Wallace, Chalmers, and Brückner. Marx also noted that analysis of population was far more the purview of political, economic, and social thinkers whose views were not tainted by religion; namely, a tradition spanning the 18 th century including such Iuminaries as Quesnay, Mirabeau, Steuart, Hume, Hobbes, Locke, Law, Ortes, and others. ${ }^{14}$ Marx correctly notes that Malthus, for the most part, gave no credit to this backlog of luminary thought. Now looking at Marx, it becomes evident from the above listing, and from a perusal of footnotes and bibliographies of Capital (all three volumes) that Marx was well versed in the works of the 18 th century (and all scholarly writings dating from the Greeks) thinkers, although he seems more familiar with the writers of England and France than of Germany, perhaps because German thought was so much the same through most of the 18th century. When Marx's footnotes and bibliographies are examined, it

14 Marx, p. 616n. Note: Marx's criticism of pre-Malthusians were of parsons writing on population. His own population thought does not mention Malthusians; evidently his thought was not a criticism of them per se. Also, many pre-Malthusians were also pre-Marxists . 
becomes clear that Marx was familiar with almost all precursors of Malthus. Yet Marx's criticism of Malthus and Malthusians, or preMalthusians, is confined to a select group of mostly English parsons. Does this mean that, at base Marx accepted the population thought of precursors of Malthus who were not parsons? Since he did explicitly criticize parsons but did not explicitly criticize all those who anticipated Malthus significantly, does it mean that Marx's notion of "Malthusian" is more limited than has been assumed (particularly by modern Marxists), i.e. confined to parsonial expressions (and perhaps writers who used population as an apology for the excesses of capitalism) $?^{15}$

Clearly, this failure to be more specific and explicit about intended meaning is an irksome problem with Marx which gives rise to some curious anomalies. The anomaly above is especially curious when

15 This writer has intended to use the terms "pre-Malthusian" and "Malthusian" interchangeably to mean either a general perspective which regards population a problem needing control to be solved or more specifically as a reference to a select group of writers who were parsons and/or apologists for capitalism. The modern Marxists use the term in an even more general sense than as a general perspective which sees population as a problem, i.e. as a rubric for Western population thought (and possibly any thought not modern Marxist), rationalizing such usage as relective of Marx's intended meanings. At issue is this questions. How did Marx mean the term "Malthusian?" If he intended it in a more specific way than has been thought by modern Marxists, it is inappropriate to see it used as a broad general rubric.

Further, the term "Malthusian" was introduced because there is a 50 year span between the.time of Malthus and Marx. So when Marx wrote, Malthusian, and pre-Malthusian, thought had to be dealt with. However, based on footnotes and bibliographies, it appears that Marx did not consider writings in the 50 year span as significant as those of the 18 th century because relative to his references from the 18 th century, the 19th century writers cited are few. This writer concludes that for Marx, the historical sweep was of greater. importance than a short timespan; not surprising considering Marx's reasoning system, especially the historical materialist component. 
it is realized that Marx considered the significant precursor of Malthus, Ortes, to be "one of the great economic writers of the 18 th century." 16 While it is troublesome to ponder anomalies arising from Marx's criticism of Malthus, it is all the more troublesome to ponder Marx's thought itself. After examining Marx's thought carefully, the question arises, was Marx's thought intended as a theory of population? If Marx was writing a theory of population, and intended it as such, why did he fail to elaborate it systematically, as a principal focus in his critical look at capitalism, with the same degree of rigor as found in the general examination of capitalism? Since he argued population processes were time-bound to a particular stage of economic development, why did he not elaborate theories of population for the feudal stage, or other stages of the development of production in man's history? In particular, why did he fail to elaborate a theory of population for the claimed-to-be emerging stage of production-socialism?

Further, in the structure of Marx's argument, he did not explicitly criticize some basic foundation assumptions advanced by Malthus on why population grows. By not doing so, is Marx implicitly accepting their validity? As previously noted, Marx appears to agree with Malthus that population grows geometrically, that an instinct for sex relations is the ultimate basis of growth, and that there is viability to population-food supply relations (not denying the relationship per se, only...) denying food as a check because (1) man has the potential for producing food as fast as population grows given the proper modes and relations

$$
16 \text { Marx, p. } 646 .
$$


of production, and (2) in capitalist production, the means of employment intervenes between laborers and production of subsistence. Accordingly, it does not seem unjustified to ask the question, is Marx implicitly accepting some points advanced by Malthus as valid? Or, perhaps, was Marx really opposed just to Malthus and parsons and not to the structure of population thought which had developed before Malthus?

Regardless of whether Marx was writing a theory of population, a major background assumption in the structure of his reasoning, and in the work of Malthus, which gives cause for question concerns the principle of natural law. Recall, for Malthus, the principle of population was a natural law; a universal and necessary truth in the same manner as Newton's physical laws which bound man eternally to the ultimate dictates of nature. Such a line runs counter to the dialectical materialist and historical materialist focus of Marx. If man is bound to society and is marked as different from the rest of life by the ability to produce and the existence of history, then to claim man is universally, necessarily, eternally bound by a natural law is unacceptable. As noted, Marx was compelled to criticize the concept of natural law. Out of this criticism emerges some additional anomalies. Marx's position does not entirely deny natural law. It regards it as operating in the unconscious world. Since man is conscious, and rational, he can see and know natural laws, and essentially, through production (and economic development), circumvent them, or control them. In their place, or superseding them, emerge socioeconomic and historical laws specific to a particular historical stage in the development of society. Some confusion over the conception arises, though, because 
Marx speaks of socioeconomic and historical laws as "natural laws." How can a socioeconomic and/or historical law supersede natural law and yet be a natural law? EvidentIy Marx defined "natural law" differently than others; or did he?

The dialectics of nature conditions, as a natural consequence of nature's processes, the negation of the laws of nature. Man is the negation; his instrument of negation is production (the tool through which control of nature is realized). Since the movement negating nature was inevitable, in the dialectical materialist and historical materialist perspective, and since transformational movement must naturally progress through ever higher stages of development, economic and historical laws are naturally derived, while simultaneously "supranatural." Thus, it may be fairly said that Marx did not deny the principle of natural law; merely that it eternally dominated man mechanically; indeed, that the truly inevitable natural movement to change led to a condition where man gained control of natural laws. Indeed, through production, society supersedes natural laws, "escapes" their sway, to find socioeconomic and historical laws, limited to a particular stage of production, replacing universal, necessary and eternal natural laws. (Also, the dominion of natural laws persists for all other life because only man has history and produces.) With this perspective, Marx could recognize an instinct of procreation where its meaning was instinct for sex relations and still maintain that it was inconsequential in the face of social production. Indeed, Marx could admit much concerning natural law and population and still deny its necessary, eternal sway over man. ${ }^{17}$ To do so would mean Marx's 
supposed general criticism of population was onitio 30

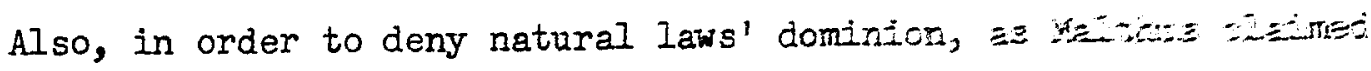

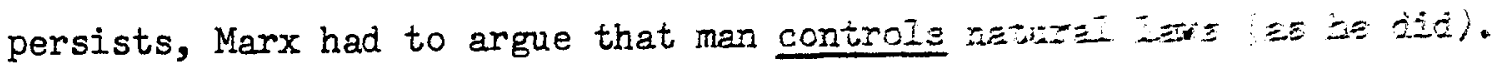

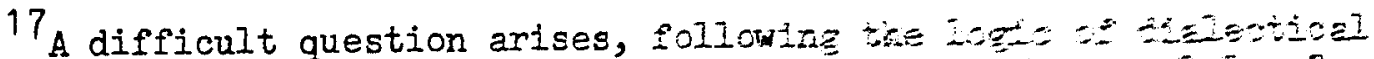
materialism. What is the negation of man's negatzor $=2.502=1$ Ian? This question opens a frightful can of worme whoh, ne:E -13012 other criticisms of Marx and Engels, this writer tatrks;

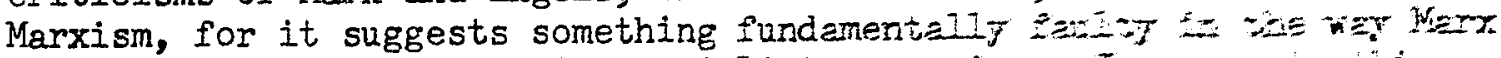
and Engels used dialectical materialist reazonize. It seys: 0 int

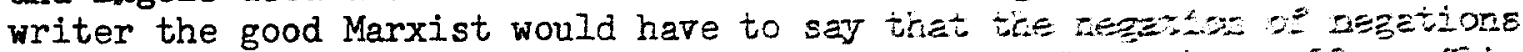

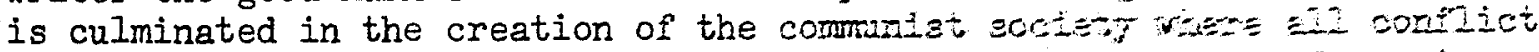

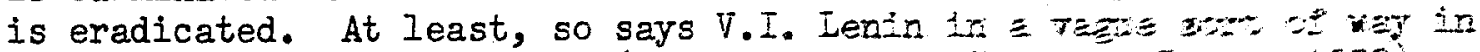

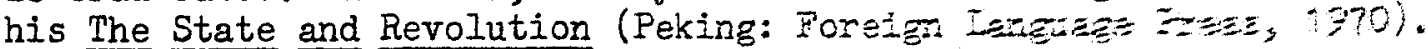

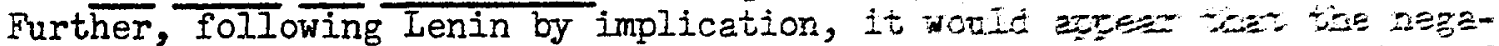

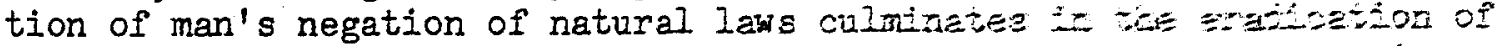
antagonisms between man and nature; no doubt dissolts ultimate conquest of nature.

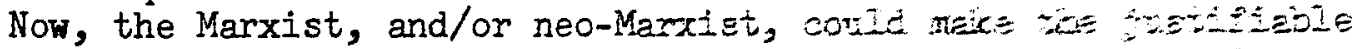
point that this writer's interpretation is merely ar In defense of attacks on communist society, it coric je $=000,00500$

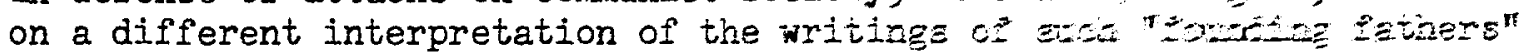

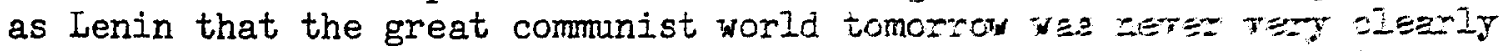

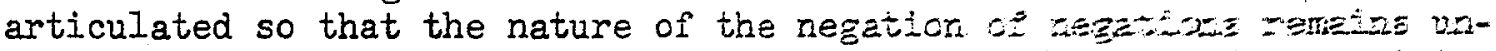
clear, uncertain. Thus, it could be argoed, beate de

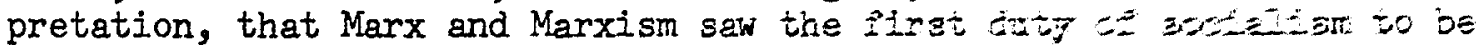

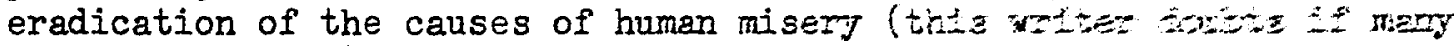
would doubt this). But the causes of happinese eppes we so jirerse

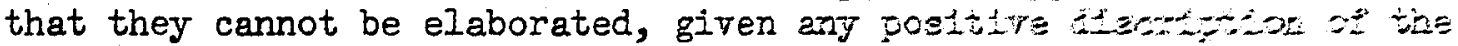

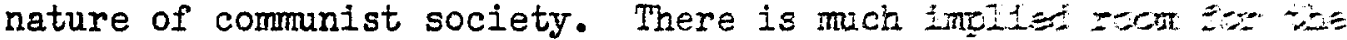
dialectical process, albiet at a level beyond tis netez:-

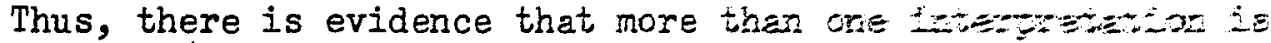

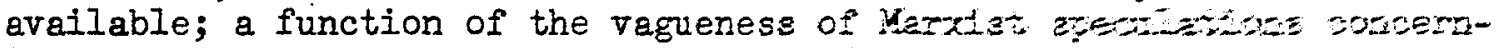

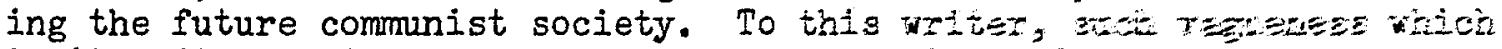
invites diverse interpretations is a critical protien.

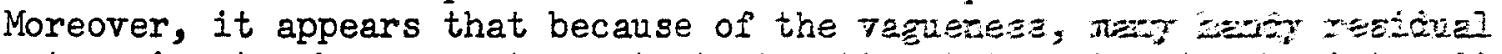

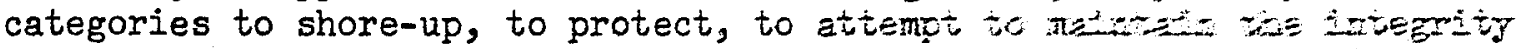

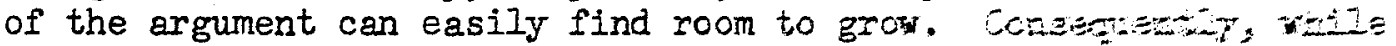

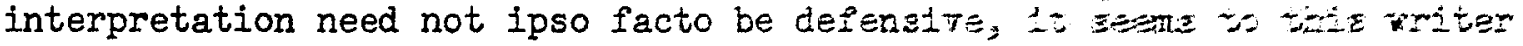
that it becomes defensive interpretation too easit.

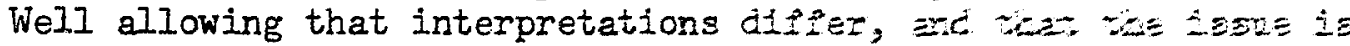
an open one this writer thinks a problem etili exise vits, of the interpretation employed, causes probleme $\mathrm{er}$ wercsm

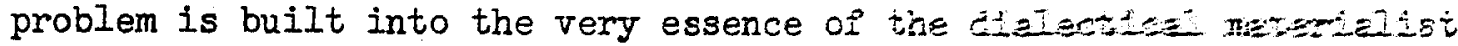

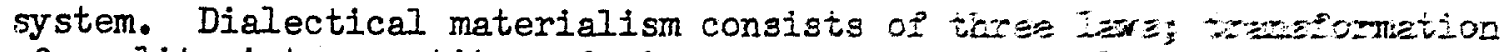

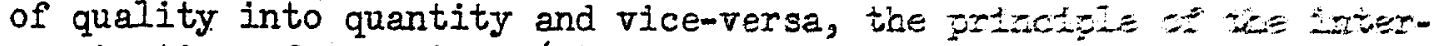
penetration of opposites (also called the unity of opers

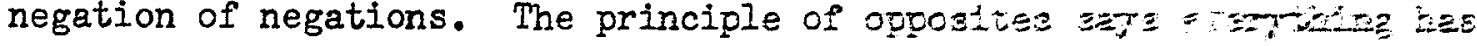


Looking at population, Marx attempted to show the socioeconomic laws which affected population, and succeeded in some degree in demonstrating the importance of social influences on population. However, the question arises, has man really controlled population processes under social production (in this case, either capitalism or socialism)? Procreation st1ll occurs as always. A geometrical growth rate is admitted (and no

an opposite. A look at the other laws reveals that they are propositions couched in the principle of opposites; the opposite of quantity is quality and vice-versa, the opposite of the negation is its negation (negation of negation). Thus, the application of dialectical materialism, to be done conzistently, compels focusing around the principle of opposites. Now, if everything has an opposite, how can there ever be a stage in human history where negations are all negated? The principle of opposites, if applied consistently, which lies at the heart of dialectical materialism, compels a negation to the "negation of negations." Therefore, the vague speculations of, in particular, Ienin, as well as Marx and Engels themselves in which a logical end to conflict is reached is not logically consistent with the essence of dialectical materialist reasoning. But to deny dialectical materialism is to deny Marxism.

At this point the different interpretations may be quickly invoked. "There is much implied room for the dialectical process, albiet at a level beyond the material." This writer asks: how can a Marxist speak of process beyond the material and be a Marxist? The essence of Marx's reasoning system, wholeheartedly backed up by Engels, is very clearly focused on materialism. So for this writer, while it must be conceded that the above is an important interpretation given mach support, it is a neo-Marxist interpretation; and for it to be operative and for dialectical reasoning to be maintained, the whole thrust of dialectical and historical materialism must be altered. While the end result may be a sizeable improvement on Marx, it would nevertheless be neo-Marxist. Marxism, this writer thinks, is caught in an inescapable bind via this critical problem for the heart of dialectical materialism. This criticism actually exceeds the purview of this study and really needs much more detailed elaboration. It was offered here because it is a problem that needs to be noticed and tackled. As a final point in this note: in response to the question, what is the negation of man's negation of natural laws? nature seems to be saying it is death for manl; witness the convergence of a multitude of probably insoluble ecological. problems which have been created by man's incessant efforts to "control natural laws." Thus, if the above did not suggest a critical problem which more or.less dooms Marxism, then nature's response to the Marxist (and capitalist) brand of progress will. 
articulation of whether growth may be slower, or whether it may be controlled, is advanced by Marx, except a brief implied suggestion that standard of living checks growth). Population's ultimate need for food is admitted, and persists. So what has been controlled? At best, an aspect of population processes has been affected, i.e. Iaborers depend upon the means of employment as much as or more than means of subsistence. At best, Marx has succeeded in demonstrating that the Malthusian check of misery, under special circumstances of capitalist accumulation, may stimulate increase and not check it (but Marx fails to generalize on the matter and so it remains unclear if misery always stimulates population increase). (Thus, again, it appears that Marx's views on population are far more specific than general.) And finally, the crème de la crème of the anomalie, Engels admits communist society might face a population problem. How has population been controlled?! What of the historically specific socioeconomic and historical laws if communism can have population problems much the same as capitalism (and probably as feudalism and ancient societies; if Marx read his history, as certainly he did, he saw ancient societies concerned with the same population problems as faced capitalism-on the one hand, what to do to increase population, and on the other hand, what to do in the event of overpopulation)? Now if Marx has not demonstrated that control of population by socioeconomic and historical laws supersedes natural laws, is his view superior to the normal perspective on natural law? Indeed, is there any difference at base? More generally, is it justified to regard Marx as a significant alternative theory of population? Thus, it can be seen that while a cursory reading of Marx gives 
the appearance serious decese, a dise exminerion of similarities and differences,

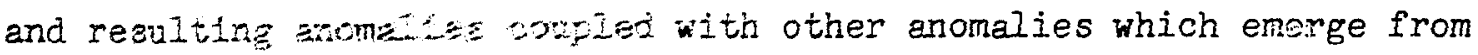
carefully lookse $2 \times$ Weanself: indicates that the relation of Marx to Malthus is most and and the tme nature of Marx's thought on

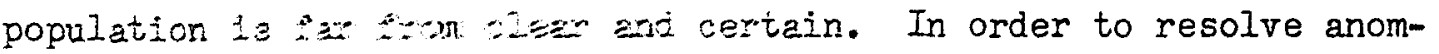

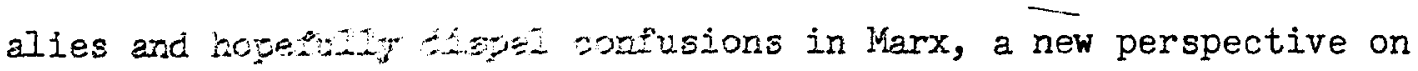
Marx is needed, nt.te xtese finally set, the next section must develop this persortiss.

IIE, A NI ZEEQEOTVE ON KAHX'S POPULATION THOUGHT

In this secter; E Der perspective on Marx will be advanced, resting heavily demographic thougt: smeting heretofore neglected. To do this, four subsectlone

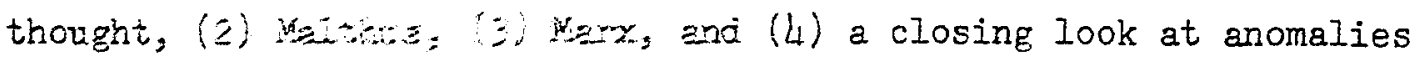
found in Marx.

Historicel Detelovnew z Eoviation Thought

While concen or popletion appears consistently the same over the cexturies, the $3 \%$ of it grows more extensive and complex with each century, Dha, teperods prior to post-mercantilist thought reflect single theres towtaes which did not very closely approach population then. Tye pormencentilist period, beneath the surface

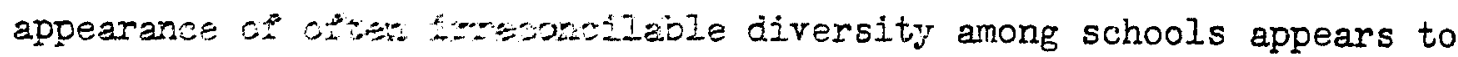

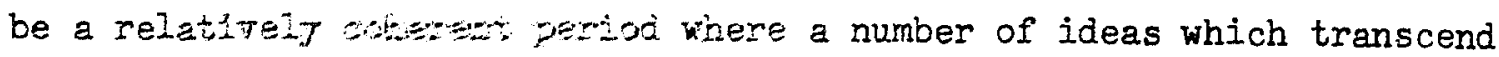
the differences anceg sobie form an evolving general view of 
population.

The most significant characteristic of virtually erezy witer prior to Malthus is that discussion of population eluage Poczeed on the question of population's role in the bullding of nationel wealth and strength, i.e. population was couched in an owerridinz scononic focus. This larger question, then, led to inquiries into reiatore of population to food supply, to international trade, to wages, or price of labor, to productivity, to the results of industrial and general economic growth, e.g. increases in the standard of liting, and laxary. This essential question was at the heart of debates oref the relative merits of agriculture or manufacturing as the econonic base of society, and its impact on population growth; also, affecting ins grestion of how much growth was best, i.e. is there an optimam popalizion size? The question of identifying the factors which encourages on discouraged population growth were also stimulated by this orerribing concern with increasing national wealth and strength; hence, also ths Etigupts to increase the precision and systematic quality of inguides through the application of quantitative tools was stimulated by thide overriding question.

With concern for increasing national wealth and Etrengti et the heart of post-mercantilist (and mercantilist for that $2 \mathrm{t} t \hat{\mathrm{N}} \mathrm{g}$ ) thought on population great strides were made in the stody of popolation. By the time of Malthus, a general set of conclusions appears wich all schools appear to accept; namely, that population tended to gror geometrically, checked by food supply, and virtueliy ETery preventive and positive check proposed by Malthus, that arailability of enployment, 
price of labor, and industrial and agricultural productivity affected population, and, finally, that statistics and methods resting on quantitative fact-gathering helped provide precise and systematic conclusions on population questions. Indeed, population was an element in economic considerations of substantial importance. Although such recognitions appeared extensive, the larger focus remained (a) concerned with the larger economic question of building national wealth and strength, (b) fundamentally emphasizing the integration of population into the larger economic concern, and (c) optimistic, believing in the merits and wisdom of populousness, on the one hand, and the bright future ahead of humankind on the other. Accordingly, it is true that nothing was left to Malthus to advance as an original idea concerning population. However, Malthus appeared and substantially influenced population thought. What was beneath the importance of Malthus?

\section{Malthus}

A fundamental shift in the focus of, and nature of, the study of population occurred with Malthus; first, he shifted the central concern of the study of population as a separate field of inquiry, and second, he made it an instrument of sociological and political-economic force. The result of Malthus' work was the removal of population from its place es an aspect of economic theorizing, and its full elevation to a cause for study as a subject in its own right. Malthus combined much of the quantitative work of the preceding two centuries in his essays; namely, Graunt, Petty, Price, and Sussmilch. He attempted to study population and draw conclusions based on analysis of facts gathered. Implicitly his efforts identified problems needing further study. 
Indeed, Malthus shifted population from doctrine to theory (and through theory set population on a footing of natural law, or biological determinism), and, though doing so in only a preliminary way, as Davis reveals, attempted to put study on a scientific footing. ${ }^{18}$ After Kalthus, population could not be dismissed by philosophers, political, social, or economic thinkers. True his work did not produce any fundamentally original conclusion on population, but Malthus does merit attention and recognition for contributing to the establishment of a science of demography.

If this were all Malthus did, he would probably be generally praised instead of generally controlversial. But on the way to such positive consequences Malthus also shifted concern over population from the larger economic issue of national wealth and strength to one focused on specific social problems, in particular, the social problem of poverty, and the larger social question of the future happiness of humankind. In the course of this second aspect of his shifting of the trendline of the development of demogiaphic thought, Malthus managed to contrive an argument against revolution, against blaming the capitalist class for the condition of the poor, and against a hopeful attitude toward future realization of utopias. These conclusions, recall, derived from subordinating socioeconomic forces affecting population to natural law, i.e. they were made secondary, intermediate, factors of limited significance which reinforced conclusions concerning the inevitability of poverty on the one hand, and the lack of hope for a 
better world tomorrow on the otiner hand.

Thus, with Malthus a fundamental shift (indeed a rather radical one) in the historical development of population thought occurred. The optimism of the preceding trendline was transposed into pessimism; the fundamental emphasis on population integrated into economic theory found population now a study of its own; and finally, the concern for national wealth and strength was dashed for a concern with the social problem of poverty and the social philosophic question of man's future happiness. Thus, in Malthus is found a significant, fundamental, rather radical shift in the trendline of the development of demographic thought despite the fact that no original concept or conclusion appeared in Malthus' theory of population.

$\underline{\operatorname{Mar} x}$

By looking at Marx in the sweep of the development of demographic thought and by recognizing the specific character of criticisms of Malthus, the intention, or purpose, of Marx's thought invites a new interpretation. First, from reading Marx, and his bibliographies, it appears evident Marx was extremely well read, aware of the thought of previous centuries and his own time. A phenomenal number of precursors to Malthus, and virtually every writer whose thought anticipates both Malthus and Marx appear in his footnotes and bibliographies; yet Marx's criticisms are not addressed to most of these writers, but to Malthus and a few parsons. Second, the 50 years between Malthus and Marx reflected a preoccupation with Malthas, i.e., the significant shift in the trendline of demographic thought perpetuated itself. Third, Marx's scope of analysis, i.e. his concern with the rise and fall of 
capitalism, and of the future nature of society, and his horizon of time-his analysis and background spans centuries-makes his avarenes: of trendlines superior. Keeping the above in mind, as well as the meny anomalies previously noted in Marx, a new perspective on Marx can be formed by viewing Marx as rejecting the wisdom of the trendline snifts perpetrated by Malthus. Furthermore, the new perspective will reaclve many of the anomalies noted in Marx.

By reviewing Malthus' work in the context of the historical development of demographic thought, it appears Malthus shifts the nature of population study such that his perspective is inconsistent with the longstanding trendline. A look at Marx's criticisms of Malthus in the context of this conclusion reveals that Marx's criticisms drive to the heart of points which produced this radical redirection of the trendline. First, Marx rejects elevating natural law (biological determinism) over socioeconomic factors affecting population, i.e. the making of population a clear-cut independent variable. Hence, his effort to challenge the notion of natural law by (1) offering an alternative perspective on natural law, (2) denying the principle of diminishing returns, (3) emphasizing the institutionalized economic power of the means and relations of production over population, $i . s$. the demands of capitalist accumulation and the normal operation of capitalist production, affecting its age and sex structure, migration, mortality rates, and rate of growth.

Second, Marx, as a corollary to the first point, challenges the significance of de-emphasizing socioeconomic affects on population. Accordingly, Marx advances the view that employment, price of labor, 
and, implicitly, standard of living have critical impacts on population growth. Furthermore, he argues that production keeps pace with growth, that diminishing returns problems are fallacicus, that ill-consequences of population growth are not inexorable, inevitable, necessary; but are socially derived conditions.

Third, he substantially challenges utilizing population to explain poverty, i.e. he rejects the shift to emphasis on specific social problems. Thus, he attempts to provide an alternative explanation for (1) misery, and (2) consequences of misery; accordingly, misery appears a function of the economic system, and its consequences the stimulation, not the checking, of population growth. Furthermore, the result of Marx's efforts reveals Marx attempting to prove population is integrated into larger economic questions, i.e. that it is a dependent variable, and that specific social problems are best analysed in, essentially, a broader socioeconomic approach.

Finally, Marx's arguments reject Malthus' pessimism. The thrust of his criticisms argue for a bright future for human society. Marx reiterates the optimistic perspective, and, by implication, a more favorable view of the merits of populousness than found in Malthus; the result of which is a redirecting of the issue away from concern for the happiness of man to realization of man's socioeconomic destiny as the angle of emphasis. With Marx convinced of a bright future and eventual culmination in the communist society, and his focus on large scale social change, involving colossal economic processes, it appears Marx's attempt is to redirect the focus to one consistent with concern for national wealth and strength; although clearly Marx's emphasis is 
oroader than this, though, this writer thinks, consistent with its tinnist.

Thus, on closer examination in a historical perspective, Marx's population thought appears consistent with the flow of the one or two century trendline radically altered by Malthus. Thus, Marx's thought appears as an effort to correct the shift, to re-establish the continuity of the trendline. Ithis conclusion is further reinforced by looking at points where Marx appears to agree with precursors of Malthus and Kalthus himself (or where, taking the above view, it would follow that he would do so). Marx does not deny the notion of an innate passion between the sexes, nor of the check to population increase of Iinits to food supply (recognized by Ortes, Young, Price, Smith, lecker, most all mutually anticipating Malthus and Marx, and most later 18 th century writers). He essentially agrees with prevailing conclusions concerning the power of employment, price of labor, and exploitation of labor to affect population (which Smith, Necker, Herrenschwand, and others agreed upon). He does not challenge the notion of geometrical growth rates of population (upon which virtually all precursors of Kalthus agreed, and especially Ortes, Price, and Petty, whom Karx studied carefully). Further, Marx does address some important detail points in demographic study, e.g. Why the discrepancy in $\varepsilon \subseteq 7$ ratios favoring females in the laboring class? and why the high birti rates in the laboring class? Finally, the fact that Marx did not include all precursors of Malthus in his critique of Malthus and his Poliowers (i.e. precursors and contemporaries) suggests that, as noted, Marx was not opposed to, bui supportive of the trendline of 
demographic history radically diverted by Malthus.

Re-examining Anomalies in Marx

If Marx is viewed in the larger sweep of the development of demographic thought, the anomalies in his population thought are substantially explained. Questions concerning the numerous points of agreement and questions concerning failure to attack critical elements of Malthus, e.g. Malthus' postulate contending stimulation to growth as innate, are explained by looking at Marx as accepting the trendline of population thought before Malthus. Those points where Malthus' thought overlaps the trendline, is consistent with it, appear undisturbed by Marx. Thus Marx does not attack the notion of preventive and positive checks, but specific deviations from the trendline, e.g. utilization of the notions to rationalize poverty. This would explain why Marx did not criticize Malthus more systematically. Further, he stopped his criticism where he did because it covered the points conditioning the radical change in the direction of the trendline of development of demographic thought. He challenged the person and not the entire theory because he felt that Malthus had maligned and misused thought for ulterior reasons. Thus, as well, the critique of Malthusians is far more specific than has previously been thought; the Malthusian was a parson, an apologist, and shifting the trendline of thought with an ulterior motive in mind, and in a direction that was inconsistent with previous development. This conclusion is reinforced when it is remembered how Marx praised the significant pre-Malthusian Ortes, and studied the precursor of Malthus and himself, Necker.

By looking at Marx in a historical context, it appears his 
thought was not a theory of population. First, he did not articulate a theory because this was not his purpose. Second, his was not a theory of population because his thought fits into an already existing theoretical structure which had evolved prior to Malthus. Thus, his efforts amount to (1) attempts to revitalize this theoretical structure vis-a-vis Malthusianism, and (2) to contribute to its development; witness his few but substantial attempts to explain high birth rates and mortality rates among the laboring class and the discrepancy favoring females. Thus, if he was not writing a theory of population, it explains, somewhat, why he did not elaborate thought on population for other stages in the development of production, e.g. feudalism and/or socialism.

Clearly, then, by looking at Marx in a broad historical context, it appears that there is no justification in looking to Marx as a basis for an alternative theory of population to that of the West, for Marx was far more integrated in the development of population theory than has previously been realized. Marx was not writing a theory of population to act as an alternative to Malthus or others, but was merely trying to prevent continuation of a radical change in the trendline of the development of population thought inconsistent with the more generalized focus of population which had evolved prior to Malthus.

\section{TV. REMAINING PROBLEMS NITH MARX}

While a broad historical look at Marx's population thought revealed some interesting new angles on Marx and resolved some hidden anomalies, it did not resolve all problems with Marx. Some logical 
problems exist on two fronts; (1) questions arise regarding reasoning with the concept of natural law, and (2) problems exist because Marx is locked into a particular view of process. On the first front, his view of natural law suffers because (1) it appears, at base, to be essentially the same as other views, (2) he can provide no criteria for determining how, or when, or of what extent economic and historical laws supersede natural laws, and (3) his view rests on the dialectical materialist framework which appears to have some inherent inconsistencies, i.e. the principle of opposites makes the claimed operation of the negation of the negation in terms articulated by Marxists incorrect. This, in turn, causes problems for the Marxist concept of natural law, considering that it is based on dialectical materialist thinking. On the second front, Marx's reasoning system Iocks him into a pro-growth and only pro-growth position. His analysis of population, indeed his analysis in general, is consequently handicapped because under such a lock, he cannot argue for control of population; only the keeping of the pace of production equal to or above the rate of population increase. Also, under his reasoning system, it is really not possible to see population as a serious specific social problem because of the integration of population into larger economic theory which (1) views population as a dependent variable which need not be a problem under appropriate production, and (2) concludes it is therefore incorrect to consider population a problem per se. Thus, viewed in Marxian eyes, it is difficult to admit certain facts, conditions, and problems of population.

Some problems of validity of reasoning and concepts exist also. 
The following points are involved: (1) the notion of special economic and historical laws, (2) the indefinite extensibility of production, and (3) the related problem of diminishing returns. Regarding the first point, Marx can be criticized for a fallacy in his reasoning on the matter of special economic and historical laws. First, Marx establishes no criteria for determining the boundaries of such special laws. Second, Marx presunes soil fertility can be indefinitely extended, and industrial and agricultural production also fit this pattern. If so, it implies an extensibility that extends beyond the boundaries of particular historical periods, thus revealing conditions which transcend particular historical stages in the development of production. Again the question: where are the criteria which would explain how special laws may persist over more than one special stage of development? Finally, with regard to population, Marx says that each historical period treats population differently (this is stated both explicitly and implicitly). While he makes no substantive comments about other periods, he does imply that only in the capitalist period does overpopulation occur. By doing so, from inference, it may be concluded that Marx sees population treated differently for different periods. But the record shows that throughout history, the same patterns of behavior have been employed to deal with population; overpopulation was a concern of the Greeks as well as the 17th century English and French; techniques to encourage growth were found in Greece and Rome which were employed by mercantilist govemments; from the Greeks forward, contraception, abortion, infanticide, euthanasia have been the same for all civilizations. While true that these are specific components concerning population, 
thus different from concern for overpopulation which more or less integrated these components in treatments by Malthus and Marx, when looked at as a whole, it reflects three points: (1) that the same matters concerned humankind at least since the Greeks, namely, growth, overpopulation, population control techniques, (2) that while clearly not a main issue, as it was for Malthus and Marx, overpopulation was given thoughtful attention, and (3) over time, the development of thought reflects a trend of movement from diverse concerns for specific components of the large question of population discretely considered to a more or less general concern for several components in one larger theoretical perspective. Consequently, Marx's position does not appear to have the support of history.

The second point deals with the assurption that production is indefinitely extensible (in a fixed space, with limited land and finite resources). Marx's assumption hinges on the principle of diminishing returns being false and fixed land being able to support indefinite increases in yield per acre. Living at the edge of the closing quarter of the 20th century, such presumptions are entirely unacceptable. On the one hand, the empirical evidence for Marx's view is ouite insignificant, and on the other hand, the mass of evidence continues to increase supporting the view that all forms of growth are limited. The third point is actually an aspect of the second. Farx denies the validity of the principle of diminishing returns. Karx's criticism of Malthus substantially hinges on the ralidity of his rejection of this principle. However, diminishing returns have been well documented and cannot be denied. It is unrealistic to deny them; 
an error here in Marx which amounts to a large puncture in his argument.

Fourth, in both Malthus and Marx, there is a failure to support empirical propositions with experimental, or substantially verifiable, evidence. Marx's conclusions on population afford no conclusive evidence, experimental or empirical, which lend support to his view. Thus, acceptance of the Marxist position must be made as an act of faith; as a belief in a promise for future significant scientific revelations, when existing conclusions were reached without experimental or empirical science playing a very significant role.

Finally, Marx suffers in the area of population by writing in a manner which invites confusion, uncertainty, and misinterpretation. His population thought is not systematically advanced, is incomplete, and generally nontheoretical. This writer thinks Marx does not articulate his population thought with enough attention to the way he expressed himself, resulting in the reader having to live with unclear meanings and intentions, e.g. was he being metaphorical or literal in use of the term "instinct of propagation?" These points are quite important for understanding Marx, but Marx uses such terms almost casually. Indeed, such ambiguity has no doubt lent itself to Marxists being able to see the articulation of an alternative theory of population which really was never intended to be there in Marx's text.

As Donald Bogue notes in the introduction of his textbook, Principles of Demography, (New York: John Wiley, 1966), modern demography would be better off dismissing both Malthus and Marx for neither advanced the science of demography very far. This study agrees with Bogue in one respect. It has shown that theoretically the 
thought of both MaIthus and Marx leaves much to be desired as bases for building a scientifically exact theory of population. This writer agrees with Bogue that demography would be better served by dispensing with the Marx-Malthus debate and getting on with the business of developing scientific emographic theory. However, the world presently is not in a position to dispense with the Marx-Malthus debate or either writer's preliminary work contributing to the development of demographic theory. The present world forms two great bodies of thought contending for dominance and Marx and Malthus are considered focal forefathers. If anything, their importance is increasing at the present time. Thus, Marx and Malthus remain very important, and to have a thorough understanding of the modern debate, neither writer can be dismissed, but must be carefully studied. This study, hopefully, has proved this to be so and has provided the careful study needed. 
CHAPTER VI

CONCLUSION

The purpose of this siudy was to look critically at one of the fundamental contentions of modern Marxists; namely, that Marx can be looked to as the isse, or root, of an alternative theory of population. The question was, was Karx writing a theory of population? It served as the prime question for organizing a re-examination of Marx.

To achieve the goals of this study, four main chapters were developed; a presentation of the historical development of demographic thought, of $\mathrm{M}_{\mathrm{al}}$ thus' thought, of Marx's thought, and a new perspective on Marx which utilized the development of demography as a principal feature,

The new perspective on Marx which emerged revealed that (1) Marx was not witing a thecry of population, but merely challenging points which were key features of a rather radical shift of the trendline of development of demographic thought advanced by Malthus, and (2) by looking at Marx in this context, Marx appears quite corisistent, with the trendline of developments prior to Malthus (which, recall, was quite "Malthusian" in character). Thus, it appears that Marx was far more a Malthusian than has been thought, and his attack on "Malthusians" was far more specipic tian thought; involving a specific, not a general, attack on Malthos, his parson cohorts; and those who would use population as ar apology for the excesses of capitalism. Accordingly, 
it was concluded that Marx does not suffice as a justifiable base, or root, for a supposed alternative theory of population as the modern Marxists claim. Indeed, to make Marx consistent with this place in the development of demographic thought would be to integrate him into the trendiines which have culminated in the present Western position. If modern Marxists followed Marx in the above manner, this writer thinks the present differences between Marxists and the West on population would be mich smaller, if existent at all.

If this is not adequately convincing, a look at the incomplete, amgibuous, unclear structure of Marx's population thought, taken in itself, and the internal problems with it, steming from his problematical view of natural laws, his use of dialectical materialism, his view of diminishing returns, and his lack of empirically, or experimentally, testable propositions makes Marx's thought a very unsatisfactory basis for an alternative theory of population which is supposed to be superior to its rival.

Thus, the modern Marxists cannot win on two counts: (1) Marx reconsidered in the flow of demographic history reveals his thought is highly consistent with its "Malthusian" trendline, and (2) Marx, taken by himself, is inadequate as a basis for a theory of population. 


\section{REFERENCES}

\section{CHAPTER I: INTRODUCTION}

The World Population Problem

"As Famine Spreads-What's To Be Done." U.S. News and World Report, 18 Nov. 1974, pp. 87-90.

Borgstrom, Georg. The Hungry Planet. New York: Collier Books, 1972.

Coale, Ansley J. "The History of the Human Population." Scientific American, Sepetember 1974, pp. 40-51.

Davis, Kingsley. "Population Policy: Will Current Programs Succeed?" in Michael Micklin. Population, Environment, and Social Organization: Current Issues in Human Ecology. Hinsdale, Ill.: The Dryden Press, 1973, pp. 352-76.

Freedman, Ronald and Bernard Berelson. "The Human Population." Scientific American, September 1974, pp. 30-39.

Pradverand, Pierre. "International Aspects of Population Control." Concerned Demography, II, No. 2, December 1970, 1-16.

Report of the Secretary-General. "Report on the Second Inquiry Among Governments On Population and Development." Item 3 of the Provisional Agenda of the World Population Conference, 1974. United Nations Economic and Social Council. Population Commission, Third Special Session, 4-15 March 1974. New York. E/CN.9/303.

Spengler, Joseph. Population Change, Modernization, and Welfare. Englewood Cliffs: Prentice-Hall, Inc., 1974.

Watt, Kenneth E.F. The Titanic Effect. Stamford, Conn.: Sinauer Association, Inc., 1974.

The World Food Situation and Prospects to 1985. U.S. Department of Agriculture. Economic Research Service, Foreign Agricultural Report No. 98. 
Modern Marxist Views

General Background

Lenin, V.I. Imperialism, The Highest Stage of Capitalism. Peking: Foreign Languages Press, 1970.

- Materialism and Empirio-Criticism. Peking: Foreign Languages Press, 1972 .

Quotations from Chairman Mao Tsetung. Peking: Foreign Languages Press, 1972.

Selected Readings From the Works of Mao Tsetung. Peking: Foreign Languages Press, 1971 .

Stalin, J.V. The Foundations of Leninism. Peking: Foreign Languages

V.I. Lenin Selected Works. New York: International Publishers, 1971. USSR

Bzhilianskii, Iu. "Political and Economic Problems of Population Under Socialism." Voprosy ekonomiki, 1972, No. 10. Trans. in Problems of Economics, XV, No. 12, April 1973, 52-72.

Galetskaia, R. "Socioeconomic Problems of Population." Voprosy ekonomiki, 1972, No. 3. Trans. in Problems of Economics, XV, No. 5, September 1972, 43-50.

Larmin, 0.V. "On General and Specific Laws of Population." Vestnik moskovskogo universiteta, seriia VII, Ekonomika, 1971, No. 5. Trans. in Problems of Economics, XV, No. 2, June 1972, 3-23.

Ryabushikin, Timon. "USSR: population and development." Moscow News, 24-31 Aug. 1974, pp. 10-11.

Valentei, D. "Current Population Problems in the USSR." Nauchnye doklady vysshei shkoly-ekonomicheskie nauki, 1969, No. 1. Trans. in Problems of Economics, XII, No. 7, November 1969, 49-66. $\underline{\text { PRC }}$

"China Explains Her Views on the Population Question." Peking Review, 30 April 1973, pp. 16-17.

"China's Views on Major Issues of World Population." Peking Review, 30 August 1974, pp. 6-9. 
"China's Views on Solplag ine worid Zood Problem." Peking Review, 15 Nov. 197L, pp. 9-12.

"Chinese Observer on Popizetion Restion." Peking Review, 7 Dec. 1973, pp. 10-i1.

"Family Planning Gains Foprianty." Peking Review, 20 Sept. 1974, pp. $17-18$.

Feng Nien. "How China Scived ̈̈er Zood Problem." China Reconstructs. XXIV, No. 1, Jarwary i975, pD. 2-6.

Kuo Huan. "Accent on Zrrirorurentei Protection." Peking Review, 8 Nov. 1974, po. 9-11.

Wang Ya-nan. NThe Mertict Popoietion Theory and China's Population Problem." Chineze Econosec Studies, II, No. 3-4, Spring-Summer $1969,3-91$.

CHAPTER II: THE DETZIOENOUR OZ DEIOGRAPHIC THOUGHT

Eonar, Janes. Theories of Zogolation from Raleigh to Arthur Young. New York: Aagazt, $Y$. Yelly, Bookseller, 1966.

Department of Social LPiara, Popnlation Division. "The Determinants and Consequences of Ectaiztion Trends, A Summary of the Findings of Studies on the Eeletionships between Population Changes and Economic and Socti Concitions." Population Studies, No. 17. New York: United MEtzone, 1953.

Spengler, Joseph J. Zrenci Ersdecessors of Malthus. New York: Octagon Book8, 19li2.

Stangeland, Charles Edi. Exe-Helthosian Doctrines of Population. New York: The CoLrubie Tniversity Press, 1904.

CHAPTER III: MaITHUS

Beales, H.L. "The Fitsoridas Context of the 'Essay' on Population," in D.V. Glass, Ed, Introanction to Nilthus. New York: John Wiley and Sons, Inc., 19:3.

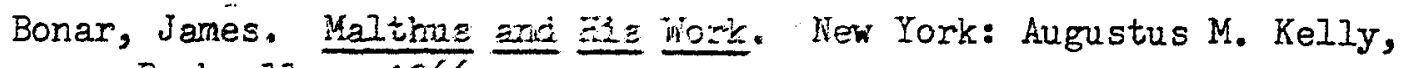
Bookseller, 1966 .

Cook, Robert C. Ed. Maitras in Eetrospect: The Stork Visits Dorking1766." Population Dzidetin, YXII, INo. 1, February 1966, 1-27. 
Davis, Kingsley. "Malthus and the Theory of Population," in Paul I. Lazarsfeld and Morris Rosenberg. The Language of Social Research. GIencoe: The Free Press, 1955, pp. 540-53.

Eversely, D.E.C. Social Theories of Fertility and the Malthusian Debate. Oxford: The Clarendon Press, 1959.

Flew, Anthony. Ed. Malthus: An Essay on the Principle of Population. Hammondsworth, Middlesex, England: Penguin Bocks, Ltd., 1970.

Griffith, G. Talbot. Population Problems of the Age of Malthus. 2nd ed. New York: Augustus M. Kelly, Bookseller, 1967 .

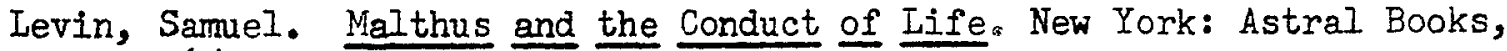
1965.

Malthus, Thomas Robert. An Essay on the Principle of Population or A View of its Past and Present Effects On Human Happiness, with An Inquiry into our Prospects Respecting the Future Removal or Mitigation of the Evils Which it Occasions. 7th Ed. London: Reeves and Turner, 1872 .

McCleary, G.F. The Malthusian Population Theory. London: Faber and Faber, Ltd., 1953.

Spengler, Joseph J. "Malthus's Total Population Theory: A Restatement and Reappraisal." Population Economics: Selected Essays of Joseph J. Spengler. Durham: Duke University Press, 1972, pp. 3-65.

Toynbee, Arnold. The Industrial Revolution. Boston: Beacon Press, 1968.

CHAPTER IV: MARX

Bottomore, T.B. Ed. Karl Marx: Selected Writings in Sociology and Social Philosophy. New York: McGraw-Hill Book Co., 1964.

- Karl Marx Early Writings. New York: McGraw-Hill Book Company, 1964 .

Engels, Frederick. Dialectics of Nature. New York: International Publishers, 1940. Duhring). New $\frac{\text { Herr }}{\text { York }} \frac{\text { Eugen }}{\text { International }} \frac{\text { Duhing's }}{\text { Publishers, }} \frac{\text { Rution }}{19} \frac{\text { Science (Anti- }}{39}$ State. New York: $\frac{\text { The }}{\text { International }} \frac{\text { of the Family, Private Property, and The }}{\text { Pablishers, 1942 }}$

Marx, Karl. Capital, vols. I \& III. New York: International Publishers, 
Meek, Ronald I. Ed. Marx and Engels on the Population Bomb. Berkeley: Ramparts Press, 1971.

Petersen, William. "Marx versus Malthus: The Men and the Symbols," in Kenneth C.W. Kammeyer, ed., Population Studies: Selected Essays and Research. Chicago: Rand McNally and Co., 1969.

Veblen, Thorstein. "The Socialist Economics of Karl Marx and His Followers." The Place of Science in Modern Civilization and Other Essays. New York: Russell and Russell, 1961, pp. 409-56.

CHAPTER V: A NEW PERSPECTIVE ON MARX'S POPULATION THOUGHT

Kuhn, Thomas S. The Structure of Scientific Revolutions. 2nd ed. Chicago: The University of Chicago Press, 1970. 
APPENDIX

PRINCIPAL WRITERS AND SUBJEIT AREAS OR FACTORS

RELATED TO POPULATION THEY NOTED IN THE

DEVELOPMENT OF DEYOCRAPHIC

THOUOHT BEFORE MALTHUS,

\begin{tabular}{|c|c|c|c|c|c|c|c|}
\hline Chronolon & Mathematics & $\begin{array}{c}\text { Standard of } \\
\text { Living }\end{array}$ & $\begin{array}{c}\text { Geometrical } \\
\text { Growth }\end{array}$ & $\begin{array}{l}\text { Limited Food } \\
\text { As A Check, }\end{array}$ & $\begin{array}{r}\text { Positive } \\
\text { Cnecks }\end{array}$ & $\begin{array}{l}\text { Enployment } \\
\text { and Wages }\end{array}$ & Poverty \\
\hline $\begin{array}{l}\text { Grapks \& } \\
\text { Fomans }\end{array}$ & & & & $\begin{array}{l}\text { Plato } \\
\text { Arlstotle }\end{array}$ & $\begin{array}{l}\text { Plato } \\
\text { Arlstotle } \\
\text { Greek City- } \\
\text { States } \\
\text { Ronan Enofre }\end{array}$ & & \\
\hline \multicolumn{8}{|l|}{$\begin{array}{l}\text { Early } \\
\text { Cnristian }\end{array}$} \\
\hline \multicolumn{8}{|l|}{ Montieval } \\
\hline $\begin{array}{l}\text { Wercan- } \\
\text { tilist }\end{array}$ & $\begin{array}{l}\text { Conflnf: } \\
\text { fraunt } \\
\text { fale } \\
\text { fetty }\end{array}$ & $\checkmark$ & $\begin{array}{l}\text { Sraunt } \\
\text { Hale } \\
\text { Petty } \\
\text { Ralelgh } \\
\end{array}$ & $\begin{array}{l}\text { Graunt } \\
\text { fale } \\
\text { Potty } \\
\text { Ralo1gh }\end{array}$ & $\begin{array}{l}\text { Graunt } \\
\text { Hale } \\
\text { Potty } \\
\text { Rolelah }\end{array}$ & & Alcock \\
\hline $\begin{array}{l}\text { gre- } \\
\text { telthusians }\end{array}$ & $\begin{array}{l}\text { Chalmars } \\
\text { Ealey } \\
\text { Erice } \\
\text { Fusmilch }\end{array}$ & $\begin{array}{l}\text { Cantilion } \\
\text { Melon } \\
\text { Montesquien } \\
\text { Adam SmIth }\end{array}$ & 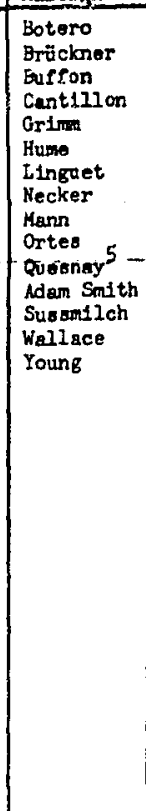 & 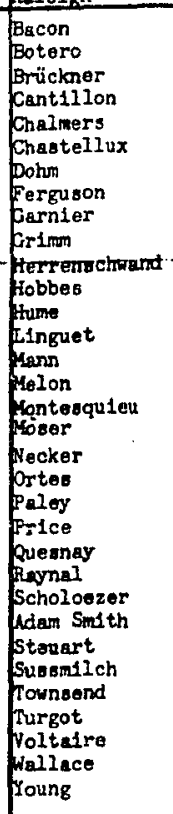 & 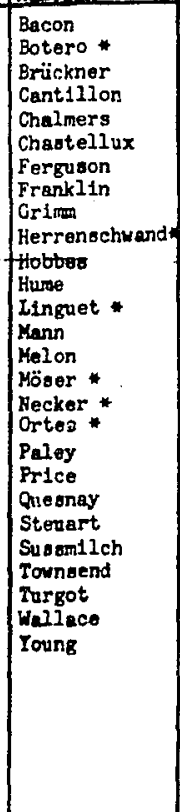 & $\begin{array}{l}\text { Cantilion } \\
\text { Helvótou } \\
\text { Herrenschwand } \\
\text { Law } \\
\text { Necker } \\
\text { Adam Smith } \\
\text { Young } \\
\end{array}$ & $\begin{array}{l}\text { Adam Sm1th } \\
\text { Townsend } \\
\text { Turgot }\end{array}$ \\
\hline Pre-Merxian & & $\begin{array}{l}\text { Cantilion } \\
\text { Chastellux } \\
\text { Grimm } \\
\text { Linguet } \\
\text { Necker } \\
\text { liam Smlth }\end{array}$ & & & $\begin{array}{l}\text { Petty } \\
\text { Wallace }\end{array}$ & $\begin{array}{l}\text { Cantilion } \\
\text { fond1liac } \\
\text { farnier } \\
\text { Herrencshw and } \\
\text { Einguet } \\
\text { Necker } \\
\text { Quesnay } \\
\text { Adan Sint th } \\
\text { Steuart } \\
\text { Turgot } \\
\text { Young }\end{array}$ & $\begin{array}{l}\text { Grimin } \\
\text { Linguet } \\
\text { Necker }\end{array}$ \\
\hline
\end{tabular}


NOTES FOR APPENDIX

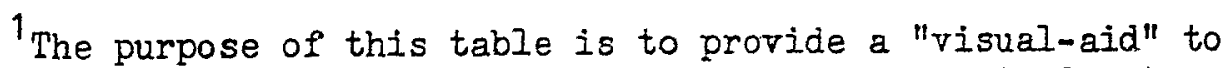
discussion of the development of demographic thought in Chapter II. The columns of the table represent subject areas and factors studied as relationships to population. The colums are not all-inclusive, i.e. they represent the most widely considered subject areas and factors. Names of writers are employed when individuals made significant contributions. In the case of Early Christian and Kedieval periods, no significent individual writers could be identified. In the case of the Mercantilist period, checks ( $)$ are used to identify subjects considered by mercantilist writers because there were a plethora of individual writers essentially saying the same things. Names are used to refer to Mercantilist writers only when they really stand apart from the group. Names are used in Pre-Malthusian and Pre-karxian sections because these two sections are essential to this study. Where no discussion of a subject area is foffered by a period or group, the space is left blank.

2Limits of food as a check is separated from positive checks because in some cases individual writers recognized food as a limit but did not go into discussion of food as one of many other positive checks. Also, some discussed positive checks but did not stress limits of food as a serious, or crucial, check.

${ }^{3}$ Names with asterisks after them were individual writers who also recognized Malthus' preventive checks as well as positive checks.

${ }^{4}$ Cantillon's name is used to refer to both his work and to the work of his followers. Only when a follower advanced significant other ideas or deviations from Cantillon is he listed under his own name.

5 Quesnay's name is used to rejer to both his work and physiocrats and their ideas in general. Only when an individual physiocrat other than Quesnay made a significant contribution is his name listed. 